\title{
30- "[B]en gözlerimle dinlerken”: Tevfik Fikret’in şiirlerinde edebî sinestezi ve bir edebî sinestet olarak Tevfik Fikret
}

\section{Gülsün NAKIBOĞLU 1}

APA: Nakıboğlu, G. (2021). “[B]en gözlerimle dinlerken”: Tevfik Fikret’in şiirlerinde edebî sinestezi ve bir edebî sinestet olarak Tevfik Fikret. RumeliDE Dil ve Edebiyat Araştırmaları Dergisi, (25), 468-504. DOI: 10.2900o/rumelide.1036573.

$\ddot{\mathbf{O z}}$

Bu makalenin temel amacı Tevfik Fikret'in üslûbunun önemli bir unsuru olan edebî sinesteziyi şiirlerinden hareketle sinestetik metaforlar bağlamında farklı boyutlarıyla ele almak ve şairin bir edebî sinestet olarak edebî sinesteziden şiirlerinde faydalanma biçimlerini, edebî sinesteziyi kullanma amaçlarını tespit ederek ortaya koymaktır. Öncelikle onun şiirlerindeki sinestetik metaforların türleri belirlenmektedir. Sinestetik metaforların temel olarak üç farklı türü ele alınmaktadır: yüksek sinestezi ve düşük sinestezi (güçlü ve zayıf sinestezi). Tevfik Fikret’in şiirlerindeki edebî sinestezinin gelişim seyrini takip etmek ve edebî sinesteziyi hangi etkiler dahilinde şiirlerinde kullanmaya başladığını belirlemek üzere şairin şiirleri üç ayrı dönemde ele alınmaktadır. Her üç dönemde de üç farklı türde tespit edilen sinestetik metaforlar ayrı başlıklar altında verilmektedir. Edebî sinestezinin hangi duyular arasında ya da hangi kaynak ve hedef duyulara yöneldiği tespit edilerek Ullman'ın duyular hiyerarşisi doğrultusunda bu tercihin genel hususiyetleri ve onun şiiriyle örtüşen yönleri açılanmaktadır. Tevfik Fikret’in özellikle Rübâb-ı Şikeste döneminde, katmerli sinestezi yöntemini kullanmayı tercih ettiği tespit edilmektedir. Bu yöntem birer edebî sinestet olan Tevfik Fikret ve Servet-i Fünûn şairlerinin edebî sinestezi alanına özgün bir katkısıdır. Katmerli sinestezinin Fikret’in şiirlerinde iki türü belirlenmektedir: birlikte aktarım ve dolaylı zincirleme aktarım. Tevfik Fikret'in şiirlerinde edebî sinesteziyi yoğun duygusal etkiler oluşturmak üzere bilinçli bir şekilde kullandığı Tsur'un edebî sinestezi yaklaşımından istifadeyle makalede gösterilmektedir. Bir Servet-i Fünûn şairi olan Tevfik Fikret’in edebî sinesteziye özgün katkıları ve şairin şiirinde edebî sinestezinin önemli işlevleri tespit edilmektedir. Sonuç olarak Tevfik Fikret'in bir edebî sinestet olarak genel tavrı ve şiirlerinde kullandığı edebî sinestezinin özellikleri ortaya konulmaktadir.

Anahtar kelimeler: Tevfik Fikret, Servet-i Fünûn, edebî sinestezi, sinestetik metafor, duyular hiyerarşisi, düşün-duyum

\section{"When I was listening by my eyes": literary synaesthesia in Tevfik Fikret's poetry and Tevfik Fikret as a literary synesthete}

\begin{abstract}
The main purpose of this article is to deal with literary synesthesia, which is an important element of Tevfik Fikret's style, with different dimensions in the context of synesthetic metaphors, based on his poems, and to reveal the poet's ways of using literary synesthesia as a literary synesthete in his poems, by identifying the purposes of using literary synesthesia. First of all, the types of synesthetic metaphors in his poems are determined. There are basically three different types of synesthetic
\end{abstract}

Dr. Öğr. Gör., İstanbul Teknik Üniversitesi, Türk Dili Bölümü (İstanbul, Türkiye), nakiboglu@itu.edu.tr, ORCID ID: oooo-0003-0973-7589 [Araştırma makalesi, Makale kayıt tarihi: 11.11.2021-kabul tarihi: 20.12.2021; DOI: 10.29000/rumelide.1036573]

Adres
RumeliDE Dil ve Edebiyat Araştırmaları Dergisi Osmanağa Mahallesi, Mürver Çiçeği Sokak, No:14/8 Kadıköy - ISTANBUL / TÜRKIYE 34714 e-posta: editor@rumelide.com tel: +90 $5057958124,+902167730616$
Address

RumeliDE Journal of Language and Literature Studies

Osmanağa Mahallesi, Mürver Çiçeği Sokak, No:14/8

Kadıköy - ISTANBUL / TURKEY 34714

e-mail: editor@rumelide.com

phone: +90 5057958124 , +90 2167730616 
metaphors: high synesthesia and low synesthesia (strong and weak synesthesia). Tevfik Fikret's poems are discussed in three different periods in order to follow the developmental course of literary synesthesia in his poems and to determine under which effects he started to use literary synesthesia in his poems. Synesthetic metaphors identified in three different types in all three periods are given under separate headings. By determining between which senses or which source and target senses literary synesthesia is directed towards, the general characteristics of this preference and its overlapping aspects with his poetry are explained in line with Ullman's hierarchy of senses. It is determined that Tevfik Fikret preferred to use the layered synesthesia method especially during the Rübâb-1 Şikeste period. This method is as a unique contribution to the field of literary synesthesia of literary synesthetes Tevfik Fikret and Servet-i Fünûn poet's. Two types of layered synesthesia are identified in Fikret's poems: co-transference and indirect chain transfer. Tevfik Fikret's conscious use of literary synesthesia in his poems to create intense emotional effects is shown in the article by utilizing Tsur's literary synesthesia approach. The original contributions of Tevfik Fikret, a Servet-i Fünûn poet, to literary synesthesia and the important functions of literary synesthesia in the poet's poetry are identified. As a result, the general attitude of Tevfik Fikret as a literary synesthete and the characteristics of the literary synesthesia he used in his poems are revealed.

Keywords: Tevfik Fikret, Servet-i Fünûn, literary synaesthesia, synesthetic metaphor, hierarchy of senses, ideasthesia

\section{Giriş}

İnsan, evreni duyuları sayesinde kavramaktadır. Dış dünyaya dair bilgileri insana ulaştıran aracılar duyu organları, duyu reseptörleri ve duyu sinirleridir. Algı "yalın duyu verilerinin düzenlenmesi ve yorumlanması olarak tanımlanabilir" (Cevizci, 2011, s. 24). İnsanın kendi bedeni ve dış dünyayla kurduğu ilişkide duyu sisteminin insanın hayatında çoğunlukla farkında olmadığı çok önemli bir yeri vardır. İnsan, bedenini kuşatan dış dünyayı algılamak için olduğu kadar kendi bedenindeki değişimleri takip etmek için de çeşitli duyulara ihtiyaç duymaktadır. Ses, tat, koku, sıcaklık, renk, şekil, basınç, zaman gibi dış uyarıcıların veya bulantı, açlık, susuzluk, cinsel heyecan, eklem hareketleri, basınç gibi vücuttaki iç değişikliklerin alıcı siniri, duyu sinirini ve duyu organını uyarmasıyla beyinde o duyuya has bölgenin uyarılarak faal hâle gelmesi sonucunda bir izlenim meydana gelmekte; bu izlenime ve bu izlenimin farkında olma durumuna genel olarak "duyu" adı verilmekte ve algı sürecinde duyulardan elde edilen ham veriler kullanılmaktadır (Budak, 2009, s. 225-226). Aristoteles'ten beri süregelen hatalı bir ön kabulle insanın beş duyusu olduğuna inanılsa da günümüzdeki bilimsel gelişmeler duyuların sayısının zannedildiğinden çok daha fazla olduğunu ortaya koymaktadır. İnsanın bugün bilinen otuz üç duyusu vardır; duyu sistemi bilinçli ve bilinçaltı olmak üzere iki türlüdür: Bilinçli duyular, bedensel duyular (temas/basınç, ısı, ağrı, özduyum) ve özel duyular (görme, tat alma, duyma, koku alma, denge); bilinçaltı duyular ise bedensel uyarımlar (kas uzunluğu ve gerilimi) ve iç organlara ait uyarımlar (kan basıncı, kan ph'sı ve oksijen düzeyi, vücut sıvılarının ozmolaritesi, kan şekeri) şeklinde çok genel olarak tasnif edilmektedir (Tanalp, t.y.). Duyuların düzenli ve benzer şekilde çalışması evrenin sağlıklı kişilerce benzer şekilde algılanmasını sağlamaktadır. Bu benzer algılama biçimi genel olarak normal addedilmektedir.

Duyuların bazı insanlarda farklı sebeplerle normal kabul edilenden farklı şekilde çalışması söz konusudur. Bu durum ilerleyen yaşta geçirilen bir hastalıktan kaynaklanabileceği gibi doğuştan da olabilmektedir. Sinestezi kavramı Yunanca birlikte anlamında "syn" kelimesi ile duyumsamak, algılamak anlamındaki "aesthesis" kelimelerinin birleşmesiyle oluşturulmaktadır (Yu, 2012, s. 1284).

\footnotetext{
Adres | Address

RumeliDE Dil ve Edebiyat Araştırmaları Dergisi $\quad$ RumeliDE Journal of Language and Literature Studies Osmanağa Mahallesi, Mürver Çiçeği Sokak, No:14/8 Osmanağa Mahallesi, Mürver Çiçeği Sokak, No:14/8 Kadıköy - ÍSTANBUL / TÜRKIYE 34714 Kadıköy - ISTANBUL / TURKEY 34714 e-posta: editor@rumelide.com e-mail: editor@rumelide.com, tel: +90 505 7958124, +90 2167730616 phone: +90 505 7958124, +90 2167730616
} 
470 / RumeliDE Journal of Language and Literature Studies 2021.25 (December) "When I was listening by my eyes": literary synaesthesia in Tevfik Fikret’s poetry and Tevfik Fikret as a literary synesthete / G. Nakıboğlu (pp. 468-504)

Psikoloji Sözlüğü’nde (Budak, 2009) verilen bilgiye göre normal addedilenin dışında genel olarak duyuların çapraz şekilde karışmasına, bir duyunun bir uyarıcı olmaksızın başka bir duyuyu tetikleyerek bu duyuların beraberce ortaya çımalarına "sinestezi" adı verilmektedir. Bir duyu organına ulaşan dış veri başka bir duyu organına ait bir duyuymuş gibi sinestezi hastalarınca algılanmakta, örneğin duyulan farklı sesler kişinin farklı renkleri görmesini sağlamaktadır; çok az sayıda kişinin tecrübe ettiği bu deneyime bazı halüsinasyon yapıcı maddeler kadar epilepsi nöbetleri de sebep olabilmektedir (Budak, 2009, s. 650-651). Sadece seslerin renkli işitilmesi değil, renklerin insana tatlarıla ulaşması ya da görüntülerin seslerle kavranması, dokunulan şeylerin alakasız bir görüntü olarak kişinin zihninde belirmesi, harf, nota ya da rakamların bazı renklerle birlikte görülüp işitilmesi de sinestezi kapsamında değerlendirilmektedir.

Güncel Türkçe Sözlük'te "sinestezi” kelimesi geçmekte ve anlamı “duyum ikiliği” olarak belirtilmektedir (Türk Dil Kurumu, 1988, s. 1988). Doğan Aksan dilbilim alanında "sinestezinin” Türkçe karşıllğı olarak "duyular arasında aktarma" gibi daha çok açıklama mahiyetinde görülebilecek bir ifade kullanmaktadır (Aksan, 2009, s. 68), Elmas ise "sinestezi" karşıllğı olarak kaynak göstermeksizin "karıştırım" terimini kullanmaktadır (Elmas, 2010, s. 35). Ancak bu terimden neyin neye karıştırıldığının anlaşılması bir yana terimin neyle ilgili olduğuna dair bir çıkarımda bulunmak dahi mümkün olmamaktadır. Klasik Türk Edebiyatı alanında Babacan "sinestezi” karşılı̆̆ı olarak "duyumlar arası geçiş" ifadesini önermektedir (Babacan, 2008, s. 221). Tek kelimenin üç kelimelik bir ifadeyle karşılanarak uzun metinler içinde kullanılması mümkün değildir ve Babacan'ın teklifi de Aksan'ınki gibi ancak bir açıklama kabul edilebilir. Yeni Türk Edebiyatı alanında "sinestezi" kavramını karşılamak üzere Aksan ve Babacan gibi uzun Türkçe ifadeler önerenler olduğu gibi, kısa ifadeleri tercih edenler de vardır. Alâattin Karaca sinestezi karşılı̆̆ı olarak oldukça kısa olan "eşduyum” terimini kullanmaktadır (Karaca, 2005, s. 222). Ancak "eşduyum" kelimesi psikoloji ve psikiyatri alanında, uzun yllardır "empati" anlamıyla yerleşmiştir (Gülseren, 2001)(Yıkmış, 2020), bu sebeple sinestezi anlamını da kelimeye yüklemek çeşitli karışıklıklara sebep olacağı için mahsurludur. Yeni Türk Edebiyatı alanında tercih "sinestezi"den yanadır (Kaplan, 2007, s. 235), (Kefeli, 2009, s. 61) (Huyugüzel, 2018, s. 599), (Akay, 2020, s. 278). Bu makalede Yeni Türk Edebiyatı alanındaki genel yönelime uygun şekilde, Güncel Türkçe Sözlük’te de yer alan "sinestezi" teriminin kullanılması tercih edilmektedir.

Bilim insanlarınca bir hastalık olarak görülen sinestezi yeteneğine sahip olan kişilere 'sinestet' adı verilmektedir. Bilim insanı Nicola Tesla, fizikçi Richard Feynman; tanınmış besteciler Liszt, RimskyKorsakov, Scriabin ve Olivier Messiaen, Rus film yapımcısı Sergei Eistenstein, Japon şair Bashõ, ünlü ressamlar Kandinsky ve Hockney, çığır açıcı şairler Rimbaud ve Baudelaire meşhur sinestetler arasında yer almaktadır (Moore, 2017, s. 11-12). Pek çok farklı alanda meşhur olmuş daha pek çok sinestetin ismini sıralamak mümkündür.

Aynı türde bir sinesteziye sahip olan kişilerin algıları farklı ve şahsidir. Sinestetler aynı sesleri farklı renklerle algılayabilmektedirler örneğin "fa majör" Rimsky-Korsakov'a yeşil, Scriabin'e mor görünmektedir, fizikçi Richard Feynmann ise fizik denklemlerindeki rakamları ve harfleri renkli algılamaktadır (Moore, 2017, s. 11-12). Sinestetlerin yaşadığı özgün kişisel deneyimin daha iyi anlaşılabilmesi için Sarah J. Harris’in Sinestezi (2019) adlı romanının sinestet baş kişisinin roman boyunca anlatılan ilginç sinestezik deneyimlerinden sadece bir bölümünü bile aktarmak sinestezinin ne kadar farklı boyutlara sahip bir durum olduğunun kavranması noktasında faydalı olacaktır. Günleri farklı renklerde algılayan roman kişisi için salı "şişe yeşili", çarşamba "diş macunu beyazı", perşembe "elma yeşili” tonlarındadır. Tanıştığı kişileri de genel olarak renklerle özdeşleştirerek algılama eğilimindedir. Avukatı Leo’yla ilk tanıştığında, onun hakkındaki algısını şöyle ifade etmektedir:

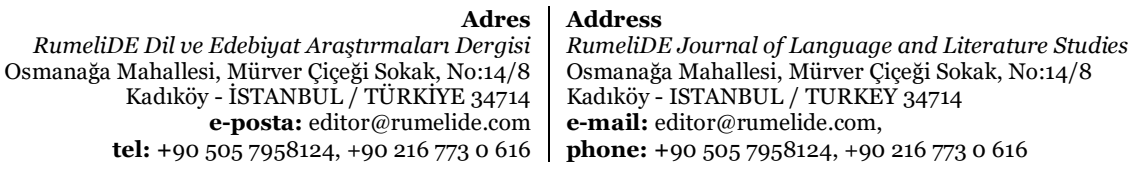



(468-504.s.)

"Renkleri zihni[n]i uyarmış ve garip, tatsız şekiller yaratmıştı[r]”, bu sebeple avukatı ilk gördüğ̈̈nde "karpuz pembemsi bir renge sahip olan, limonu düşünm[üştür]", adamın sesi ise görüntüsüyle uyumsuzdur çünkü “Leo'nun sütlü-kahverengi bir sesi var[dır] ve limona benzemiyor[dur], bu da [onun için] moral bozan bir şey[dir]" (Harris, 2019, s. 316). Sinestetlerin, yaşadıkları özel deneyimin sadece duyular arası bir çaprazlamadan ibaret kalmayıp soyut kavramlarla ilişkilerinde de duyularının farklı şekillerde devreye girmesi, bu deneyimi çoğu kişi için daha da enteresan kılmaktadır.

Nöroloji ve psikoloji profesörü Oliver Sacks, Müzikofili: Müzik ve Beyin Öyküleri (2014) adlı kitabının bir bölümünü sinestetlere ayırmaktadır. Bir hastalık olarak ilk kez 1883'te tanımlanan sinestezinin toplumda çok nadiren görüldüğünü belirten Sacks, deneyimlerinden hareketle, sinestezinin hastalar tarafından bir hastalık olarak görülmektense doğuştan kazanılmış bir armağan olarak nitelendirildiğini belirtmektedir. Kitapta bahsedilen sinestezi hastalarının ortak özellikleri müzikle farklı duyulara ait, var olmayan verileri beraberce algılamalarıdır. Haftanın günlerini, sayıları ya da harfleri renkli algılayan "harf-renk sinestezisi" hastalarının durumları basit sinestezi hastalarından oldukça farklıdır. "Müzik sinestezisi”nin görülen en yaygın sinestezi türlerinden biri olduğunu söyleyen Sacks'ın bu bağlamda tanıttığı vakalar arasında "tonal sinestezi” hastaları yani müzikle, arpejle, gamlarla bağlantılı olarak farklı tonlarda renkler görenler; müzik-tat sinestezisi hastaları (belli müzikal aralıkları ağızda bir tat olarak algılama), müzik-ışı/şekil/konum sinestezisi hastaları bulunmaktadır. Bu hastaların çoğu aynı zamanda birer müzisyendir. Müziği diğer insanlardan daha farklı şekilde işiten ve özel bir işitme duyusuna sahip olan bu kişiler müziği renkleri, tonları, tatları, şekilleriyle algılayabilmektedirler (Sacks, 2014, s. 173-184).

Richard E. Cytowic'e göre sinestezi tıp alanında üç yüz yıldır bilinmekle birlikte, 1860 ve 1930 ’larda gündeme gelmiş ancak 1980'lerdeki bilimsel çalışmalara kadar tekrar unutulmuş ya da göz ardı edilmiş bir fenomendir, nörobilim alanındaki çalışmaların artması ve gelişmesiyle fenomen tekrar hatırlanmıştır. Cytowic, klinik çalışmalarından hareketle sinestezinin istemsiz ve mutlaka bir uyarana bağlı olarak kişi tarafından deneyimlenmekte olduğu, uyaranın bilinmesinin sinestezinin türünün de bilinmesini sağladığını belirtmekte ve bu açıdan sinestetik deneyimin öngörülebilir niteliğine dikkat çekmektedir. Onun tespitlerine istinaden sinestetik algılar kalıcı ve geneldir ancak resimsel veya ayrıntılı değildir. Duyular arasındaki çaprazlama yakın duyular arasında olabileceği gibi uzak duyular arasında da gerçekleşebilmektedir. Sinestetik algı akılda kalıcıdır ve hatırlanabilirdir. Sinestezi aynı zamanda duygusaldır, kişinin sinestetik deneyimine bir kesinlik duygusu ve algılanan şeyin gerçek olduğuna dair bir inanç eşlik etmektedir (Cytowic, 1995). Sinestetlerin farklı algılayış, duyum ve duygulanım biçimlerini sanata yansıtmaları, sanat alanında bambaşka, alışılmadık, harikulade, öznel ve özel bir algısal evrenin kapılarının açılmasını sağlamaktadır. Dünyanın algılanışındaki olağanüstülük sinestet sanatçlların eserlerinde bariz bir şekilde görülebilmektedir. Sanat severler kadar sanat üzerine araştırma yapanlar için de sinestetlerin sanatla kurdukları ilişki, insan algısının farklı boyutlarının keşfedilmesi açısından olduğu kadar imgelemin genişleyen ufkunun örneklenmesi açısından da son derece cazip bir alan oluşturmaktadır.

Sanatın farklı alanlarında eser veren tanınmış pek çok sinestet vardır. Yazar Vladimir Nabokov, ressam Kandinsky, müzisyen Franz Liszt ve Wagner, şair Arthur Rimbaud, ressam Van Gogh gibi tanınmış sinestetlerin içinde yer aldığı kalabalık bir sinestet sanatçlar listesi oluşturmak mümkündür. Bu isimler sinestezi yeteneklerinin onlara sağladığı farklı algılayış biçimlerini sanatlarıyla buluşturmaktadırlar. Sanatın farklı alanlarında duyuların karışımı, karşılıklı olarak ilişkilendirilmesi, duyuların soyut kavramlarla çaprazlanması temelinde sinesteziden doğal sinestezi yeteneğine sahip olmayan sanatçlların da faydalandığı görülmektedir. Gerçek bir sinestezi yeteneğine sahip olmayan kişiler

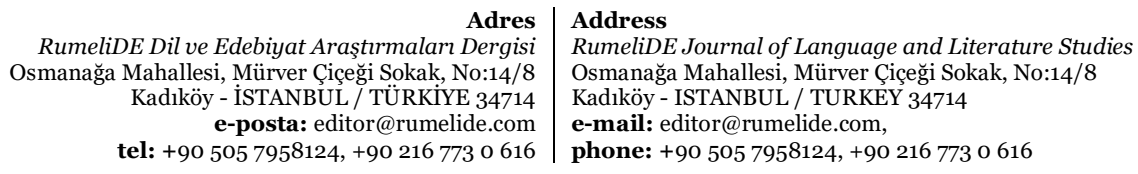


472 / RumeliDE Journal of Language and Literature Studies 2021.25 (December) "When I was listening by my eyes": literary synaesthesia in Tevfik Fikret's poetry and Tevfik Fikret as a literary synesthete / G. Nakıboğlu (pp. 468-504)

"pseudo-sinestet" (sahte sinestet) olarak nitelendirilmektedir. Sahte-sinesteziden günümüzde eğitim alanında da faydalanılmaktadır. Duyusal ikame aletlerinin uzun süre kullanımının görme özürlülerde bazı seslerin görüntüye dönüştürülmesini sağlayabildiği tespit edilmiştir (Deroy \& Spence, 2013). Edinilmiş sinesteziden farklı alanlarda öğrenme etkinlikleri bağlamında faydalanılmaya başlanmış olup etkili sonuçlar alınmaktadır (Wheeler, 2013). Edebî eserlerinde sinesteziden bir yaklaşım olarak istifade eden sanatçılara "edebî sinestet" adı verilmektedir. Sinestezi alanında ilk akademik makalelerden birini kaleme alan June E. Downey'e göre edebî eserden yola çıkarak bir sanatçının gerçek bir sinestet mi yoksa edebî bir sinestet mi olduğunu belirlemek oldukça güçtür (Downey, 1912, s. 490). Edebiyat alanında sinestezi, dil düzleminde farklı duyuların beraberce ele alınması ya da karıştırılması esasına dayanmaktadır. Edebî eserde yer alan "[B]ir imajda iki veya daha çok duyu organından gelen duyumların birbirine karışması; bir imaj içinde görme, işitme, dokunma, tatma ve koklama duyularına ait duyumların birlikte algılanması" söz konusudur ve "Bu imajlarda bir koku duyusu görme ve dokunmaya ilişkin, bir ses duyusu d[a] görmeye, tatmaya ve dokunmaya ilişkin sıfat veya benzetmelerle anlatılabil[mektedir]”, bu türlü imgelere genel olarak 'sinestetik imgeler' adı verilmektedir (Huyugüzel, 2018, s. 448). Ancak sadece bilinçli özel duyular olarak nitelendirilen tat alma, dokunma, görme, işitme, koku duyularından değil yukarıda bahsedilen farklı duyulardan (basınç, denge, zaman algısı, eklem hareketleri vb.) da sanatçıların duyuların karıştırılması ya da çaprazlanması noktasında faydalanabilmeleri mümkündür.

Her dile yerleşmiş ve sürekli kullanıldığı için sinestetik olduğu fark edilmeyen kalıplaşmış pek çok ifade vardır. Wellek ve Warren'a göre, "Tatlı söz yılanı deliğinden çıkarır” atasözündeki işitme duyusuna hitap eden "söz"ün tatma duyusuna özgü "tatlı" sıfatıyla nitelendirilmesi buna örnek verilebilir, buna benzer daha pek çok örnek sıralamak mümkündür ("güzel ses”, "soğuk renkler”, "sıcak renkler”, "şeker kız", "acılı günler", "yumuşak ses", "kalın ses”, "ince ses", "tatlı koku”, "ekşi koku”), bu tür "anlam genişlemeleri dilin içinde erimişlerdir ve artık genel olarak edebiyat ve dil konusunda duyarlı olanlar tarafından bile" metafor olarak görülmemektedir, bunlar "silik", "aşınmış" veya "ölü" metaforlardır (Wellek \& Warren, 2011, s. 226). Dilbilim alanında sinestezi üzerine yapılan çalışmalar genel olarak başta ölü sinestetik metaforlar olmak üzere sinestetik metaforların tespitine dayanmaktadır.

Sinestetik metaforlara geçmeden önce metafor kavramını tanımlamak ancak tanımlamaya geçmeden önce de adlandırma üzerinde durmak yerinde olacaktır. Metafor kavramının karşllığı olarak Türkçede farklı kaynaklarda "istiare”, "eğretileme” ve “deyim aktarması" kavramları kullanılmaktadır. Bu kavramlar üzerinde bir uzlaşı sağlanamadığı gibi $^{2}$ bu adlandırmaların farklı kaynaklarda farklı anlamlara gelecek şekilde kullanıldıkları görülmekte hatta bu kavramların metaforu tam olarak karşılamadı̆̆ tespiti de yapılmaktadır. Türkiye'de metafor kavramına üç tür yaklaşım söz konusudur. İlk grupta metafor kavramından hiç bahsetmeyenler yer almaktadır. Örneğin Cem Dilçin, Örneklerle Türk Şïr Bilgisi”nde "istiare" başlığı altında "metafor" kavramından hiç bahsetmez (Dilçin, 2009, s. 412415). İkinci grupta metaforu istiarenin ve eğretilemenin tam karşıllı̆̆ olarak benimseyen ve kullananlar yer almaktadır. Örneğin Turan Karataş, Ansiklopedik Edebiyat Terimleri Sözlüğ̈̈’nde "metafor" maddesinde "istiare" kavramına okuyucuyu yönlendirmekte, istiarenin tam karşllı̆̆ olarak ise

Örneğin Ömer Faruk Huyugüzel’in René Wellek ile Austin Warren'ın Edebiyat Teorisi adlı çalışmalarını Türkçeye çevirirken "catachresis" yani bir kelimenin ya da deyimin "kötü ve yanlıș kullanımı" karş̧llğı olarak kullandığı "deyim aktarması" kavramını (Wellek \& Warren, 2011, s. 229), Doğan Aksan Şiir Dili ve Türk Şïr Dili: Dilbilim Açısından Bakış adlı çalışmasında metafor karşılığı olarak kullanmaktadır. Aksan, "Şiir Dilinde Aktarmalar" başlığı altında yer verdiği "deyim aktarması" alt başlığı altında bu kavramın eskiden Türkçede "istiare" karşılığı olarak kullanıldığından bahsetmekte ve metafor karşılığı olarak da tanımlamaktadır (Aksan, 2013, s. 128). Hasan Akay ise Ş̈̈̈r Alametleri”nde deyim aktarmaları olarak "metaphor, trope; açık istiare, kapalı istiare, mecaz" ile "kinaye (allusion)" ve "ta'riz (insinuation)" saymaktadır (Akay, 2006, s. 95). Kısaca buraya kadar aktarılan bilgiler metafor, eğretileme, istiare ve deyim aktarması terimlerine dair dilimizde yaşanan büyük karmaşayı gözler önüne sermektedir.

Adres Address

RumeliDE Dil ve Edebiyat Araştrrmalar Dergisi $\quad$ RumeliDE Journal of Language and Literature Studies Osmanağa Mahallesi, Mürver Çiçeği Sokak, No:14/8 Osmanağa Mahallesi, Mürver Çiçeği Sokak, No:14/8 Kadıköy - İSTANBUL / TÜRKIYE 34714 Kadıköy - ISTANBUL / TURKEY 34714 e-posta: editor@rumelide.com $\quad$ e-mail: editor@rumelide.com, tel: +90 $5057958124,+90216773$ o 616 phone: +90 505 7958124, +90 2167730616 
"[B]en gözlerimle dinlerken": Tevfik Fikret’in şiirlerinde edebî sinestezi ve bir edebî sinestet olarak Tevfik Fikret / G. Nakıboğlu (468-504. s.)

"eğretileme" kavramını kullanmaktadır3 (Karataş, 2011, s. 293-296). Doğan Aksan (2013) ve Hasan Akay (2006) da benzeri bir yaklaşımı benimsemektedir. Üçüncü grupta ise metafor ile istiareyi veya eğretilemeyi birbirinden ayıranlar yer almaktadır.

Musa Demir, “Batı 'Metafor’u ve Doğu 'İstiare'sinin Mukayeseli Olarak İncelenmesi” başlıklı makalesinde istiare ile metafor arasındaki farkı şöyle ifade etmektedir: "[S]öz konusu terimler, her iki cephede de sadece birer edebi sanat, birer dil oyunu olmanın dışında ve ötesinde bir kavram alanı olarak ortaya çlkmışlardır", metafor ve istiare arasında çok büyük farklılıklar olmasa da en büyük ayrım "bu terimlere yüklenen anlamlarda[dır]", Türk-İslâm "edebiyat ve düşünce dünya[sın]da, (istiare) umumiyetle, belli kaidelere indirgenmiş bir belagat imkânı olarak" düşünülmekte, Batıda ise metafor, "özellikle felsefi planda düşünülmüş etki ve kullanım alanı genişletilerek neredeyse 'hakikatin kendisi' ya da 'bilgisi' olacak dereceye yükseltilmiş” görünmektedir (Demir, 2009, s. 88-89). Demir, ikinci ve üçüncü grupta yer alanların arasında bir yaklaşım sergilemektedir. Ömer Faruk Huyugüzel, Eleştiri Terimleri Sözlüğü'nde istiarenin metafor kavramının tam karşıllğı olmadığını belirtmekte4 ve üçüncü grupta yer almaktadır.

George Lakoff ve Mark Johnson'ın bilişim bilim alanında metafor hakkındaki çığır açıcı çalışmalarını Türkçeye çeviren Gökhan Yavuz Demir (2015), "Tercüme Hakkında” başlı̆̆ı altında konuyu ele almaktadır. Demir'e göre genel olarak sanılanın tersine metaforun Türkçedeki karşılığı "istiare" ya da "eğretileme" değildir. "Are" ve "ariyet" köklerine dayanan istiare "ödünç alma" anlamındadır ve "bir kelimenin anlamını geçici olarak başka bir kelime için kullanma"yı ifade etmektedir. Bu açıdan "istiare hem mecâz hem de benzetme özellikleri” taşımakta, benzetmenin iki ögesinden sadece birisi istiarede yer almaktadır; "eğretileme" terimi ise "istiare"nin Türkçe karşılığıdır, eğretileme "belirli bir süre sonra kaldırılacak olan, geçici, muvakkat; takma; iyi yerleşmemiş; yerini bulamamış; uyumsuz" gibi anlamlara gelmekte ve terim olarak "belli bir süre için; bir kelimenin anlamını geçici olarak başka bir kelime için kullanma; bir şeyi anlatmak için ona benzetilen başka bir şeyin adını eğreti olarak kullanma” yı ifade etmektedir. Demir'e göre bu noktada genel olarak "mecâz ifadelerin kavramlaşmadığı" temel yaklaşımından hareket edilmekte ve "mecâz" "sınırı geçmek" anlamında, terim olarak "hakikatin zıddı"nı ifade edecek şekilde kullanılmaktadır. Mecazın sadece cümle ya da mısrada kullanım esnasında ortaya çıktığı kabulü, anlamın ödünç alınmış ve geçici olduğuna dair kanaati belgelemektedir. Grekçe "meta: öte ve phrein: taşımak, yüklenmek" kelimelerinden türetilmiş "metaphora"dan gelen "metafor" "bir yerden başka bir yere götürme"yi ifade etmektedir dolayısıyla eğreti, geçici bir anlamdan değil kalıcı ve köklü bir anlamdan bahsedilmektedir, bu sebeple Demir’e göre metafor karşılığı olarak istiare ya da eğretileme terimlerinin kullanılması hatalıdır (Demir G. Y., 2015, s. 14-15). Metaforla, istiare veya eğretileme farkını bu tespitiyle en doğru şekilde ortaya koyan Demir'dir.

Karataş istiareyi şöyle tanımlamaktadır: "Bir söze, herhangi bir ilgiden dolayı sözlük anlamından başka, geçici yeni bir anlam vermektir" ancak istiare maddesinin devamında metafora hiç değinmemektedir (Karataş, 2011, s. 293-296).

Mecaz sanatlarından olan ve belâgat kitaplarında "beyân" başlı̆̆ı altında ele alınan istiarenin bir sözün başka bir sözün yerine asıl anlamının dışında, benzerlik ya da kıyas ilişkisi dâhilinde kullanılmasıyla ortaya çıtığını söyleyen Huyugüzel’e göre benzetme ilişkisi dolayısıyla "teşbih" ile "istiare" ilişkilidir ancak teşbihteki benzeyen, benzetilen, benzetme yönü ve benzetme edatından, teşbih-i beliğdeki benzeyen ve benzetilenden farklı olarak istiarelerde benzeyen ve benzetilenden sadece birinin kullanılmasıyla istiare, teşbih ve bir teşbih türü olan teşbih-i beliğden ayrılmaktadır. Batı kaynaklarındaki tanımların bizdeki belâgat kitaplarındaki istiare ve teşbih-i beliğ tanımıyla örtüștüğünü ve metaforun her ikisini beraberce kapsadığını ancak sınıflandırma noktasında Batılı kaynaklardaki metafor türlerinden sadece "implied metaphor" veya "implicit metaphor" başlı̆̆ı altında değerlendirilen "örtülü metafor"ların yani yalnızca kendisine benzetilen unsurun bulunduğu türünün istiarenin tam karşlı̆̆ı olarak değerlendirilebileceğini dile getirmektedir. Batılı kaynaklardaki metafor ile teşbih (simile) ayrımına da dikkat çeken Huyugüzel, "simile"nin metafordan teşbih edatı bulundurmasıyla ayrıldığını söylemekte; Batılı kaynaklarda benzeyen ve benzetilenin beraberce bulunması durumunda mecaz koşulunun sağlandığı kabul edilerek dil düzleminde oluşturulan yapı, metafor dairesine dahil edilirken bizde benzetilenin mecazi vasfi göz önünde bulundurulmaksızın yapının teşbih-i beliğ sayılmasıyla istiarenin metafordan ayrıldığını belirtmektedir (Huyugüzel, 2018, s. 243-245).

RumeliDE Dil ve Edebiyat Araștırmaları Dergisi Osmanağa Mahallesi, Mürver Çiçeği Sokak, No:14/8 Kadıköy - İSTANBUL / TÜRKIYE 34714 e-posta: editor@rumelide.com tel: +90 $5057958124,+902167730616$
Address

RumeliDE Journal of Language and Literature Studies

Osmanağa Mahallesi, Mürver Çiçeği Sokak, No:14/8

Kadıköy - ISTANBUL / TURKEY 34714

e-mail: editor@rumelide.com,

phone: +90 5057958124, +90 2167730616 
474 / RumeliDE Journal of Language and Literature Studies 2021.25 (December) "When I was listening by my eyes": literary synaesthesia in Tevfik Fikret's poetry and Tevfik Fikret as a literary synesthete / G. Nakıboğlu (pp. 468-504)

Makalenin asıl konusu metafor kavramını, metafor ile istiare farkını tanımlamak ya da tartışmak değildir. Metafor ile istiare ayrımının ve ilişkisinin üzerinde durulmasının sebebi bilimsel çalışmanın terime dayalı zeminini doğru inşa etme gayretinden kaynaklanmaktadır. Yukarıdaki örneklerden de görülebileceği gibi Türkçedeki terimlere dayalı bu derin karmaşa doğru bilimsel tespitlerin yapılmasına mânidir çünkü bir terim kullanıldığında o terimle tam olarak neyin kastedildiği açık ve kesin şekilde belli olmalı ve anlaşılmalıdır. Aksi takdirde tüm yapılan tespitler belirsiz bir alana göndermede bulunduğundan boşluğa düşecektir. Sinesteziye dair, makalede faydalanılacak çoğu kaynak yabancı dillerde yazılmıştır ve metaforun istiare ya da eğretileme olarak çevrilmesi iki terimin farkı göz önünde bulundurulduğunda metaforun bir kavram olarak ifade alanının dışlanmasına ve hatalı tespitlerin yapılmasına sebep olacağı gibi çalışmanın sıhhatine de gölge düşürecektir. Bu noktada terimsel olduğu kadar kavramsal bir tercih de yapılması gerekmektedir. 'İstiare'nin Türkçe karşıllı̆ı olarak kullanılabilecek 'eğretileme' açıktır ki 'metafor'u karşılamamakta, yine bir söz sanatı olarak tanıtılan 'deyim aktarması' terimi ise farklı kaynaklarda farklı anlamlara gelecek şekilde kullanıldığından incelemeyi sınırları belirsiz bir alana sürüklemektedir. Metafor kavramı çok daha geniş bir alanı kapsamaktadır. Bir edebi sanat olmaktan ziyade dil, felsefe, toplum bilim, psikolojiden temellenen anlambilim ve yorumbilim alanında (Şahan, 2020, s. 59) derin anlamlara işaret eden yapısıyla daha bütünlüklü bir inceleme için uygun görünmektedir. Makalenin teorik ve kavramsal zemininin sihhati açısından bu makalede "metafor" kavramını kullanma zorunluluğu doğmaktadır. Ayrıca günümüzde gerek edebî sinestezi alanındaki akademik çalışmalarda gerek modern metafor teorilerine dair çalışmalarda gerekse çevirilerde bir düşünme ve anlamlandırma yöntemi olarak genellikle "metafor" kavramının kullanılmasının, yukarıda belirtilen sebeplerden ötürü, tercih edildiği görülmektedir (Lakoff \& Johnson, 2015) (Cebeci, 2019) (Şahan, 2020) (Çelik, 2018). Benzeri bir yaklaşımın benimsendiği bu makalede, Güncel Türkçe Sözlüğe de giren "metafor" (Türk Dil Kurumu, 1988, s. 1546) kavramı kullanılmaktadır.

Doğan Aksan'ın, Şiir Dili ve Türk Şïr Dili kitabında “eğretileme” başlığı altında sıraladığı beş farklı türden sonuncusu sinestetik metaforları da kapsayan bir üst başlık niteliğindedir. Doğan Aksan bu türün beş alt türünü tespit etmektedir: (1) Bir duyuya ait bir sıfatın başka bir duyuyla kavranan nesneye aktarılması ("çiğ renkler", "sıcak bir ses"); (2) Duyusal algılamanın nesnesine bağlı kavramların farklı nesnelere aktarımı ("bir katre alev"); (3) Duyusal algının niteleyici sıfatının bir duyguya ya da soyut kavrama aktarımı ("altın hülya", "kırmızı pazar"); (4)Renklerin yerine renklerin akla getirdiği nesnelerin kullanımı ("renkleri nesnelerle anlatma eğilimi”: "altın şarap", "firuze kubbeler"); (5) Bir nesneyle genelde ilişkilendirilen eylemin bir başka duyuya yüklenmesi ("karanlığın sıvaşması") (Aksan, 2013, s. 143-145). Sinestetik metaforların, başlangıç mahiyetinde, temelde sıfatların, isimlerin ve eylemlerin farklı bağlamlarda farklı duyuların karşılıklı ilişkisine dayanılarak oluşturulduğu tespitini yapmak mümkündür. Yukarıda sıralanan alt türlerden dördüncüsünde bir rengin yerine geçen nesne görme duyusu dışındaki bir duyuya hitap eden bir vasfiyla diğer nesnenin nitelenmesini sağlyyorsa sinestetik metafor olarak kabul edilebilir.

Sinestetik metaforların mahiyetinin aydınlatılması yolunda özellikle 1980 sonrasında önemli çalışmalar yapan akademisyenler, geleneksel metafor yaklaşımının sinestetik metaforların yapısının aydınlatılmasında kâfi olmadığı kanaatine varmaktadırlar. Sean Day’e göre bunun en önemli sebebi sinestetik metaforların kurduğu yeni ve olağandışı çaprazlama ilişkilerdir, metaforlara retorik süsleme araçları olarak yaklaşan geleneksel metafor kuramının benzerlik ilişkisine dayanan yaklaşımının sinestetik metaforlar söz konusu olduğunda geçerli olmadığı görülmektedir çünkü çaprazlanan duyular arasında herhangi bir benzerlik söz konusu değildir ve sinestetik metaforda bir duyu diğerinin yerini almaktadır. Dolayısıyla sinestetik metaforun yapısı bu yaklaşımla aydınlatılamaz ayrıca geleneksel

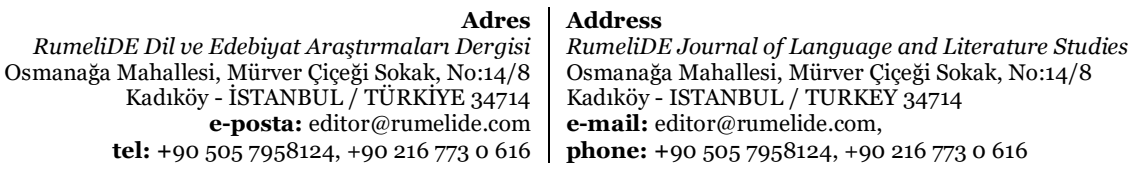



(468-504. s.)

metafor kuramının öngördüğü dilbilimsel yaklaşım semantik alanın incelemeye dahil edilmesine engel olmaktadır, bu sebeple sinestetik metaforların yapısının çözümlenmesinde kavramsal metafor kuramından faydalanılması daha uygun görünmektedir (Day, 1996). Metafora geleneksel olarak retorik bir araç şeklinde yaklaşılmasının metaforun yapısında hali hazırda var olan ve onun ortaya çımasını hazırlayan insana, insanlığa ve kültüre dair düşünsel ve deneyimsel sistemi kavrayamamaktan kaynaklandığını bir sistem dâhilinde ortaya koyan isimler, bilişim bilim ve bilişimsel dilbilim alanında çalışan Lakoff ve Johnson (2015) olur. Onlar "Metaforun gündelik hayatta sadece dilde değil, düşünce ve eylemde de yaygın olduğunu keşfe[derler]" ve "Gündelik kavram sistemi[.] -kendileriyle düşün[ülen] ve eylemde bulun[ulan] terimler- temelde doğası gereği metaforiktir”, kavramlar sadece düşünceye yön vermemekte aynı zamanda günlük faaliyetleri, dünyayı algılama biçimini, sosyal ilişkileri, eylemleri de yönlendirmekte ve gerçekliğin insan tarafından bireysel olarak keşfedilmesinde ve tanımlanmasında etkili olmaktadır. Onlara göre "Metaforun özü bir tür şeyi başka bir tür şeye göre anlamak ve tecrübe etmektir" ve metafor "tecrübe temelinden bağımsız olarak asla" hakkıyla kavranamaz. Dolayısıyla geleneksel metafor yaklaşımının zihin ile bedeni birbirinden ayırarak bedenden kopuk bir zihin tasarımıyla ortaya koyduğu metafor tanımının zıddına metafor için bedensel deneyim vazgeçilmezdir (Lakoff \& Johnson, 2015, s. 27, 30, 47). Lakoff ve Johnson'ın geliştirdikleri metafor yaklaşımı "kavramsal metafor kuramı" olarak tanınmaktadır.

Sean Day (1996), Yeshayahu Shen (1997) ve Ning Yu (2003) gibi akademisyenler sinestetik metaforlara dair araştırmalarında Lakoff ve Johnson'ın kavramsal metafor kuramından faydalanmaktadırlar. Bu akademisyenler sinestetik metaforları, kavramsal metafor kuramında metaforik haritalama olarak tanımlanan bilişsel sürecin tek yönlü ve asimetrik olup somuttan soyuta doğru hareket etmesi, metaforik haritalamanın bütünsel değil kısmî olması yani kaynak alanın yapısının hedef alanın yapısına yalnızca kısmen yansitılması, metaforik haritalamanın rastgele ve keyfî olmayıp bedene, fiziksel dünyadaki ve kültürel hayattaki günlük deneyime dayanması, metaforik haritalamanın farklı kavramsal alanlar karşısında sistematik olması temel ilkelerinden hareketle ele almaktadırlar (Yu, 2012, s. 1287). Mevzu bahis araştırmalarda Lakoff ve Johnson'ın kavramsal metafor kuramında tanımladıkları bilişsel haritalama sisteminden ve Ullmann'ın duyuları hiyerarşik olarak sinıflandırmasından ya da bu hiyerarşik duyu sınıflandırmasının geliştirilmesiyle hazırlanan sınıflandırmalardan faydalanılmaktadır. Ullmann, kavramsal metafor kuramının ortaya konulmasından çok önce duyuları sıralayarak aralarındaki ilişkileri ve sinestetik yönelimleri tespite uğraşması açısından önemli bir isimdir. Şiirde sinestetik metaforları ele aldığı çalışmasında Ullmann (1945), dokunma->tatma->koklama->işitme>görme duyularını tespit ettiği verilere istinaden hiyerarşi dahilinde sıralamakta ve sinestetik transferlerin düşük duyusal seviyeden yükseğe doğru geliştiğini ileri sürmektedir. Dokunmayı duyuların en alt seviyesi olarak tanımlayan Ullmann aktarımların çoğunun kaynağı olarak dokunma duyusunu belirlemektedir. Sinestetik aktarımların en çok yöneldiği hedef alan olarak ise işitme duyusuna işaret etmektedir. Ayrıca Ullmann sesin, sinestetik aktarımlarda görmeden daha baskın olduğu kanaatindedir (Ullmann S. d., 1945, s. 813) Dilbilim alanındaki bu tür akademik makalelerde sinestetik metaforlarda duyular arası aktarımların duyular hiyerarşisine uyup uymadığı, hangi kaynak duyu ile hangi hedef duyu arasında çaprazlama bir haritalama işlemi gerçekleştirildiği temel sorun olarak ele alınmakta, üzerinde çalışılan dile dair örneklerin edebî eserler kadar günlük dilden de seçilebildiği görülmekte ancak anlamsal ve estetik boyuta bakılmadığı gibi ölü sinestetik metaforlarla edebî sinestetik metaforlar ayrımına da gidilmemektedir. Bu makalelerde, son dönemde "corpus-based" (bütünce/derlem tabanlı) bir yaklaşım benimsenmektedir.

Alper Kumcu (2021), Türkçede dilbilimsel sinestezi üzerine yaptığı derlem tabanlı incelemesinde Ullmann’ın duyular hiyerarşisini kullanmakta, 1990-2009 arasında edebî eserlerden, günlük yazı ve

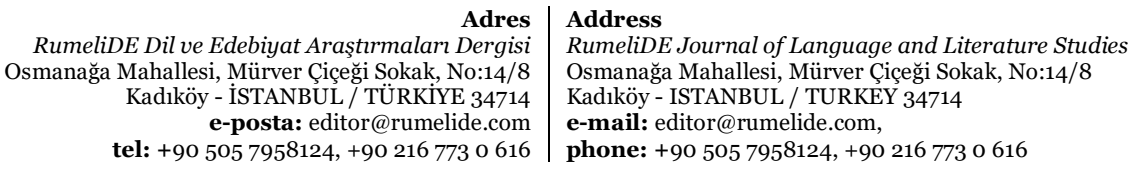


476 / RumeliDE Journal of Language and Literature Studies 2021.25 (December) "When I was listening by my eyes": literary synaesthesia in Tevfik Fikret's poetry and Tevfik Fikret as a literary synesthete / G. Nakıboğlu (pp. 468-504)

konuşma dilinden örneklerin yer aldığı 50 milyon kelimeden oluşan Türk Ulusal Derlem kaynağından faydalanmaktadır. Sıfat-isim çiftlerinin ele alındığ ${ }_{1}$ makalede fiillere yer verilmezken incelemeye isimfiiller ile zarf görevli sıfatlar dâhil edilmekte, inceleme neticesinde beş duyu arası aktarımlardan olası 20 tanesinden 19'nun Türkçede bulunduğu, en çok rastlanan duyu çaprazlamasının görme-işitme arasında olduğu, dokunmanın en sık kullanılan kaynak, işitmenin en sık kullanılan hedef duyu olduğu, tespit edilen 5693 örnekten 3885’nin $(\% 68,24)$ Ullmann'ın hiyerarşisiyle uyumlu olduğu, işitme ve görmenin çift yönlülüğü kabul edilirse oranın \%94,52'ye çıktığı yorumu yapılmaktadır (Kumcu, 2021, s. 247-248). Kumcu'nun incelemesi Türkiye'de dilbilim alanında olduğu kadar edebiyat alanındaki incelemelerde de çı̆̆ır açıı niteliği haizdir.

Sinestezi türlerinin tespiti noktasında kullanılan iki temel kavram "cross-sensory" (duyular arası) ve "cross-modal" (modaliteler arası)dır. "Sensory field" (duyu alanı): "Belli bir anda bir duyu alıcısına gelen uyarıcıların toplamı" iken "sensory areas" (duyu alanları): "Beynin, duyu ve motor sinirlerinden gelen bilgileri alan ve duyunun türüne göre özelleşmiş bölgeleri"dir (işitme, görme, dokunma vb.); "modalite” ise: "Bireyin bilgi alma, dolayısıyla öğrenme yolu", "duyu kanalı" olarak tanımlanmaktadır, "crossmodal" (modaliteler arası): "Merkezî sinir sisteminde farklı modalitelerle ilgili sinir sistemlerinin birleştirilmesi, örneğin renk algısıyla melodi algısının ilişkilendirilmesi”dir (Budak, 2009, s. 226, 494). Dilbilim alanındaki akademik incelemelerde dikkat edilirse sadece modaliteler arası çaprazlamaaktarım ilişkileri araştırılmakta ancak duyuların soyut kavramlarla ilişkilerine genelde değinilmemekte, sinestezinin sadece farklı duyular arasında çaprazlanmasına, buluşturulmasına dayanılarak farklı türleri ortaya konulmakta, incelemeler böylelikle yürütülmektedir.

Sinestezi türlerini belirleyerek ayırıp sınıflandırmaya çalışan nörobilim ve nöroloji alanındaki isimlerin sayısı özellikle yirmi birinci yüzyılla birlikte hızla artmaya başlamaktadır. Martino ve Marks, "güçlü” ve "zayıf sinestezi”yi duyular arası ve modaliteler arası olarak ayırmakta, çoğunlukla kadınlarda ve pek çok sanatçıda genetik geçişli olarak görülen güçlü sinestezinin kendisini uygun algısal deneyimde, zayıf sinestezinin ise en açık şekilde modaliteler arası metaforik dilde ve modaliteler arası eşleştirmede gösterdiğini, zayıf sinestezide seçici dikkatin önemli olduğunu belirtmekte; böylelikle dilsel ve algısal sinesteziyi farklı kefelere yerleştirmektedirler (Martino \& Marks, 2001, s. 62, 65). Sinestezi türlerini tespite uğraşan Ramachandran ve Hubbard (2001) ise sinestezinin daha önceki araştırmalarda ortaya konulan duyusal ya da kavramsal olduğuna dair çıkarımları, renk-grafem sinestezisi üzerine çalışmalarında yeniden ele almaktadırlar. Modaliteler arası ve duyular arası sinesteziyi "düşük sinestezi" olarak nitelendirmekte ve düşük formun ancak aşağı seviyedeki kortikal bölgelerde (örneğin iğsi beyin kıvrımlarında) tespit edildiğini buna mukabil yüksek sinestezinin ise yüksek kortikal bölgelerde (örneğin angular beyin kıvrımlarında) görüldüğünü ve soyut kavramlarla ilişkinin (rakam-renk ilişkisi gibi) "yüksek sinestezi" olarak diğer tür sinesteziden ayrılması gerektiğini ileri sürmektedirler. Nörobilim alanında çalışan Jürgens ve Nikolic, genel kabul görmüş sinestezinin duyuların düşük seviyede çaprazlanması fenomeni olduğu ve tetikleyicilerin doğrudan algılamaya işaret ettiği kanaati hâkim olsa da aslında ortaya konulan yeni delillerle sinestetik uyaranın algısal olmaktan ziyade semantik olduğunun keşfedilmesinden hareketle kavramsal bir tetikleyici ile algısal bir kesişimin ayrı bir isimle "ideasthesia" yani "fikirleri hissetmek" olarak tanımlanması gerektiğini ileri sürmektedirler. Onlara göre "yüksek sinestezi" semantik bileşenler içerirken, "düşük sinestezi" sadece duyusaldır (Jürgens \& Nikolic, 2012, s. 22). Nörobilim ve nöroloji alanındaki bu gelişmelerin dilbilim ve edebiyat alanındaki sinestezi incelemeleri üzerinde etkilerinin kısa sürede görülmeye başlaması kaçınılmazdır. Türkçede daha önce kullanılmayan ve bir karşıllğı bulunmayan "ideasthesia”ya bu makalede "düşünduyum" karşılığı teklif edilmekte ve yüksek sinestezi bağlamında bu terim "ideasthesia" karşılığı olarak kullanılmaktadır.

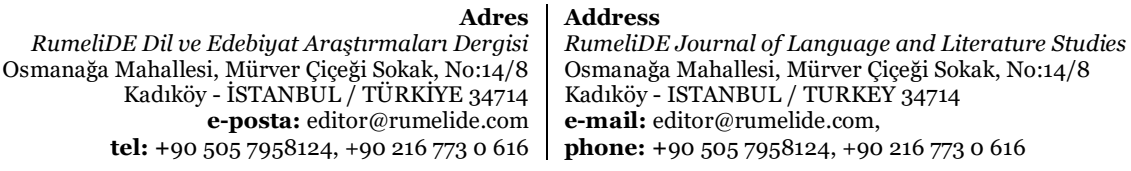


Werning, Fleischhauer ve Beşeoğlu (2006) Almanca üzerine yaptıkları, kavramsal metafor yaklaşımından hareket eden ve sinestetik metaforları dilbilimsel açıdan inceledikleri makalelerinde Martino ve Marks (2001)'ın yaklaşımından da feyz alarak öncelikle doğal dillerdeki sinestezi fenomeni ile nörolojik sinestezinin birbirinden ayrılması gerektiğini belirterek zayıf ve güçlü sinestezi ayrımına gitmektedirler; (genellikle sıfat-isim çiftlerinden oluşan) sinestetik metaforun yapısındaki hedef ve kaynak alanların her ikisinin de algısal olması durumunda "güçlü sinestetik metafor", sadece kaynak alanın algısal olması durumundaysa "zayıf sinestetik metafor" olarak tanımlanabileceğini belirterek bir sinestetik metafor tasnifi yapmaktadırlar. Bir metaforun kaynak alanının algısal olmaması durumunda sinestetik metafor sayllamayacağı kanaatine varan Werning ve arkadaşları, diğer dilbilim incelemelerinde olduğu gibi zayıf sinestetik metaforları incelemeye dâhil etmemektedirler (Werning, Fleischhauer, \& Beşeoğlu, 2006, s. 2365-2366). Zawıslawska ise zayıf ve güçlü sinestetik metaforların yakın ve uzak duyular ya da kavramlar arasında gerçekleşmesine göre "basit" ve "kompleks" olarak nitelendirilmesiyle dört ayrı sinestetik metafor türü tanımlamaktadır (Zawıslawska, 2016, s. 110-111). Sinestetik metaforların ele alındığı dilbilimsel incelemelerde sinestetik metaforların farklı türleri ortaya konulsa da nihayetinde duyular arası transferlerin duyular hiyerarşisine uyup uymadığı, hangi kaynak duyu ile hangi hedef duyu arasında çaprazlama bir haritalama işlemi gerçekleştirildiği temel sorun olarak ele alınmakta, üzerinde çalışılan dile dair örneklerin edebî eserler kadar günlük dilden de seçilebildiği görülmekte ancak anlamsal ve estetik boyuta bakılmadığı gibi ölü sinestetik metaforlarla edebî sinestetik metaforlar ayrımına da genelde gidilmemektedir.

Winter (2019)'a göre dilbilim alanındaki incelemelerde deneysel olarak sinestezi fenomeniyle sinestetik metaforların kullanımı arasında (metaforların kullanım sıklı̆̆) bir bağ olduğu gösterilemediği gibi sinestetik metaforların sinestetlerce daha fazla kullanılıp kullanılmadığı, benzer sinestetlerin benzer sinestetik metaforları kullanıp kullanmadığı (haritalamanın türü) konusunda deneysel sonuçlara, verilere ulaşılamamış, sinestetlerin sinestetik metaforları daha sık ya da halkın genelinden daha farklı şekilde kullandıkları deneysel olarak ispatlanamamıştır. Bu nedenle dilsel sinestezinin farklı modaliteler arası eşleştirmeler (cross-modal correspondences) içerdiğini dikkate almak gerekmektedir. Winter, nihayetinde sinestezi fenomeniyle sinestetik metaforların arasındaki deneysel ilişkinin gösterilememiş olmasından yola çıkarak sinestezi ile sinestetik metaforların eşitlenemeyecek iki farklı fikir olduğuna özellikle dikkat çekmektedir (Winter, 2019, s. 110). Sinestetik metaforları ya da sinestetik ifadeleri sinestezi fenomeniyle ilişkilendirerek açıklamaya çalışmanın edebî eserlere yaklaşım noktasında çeşitli hataların ortaya çıkmasına sebep olması kaçınılmazdır.

Alman Aydınlanması'nın önde gelen ismi İmmanuel Kant (1724-1804) geleneğin bilginin nesnelere uyması gerektiğine dair genel kabulünün aksine nesnelerin kişinin bilgisine ve zihinsel yapısına uyması gerektiği tezini savunmakta, "sezgilerle kavramların deneyim ve bilginin gerekli koşullarını meydana getirdiğini öne sürmektedir (Cevizci, 2011, s. 248). Kant'ın teorisini geliştirip daha düzenli ve sistemli hâle getirerek faydalanan Merlau Ponty, algının fenomenolojisi yaklaşımını ortaya koymaktadır. Ponty'nin yaklaşımı "Bir durumun anlamına açlan olarak refleks ve öncelikle bir bilgi nesnesi hedeflemeyen ve bütün varlı̆̆ımızın bir eğilimi olarak algı dünyada-varolmak” olarak nitelendirilen "nesne öncesi görüş"e uygun olup bunu "modaliteler" olarak nitelendirmekte, "[r]uhun ve vücudun birliği”ni "bilincin bir imkânı" olarak benimsemektedir (Merleau-Ponty, 2015, s. 234, 257). Lakoff ve Johnson'ın kavramsal metafor yaklaşımı da Merlau Ponty’e benzer şekilde bedenle bütünleşmiş bilinç tezine dayanmaktadır.

Clive Cazeoux (2002)'a göre Lakoff ve Johnson'ın kendisinden hiç bahsetmedikleri Ponty'nin deneyimin söz konusu olması için hem deneyimin yaşandığına dair bir öznel farkındalık duygusu hem de

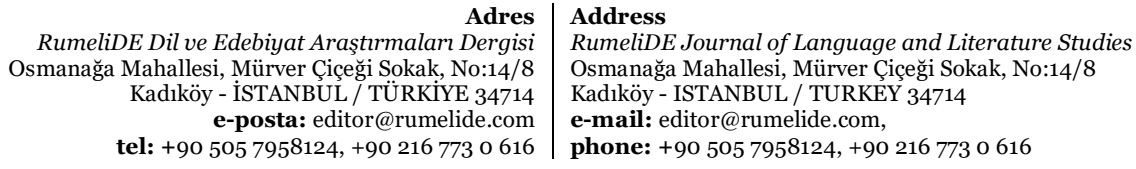


478 / RumeliDE Journal of Language and Literature Studies 2021.25 (December)

"When I was listening by my eyes": literary synaesthesia in Tevfik Fikret's poetry and Tevfik Fikret as a literary synesthete / G. Nakıboğlu (pp. 468-504)

karşılaşılan nesnenin bir etki oluşturması gerektiğine dair yaklaşımı ve bedenin ampirik bir nesne olmayıp ontolojik bir durum, bilincin ve dünyanın birbirine açıldı̆̆ beden şemasının dünyaya açılmasını ve dünyada yolunu bulmasını sağlayan şeyin duyular arası etkileşimler olduğunu belirtmesi ve temel ontolojik bir kural olarak duyuların birleşmesine dikkat çekmesi ile Ponty, Lakoff ve Johnson'dan ayrılmaktadır. Lakoff ve Johnson bir tür "ekolojik maneviyat”, a priori ve a posteriori bilgi arasında bir münasebet tesis etmeye ve bunu metaforla yapmaya çalışmaktadırlar (Cazeaux, 2002, s. 9,11, 25). Ponty'nin mutlak deneyim koşulunu Lakoff ve Johnson'ın önceki deneyimlerden istifadeyle bilişsel sistemdeki ilişkilere aktardığı görülmektedir. André Abath (2019)'e göre Merlau Ponty'nin yaklaşımında nesnelerin eylemler için tercihler sunduğu kabul edilmektedir. Karşıllk gelen bir uyaran olmaksızınn belirli bir modalite ile ilgili yarı duyusal deneyimler ortaya çıkabilmektedir, öznelerin bunları algılamak üzere bedensel bir hazırlığa girişmesi mümkün olmaktadır ve Ponty, sinestezinin böylece çözümlendiğini iddia etmektedir. Ancak Ponty’nin bahsettiği şey sadece duyusal-motor modaliteler arası etkileşimdir (Abath, 2019). Birlikte algılama yani bir nesnenin iki farklı duyu tarafından birlikte kavranması ile sinestezi kısmen örtüşse de sinestezi apayrı bir nörolojik algılama şeklidir. Zaten Ponty, her fırsatta duyuların dünyayı ayrı ayrı kavrama eğiliminde olmadığını, insanın duyular vasıtasıyla dünyayı ve nesneleri eş zamanlı olarak algıladığını belirtmektedir (Merleau-Ponty M. , 2014, s. 27-33). Bu tartışma esasen gerçek sinesteziye dair olup dil düzleminde ortaya çıkan sinestetik imgelerin ve ifadelerin Winter (2019)'ın da işaret ettiği gibi deneyimsel algıyla ilişkilendirilerek açıklanamaması sebebiyle söz konusu dilsel ve edebî sinestezi olduğunda doğrudan devre dışı kalmaktadır. Bu sebeple bu makalede Merlau Ponty'nin yaklaşımından faydalanılmamaktadır. Edebî ya da dilsel sinestetik metaforlara Ponty'nin bedenlenmiş bilinç yaklaşımını uygulamak çeşitli hatalı yorumların yapılmasına sebep olabilmektedir. Gaston Bachelard: "Poetik düşlemede duyuların tümü uyanır ve birbirine uyum sağlar. Poetik düşleme, işte duyuların da bu çoksesliliğine kulak verir; poetik bilincin kaydetmesi gereken de bu çoksesliliktir zaten" der (Bachelard, 2012, s. 7). Edebî sinesteziye, istisnai bir dışsal algının yönlendirdiği bir bilincin algısal deneyimin etkisiyle dile döktüğü sinestetik imgeler ve metaforlar şeklinde yaklaşmaktan ziyade Bachelard'ın tanımladığı şekilde poetik düsslemenin ve bilincin yönlendirdiği daha önce edinilmiş farklı duyusal algıların, zihinsel ve ruhsal dinamizmin aşkın arayışlarının izinde sinestetik imgelerde ve metaforlarda farklı şekillerde yorumlanarak ortaya konulması, birleştirilmesi, çaprazlanması, karıştırılması, birlikte zihnen deneyimlenmesi olarak edebî sinesteziyi okumak ve yorumlamak bilimsel veriler ışı̆̆ında daha mantıklı görünmektedir. Bu sebeple bu makalede Bachelard'ın çizdiği güzergâh benimsenmekte ve takip edilmektedir.

Edebî sinestetler olarak şairler ve yazarlar eserlerinde dildeki yerleşik yapılar olan ölü sinestetik metaforlardan faydalanmakta ancak bu yapıları sadece dildeki yerleşik hâliyle kullanmakla yetinmemekte, gerçek bir sinesteti taklit ederek farklı duyulara özgü kelimeleri ve duyularla soyut kavramları çaprazlayarak dil düzleminde yeni ve özgün edebî sinestezi örnekleri keşfetmeye çalışmaktadırlar. "Sinestezili birleşme ve çağrışımların bütün dillerde yaygın olduğu ve şairlerin çok haklı olarak bu gibi birleşme ve uyuşmalardan yararlandığı ve daha gelişmiş bir hâle getirdiği şüphesizdir" (Wellek \& Warren, 2011, s. 184). Özgün imgeler ve metaforlar dâhilinde ise asıl sinestetik sanat unsurları ortaya çlkmaktadır. Sinestet şairler, "ister şairin anormal psikolojik yapısının isterse edebî bir modanın sonucu olarak ortaya çıkmış olsun" oluşturdukları sinestetik imgelerle bir duyuyu farklı bir duyunun alanına taşımaktadırlar (Wellek \& Warren, 2011, s. 214). Sinestezinin dildeki bu yerleşik yapılar haricinde bilinçli şekilde edebî eserlere katılmasıyla sanatın algı evreni genişletilmekte, farklı çağrışımlara kapı aralanmaktadır. Edebî sinesteziden asıl bu örnekler dâhilinde bahsetmek gerekmektedir. Başta şiir türündeki eserler olmak üzere roman, hikâye gibi türlerde de bu tür sinestetik unsurların bazı dönemlerde sıklıkla kullanıldığı görülmektedir.

Adres Address

RumeliDE Dil ve Edebiyat Araşturmalar Dergisi $\quad$ RumeliDE Journal of Language and Literature Studies

Osmanağa Mahallesi, Mürver Çiçeği Sokak, No:14/8 $\quad$ Osmanağa Mahallesi, Mürver Çiçeği Sokak, No:14/8

Kadıköy - İSTANBUL / TÜRKIYE 34714 Kadıköy - ISTANBUL / TURKEY 34714

e-posta: editor@rumelide.com e-mail: editor@rumelide.com,

tel: +90 505 7958124, +90 2167730616 phone: +90 505 7958124, +90 2167730616 

(468-504. s.)

Reuven Tsur (2007), "Issues in Literary Synaesthesia" (Edebî Sinestezide Meseleler) adlı edebî sinesteziyi güncel yaklaşımlar doğrultusunda ele aldığı makalesinde edebî sinestezi ile özgün nörolojik sinestezinin mutlaka ayrılması gerektiğini belirtmektedir. Bunun sebebini ise özgün sinestezide duyusal modalite kombinasyonlarının tahmin edilebilir olmasına mukabil, edebî sinestezide fevkalâde esnek üretimlerin ve anlamların beklenmedik kombinasyonlarıyla karşılaşılmasıyla açıklamaktadır. Ona göre edebî sinestezide sinestetik bir metafor kullanıldığında, bu metafor sadece iki algısal bölge ile ilişkili kalmamakta "duyularüstü ama iki farklı duyu bölgesine ait olmak zorunda olmayan bir sözel yapı" özelliği arz etmektedir. Edebî sinestezi tıpkı oksimoronda olduğu gibi şiirde gerilimi arttırmak suretiyle zit ve uyumsuz nitelikleri birbirine sıkıca bağlayarak metafizik anlamlara olduğu kadar nükteli anlamlara ve modernist bağlamlara da katkıda bulunmaktadır. Tsur, edebî sinesteziden istifade edilen bir şiirde zıt ya da uyumsuz nitelikler vurgulanarak öne çlkarılıyorsa etkinin nükteli, zıt nitelikler uzlaştırılıyorsa etkinin duygusal olduğunu savunmaktadır. Edebî eserlerdeki sinestezinin yorumlanmasında Tsur dört tür açıklama imkanına işaret etmektedir: "Genetik açıklama" (şiirin edebî cazibesini hesaba katamaz), "retorik açılama" (sinestetik ifadenin unsurları sadece terimi terimine ele alınarak paralel bir benzeşim ilişkisi kurulmasıyla yetinilir), "anlamsal etkileşim açıklaması" (beklenmedik çağrışımları hesaba katar) ve "edebî sinestezi” (Ullmann’ın pankronistik yönelimlerini ve sinestetik ifadelerin gestalt 5 niteliğini ele alır). Edebî sinestezi açlklamasını tercih eden Tsur’a göre duyular arası transfer, sıradan metaforlardansa uyumsuz ve düzensiz nitelikte metaforlar üretme eğilimindedir, duygusallığı uyandırmak için Ullmann'ın hiyerarşisinde birbirine yakın olarak işaret edilen duyular arasında yumuşak bir geçiş veya farklılaşmış duyuların birbiri içinde uyumla yumuşak bir şekilde eritilmesi tercih edilmektedir (Tsur, 2007, s. 30-34).

Tsur'un makalesinde vardığı sonuçlar edebî sinestezinin incelendiği edebî metinler açısından oldukça önemlidir. Tsur (2007), yukarıya doğru transferlerin tipik olarak duygusal etkiler, aşağı doğru transferlerinse nükteli etkiler ortaya çıkardığını, kararlı karakteristik görsel şekillerin kaynaşmaya direnme ve farklı duyusal alanlardan türetilen terimlerin uyumsuzluğu arttırma, nesneden arınmış ve gestaltsız niteliklerinse birbiri içinde erimeyi kolaylaştırma eğiliminde olduğu sonucuna varmaktadır. Kaotik aşırı farklılaşmanın, aşağı doğru transferin nükteli etkisini geçersiz kılabildiği, bazı durumlarda bilişsel sistemlerdeki aşırı yüklenmenin aşağı doğru bir boşaltıma neden olabildiği tespitini yapmaktadır (Tsur, 2007, s. 49).

Estetik bir duyuş biçimi olarak sinesteziden özellikle duyuların ön planda olduğu sanat akımları bağlamında, sanatın farklı alanlarında, bir imkân olarak yararlanıldığı görülmektedir. Edebiyat bu sanat alanlarından sadece biridir. Sinestezi-edebiyat ilişkisinin geçmişi Homeros'a kadar uzanmaktadır; özellikle İngiliz ve Alman romantik şairleriyle, Fransız sembolistleri ve Proust gibi modernist romancılar da sinesteziden faydalanmışlardır (Huyugüzel, 2018, s. 449). Edebiyatta sinestezinin tarihi tahmin edilenden çok daha eskidir.

Vinge (1975)'ye göre Orta Çağ'da klasik dönem filozoflarının duyulara yaklaşımıyla uyumlu şekilde edebî eserlerde duyular simgesel olarak kullanılmaktadır. Duyular anasırı erbaa (dört temel unsur: ateş, hava, su, toprak) işaretle metinlere yerleştirilmekte, dönem eserlerinde duyularla elementlerin kombinasyonu yaklaşımı, mikro kozmos olarak insan tezine bağlanmaktadır. Bu teze istinaden dört temel element ile insan evrene uyumlanmaktadır. Vinge, bu tür alegorik simgelemeden dönem edebiyatında aşk gibi soyut

5 Almanca "biçim, şekil, düzen" anlamlarına gelen gestalt terimi Türkçeye tam olarak çevrilememektedir, "şeylerin, kendilerini oluşturan ögelerine, parçalarına indirgenerek algılanamayacağı, anlaşılamayacağı” nı ifade etmekte olup şeylerin "ancak bir bütün olarak incelendiğinde anlaşılabileceği” tezini ifade etmek için kullanılmaktadır (Budak, 2009, s. 317).

Adres $\mid$ Address

RumeliDE Dil ve Edebiyat Araştrmaları Dergisi Osmanağa Mahallesi, Mürver Çiçeği Sokak, No:14/8 Kadıköy - İSTANBUL / TÜRKIYE 34714 e-posta: editor@rumelide.com tel: +90 $5057958124,+90216773$ o 616
RumeliDE Journal of Language and Literature Studies

Osmanağa Mahallesi, Mürver Çiçeği Sokak, No:14/8

Kadıköy - ISTANBUL / TURKEY 34714

e-mail: editor@rumelide.com,

phone: +90 $5057958124,+902167730616$ 
480 / RumeliDE Journal of Language and Literature Studies 2021.25 (December)

"When I was listening by my eyes": literary synaesthesia in Tevfik Fikret's poetry and Tevfik Fikret as a literary synesthete / G. Nakıboğlu (pp. 468-504)

konuların anlatılmasında yararlanıldığına dikkat çekmektedir. Orta Çă̆'dan sonra, duyular daha az alegorik, daha çok soyut olarak anılmaya, "akıl, yargı ve insan ruhuyla ilişkili değerlerin açıklanmasında" kullanılmaya başlamaktadır. Vinge, duyuların bu türlü kullanımının insanın idrakini daha üst bir seviyede şekillendirmek için birleştirilebileceklerine dair görüşün ortaya çıkmasının edebî sinesteziye giden yolu hazırladığı kanaatindedir (Vinge, 1975, s. 50’den yorumlayarak aktaran Burrows, 2012, s. 5).

Duyuların sanat alanında bir estetik tavrı belirtmek üzere gelenekselin dişında kullanılarak 'güzel'in farklı, özgün bir arayışın nesnesi kılınması Batı'da sanat alanında Aydınlanma Çağı sonrasında başlar. Hümanizmin bireye odaklanması, Rönesans'ın bedeni yeniden keşfi yeni sanat akımlarının doğuşunu hazırlar. Romantizm, Sembolizm ve sanatsal modernizmin bedeni dayatılmış şablon beden anlayışının dışında kavrayarak bireysel bedeni önceleyip yüceltmesine bağlı olarak duyuların ve duyguların yoğunlaştırılarak kişisel deneyimin marjinalleştirilmesine yönelik yaklaşımları, sanatçıların sinesteziye tutunmalarını hazırlamakta; bu akımların insanın duyularının yönlendirdiği dışsal algılarının olduğu kadar bu algıları bütünleştirip yoğunlaştırarak yansıttıkları duygularının ve bilinçaltının sevkiyle yaşadıkları özgün ve farklı deneyimleri keşfetme noktasındaki müşterek, mütekâsif ve mükeyyef tavırları sinestetik imgelerin bu akımlara bağlı edebî sinestet sanatçlların eserlerinde kullanımını arttırmakta ve sinestezinin bir moda hâlini almasını sağlamaktadır. Başlangıçta çarpıcı bir buluş olarak görülen ve sıfatların değiştirilmesine dayanan sinestezinin edebî eserlerde kullanılmasının kanıksanıp bir moda hâline gelmesi, zamanla edebî sinestezinin "fantastik bir zorlama [ve] yozluğun itiraf," olarak görülmeye başlanmasına neden olmaktadır (Downey, 1912, s. 490). Çeşitli dönemlerde şairlerin içinde bulundukları karmaşık ruh hâlini aktarmak; doğayı, mekânı, bedeni farklı algılayışlarını yansıtacak yeni söylemler keşfetmek üzere sinesteziden günümüze kadar faydalanmaya devam ettikleri görülmektedir. Romanlardaysa sinestezi, bu olağanüstü yeteneğe sahip olan roman kişileri üzerinden gün geçtikçe şiiri geride bırakacak boyutta artan bir hızla edebiyat sahnesine taşınmakta hatta beyaz perdeye aktarılmaktadır.

Modern edebiyatta sinesteziden Alman romantikleri dolayısıyla bahsedilmeye başlanmakta ancak modern edebî sinestezi yaklaşımının kurucuları sembolist şairler Baudelaire ve Rimbaud olarak görülmektedir. Tsur'a göre gerek romantik gerek sembolist şiirde edebî sinestezi tipik bir şekilde "bulanık, rüya gibi veya tekinsiz halüsinasyon gibi ruhsal durumları veya yabancı, büyülü tecrübe veya gizemli haller gibi bilincin” başkalaşarak duyguların tanımlamadığı durumlarda kullanılmaktadır (Tsur, 2007, s. 30). Baudelaire'in "Uyuşumlar" (Correspondences) şiirinden genelde alınan "Kokular, renkler, sesler yanıtlar birbirini” (Baudelaire, 2016, s. 63) mısraı edebî sinestezinin neredeyse tanımı olarak edebî sinesteziden bahsedilen hemen her kaynakta mutlaka zikredilmektedir. Şiirde "Kendini gözetleyen simge ormanlarından" şairin bir tapınak olarak tanıttığı doğaya "[b]elli belirsiz sesler" ve "tanıdık bakışlarla" çıktığı yolculuğunda koku, renk ve ses birbirine karışmamakta, birbirine yanıtlar vermektedir. Uyanan bir duyu sirasıyla diğerlerini de uyarmakta hatta bir duyunun önceden sorduğu ve yanıtlanmasını beklediği soru, uyarıcı bir işaret olarak cevabını diğerinin uyanışıyla almaktadır. Böylece duyulardan müteşekkil bir daire tahsis edilerek simge ormanı içinde özerk bir alan konumlandırılmaktadır. "Çocuk tenleri gibi duru”, "obua gibi tatlı", "bir çim kadar yeşil" kokular ve daha niceleri "[b]edensel hazla ruhun coşkusunu şakı[rlar]", bu "nesnelerin" "sonsuz" "yaylışııdır" (Baudelaire, 2016, s. 63). Birbirini yantlayarak sonsuz bir uyum içinde döngüsel bir tarzda bütünleşen duyuların şïrde açığa çıkardığı simgesel enerji basit bir dil oyunu olmanın ötesine uzanarak Batı Edebiyatı'nın dinî temellerine ve kendine özgü simgeciliğine dayanmaktadır. Baudelaire’in bu şiirini sadece Sembolist şiirin manifestosu olarak okumak büyük bir hata olur. Özmen'e göre Platon'dan Alman romantik sanatçısı Hoffmann'a uzanan, antik dönemin ve Hıristiyan simgeciliğinin mezcedilerek şiire yansıttığı ve şiiri asıl değerli kılan, tanrısal kelâmın izlerinin yansıdığı kâinattaki sonsuz uyumun

\footnotetext{
\begin{tabular}{r|l} 
Adres & Address \\
RumeliDE Dil ve Edebiyat Araştırmaları Dergisi & RumeliDE Journal of Language and Literature Studies
\end{tabular}

Osmanağa Mahallesi, Mürver Çiçeği Sokak, No:14/8 $\quad$ Osmanağa Mahallesi, Mürver Çiçeği Sokak, No:14/8

Kadıköy - ÍSTANBUL / TÜRKIYE 34714 Kadıköy - ISTANBUL / TURKEY 34714

e-posta: editor@rumelide.com e-mail: editor@rumelide.com,

tel: +90 505 7958124, +90 2167730616 phone: +90 505 7958124, +90 2167730616
} 

(468-504. s.)

duyularla bir eş algılayış dâhilinde kavranmasına yönelik geliştirilen ifade biçimlerinin "animistik6", "simgeci" ve "alegorik" bilinçle bilinçaltının karanlık dehlizlerini buluşturan özün bu şiirde simgesel çağrışım, gönderme ve "uyuşumlarla” tebellür ettiğinin öncelikle anlaşılması gerekmektedir (Özmen, 2016, s. 224-225). Baudelaire’in sonsuz bir uyum hâline ulaşmak için duyularıla kâinata uyumlanarak doğada eriyip onunla bütünleşen insan idealine adanmış şiirinde modern edebî sinestezinin teorisi addedilebilecek yaklaşımını ortaya koyarken edebî sinestezinin kodlarına aşkınla teması doğayla bütünleşmekte arayan insan ve arayış motiflerini eklediği görülmektedir. Bu kodlar, şiirlerinde edebî sinestezi yaklaşımını benimseyen şairlerce ortak bir tavrın yansımaları olarak farklı tonlarda kullanılmakta ve bu tür şiirler simge ormanındaki duyum birliği ritüelinde bir tür yeniden doğuş arayışında buluşmaktadır.

Tsur (2007)'a göre Baudelaire'in “Uyuşumlar”inda olduğu gibi “özünün” belirsiz, mistik sezgilerde yattığı bir şiirde daha yüksek, daha fazla farklılaşmış bir duyusal alan daha düşük, daha az farklılaşmış bir duyusal alan üzerinden ele alındığında son derece yoğun etkiler ortaya çıkmaktadır. Bu etkiler sabit, karakteristik görsel şekillerin dahil olmadığı, nesnesiz ve gestaltsız nitelikler bağlamında ortaya çıtıklarında tipik olarak bazı nükteli etkiler elde edilmektedir. Bu nükteli etki ancak "kaotik aşırı farklılaşma" olarak nitelendirilebilecek istisnai olarak akışkan bir bağlamda geçersiz kılınabilmektedir. Tıpkı resim ve müzikte sistemin kapasitesini aşan tüm bilgilerin geri plana atılmasında olduğu gibi algısal aşırı yük bilişsel sistemde ezici bir üstünlük kazanabilmektedir. Kaos ve aşırı farklılaşmayı yaratan bağlamlarda, sembolist şiir duyular hiyerarşisinde "aşağı doğru" duyusal aktarımlara sik sık başvurmaktadır (Tsur, 2007, s. 43-44).

Modern edebî sinestezi söz konusu olduğunda bir diğer zikredilmesi gereken şiir, Rimbaud'un renk-harf sinestezisini edebî olarak geliştirip simgesel sinestezi ormanına dâhil ettiği, "A kara, E ak, U yeşil, O mavi: sesliler/ Diyeceğim bir gün gizli doğumlarınızı da" mısralarıyla başlayan "Sesliler" (Voyelles) şiiridir (Rimbaud, Sesliler, 1968, s. 28). "Sözün Simyası"nda bu keşfini şair şöyle açıklamaktadır:

\begin{abstract}
"Nice zamandır tüm olası görünümleri edinmekle övünüyor ve gülünç buluyordum çağdaş resmin ve çăgdaş şiirin ünlülerini. [...] aptalca nakaratları ve basit halleriyle seviyordum eski türden yazını. [...]Rengini buldum sesli harflerin: A kara, Ö ak, I kırmızı, O mavi, Ü yeşil. Her sessiz harfin biçimini ve devinimini yeni bir düzene koydum ve harfler arasındaki içgüdüsel ses uyumlarıyla bir gün bütün duyularca benimsenebilecek şiirsel bir söz bulmakla övündüm. [...] İşe incelemeyle başladım. Sessizliği, geceleri inceliyor, sözle anlatılamayan şeyleri saptıyordum. Saptıyordum hayal alemlerini. [...] Söz simyamda şiirsel eskiliğin haylice yeri vardı. Yalın sanrıya alıştım, düpedüz [...] canavarlar, gizemler görüyordum; bir güldürü oyunu adı dehşetler saçıyordu önümde” (Rimbaud, 2001, s. 26).
\end{abstract}

Rimbaud, sesli harfleri renklerle özdeşleştirirken basit bir söz oyununun peşinde değildir. Öznel bir algısal evrende, harflerle simgesel, özerk ve özdeş dünyalar kurarak o dünyalardaki özgün deneyimi özel dairesel bir simgesellikte (Omega) bütünleştirmenin özenci içindedir. Baudelaire ve Rimbaud bu iki şiirle, adeta edebî sinestezinin simgesel ve döngüsel evrenini teorik olarak inşa ederken duyulardan duyulara, duyulardan kavramlara ve duygulara ağlar atarak bilincin temel metaforik haritalama sistemini değiştirmekte ve onların ürettiği bu sanatsal özgün sinestetik bilinç, pek çok sanatçıyı insanın sınırlarını duyulardan hareketle zorlayarak aşmaya teşvik etmektedir.

Türk Edebiyatı'nda sinesteziden bahsetmek için Batı etkisinde gelişen Türk Edebiyatı'na gitmeden ve Batı etkisini araştırmadan önce geleneksel şiire bakmak daha doğru tespitlerin yapılabilmesi için elzemdir. Klasik Türk şiiri, sanılanın aksine edebî sinesteziye hiç de yabancı değildir. Mum (2006)'un

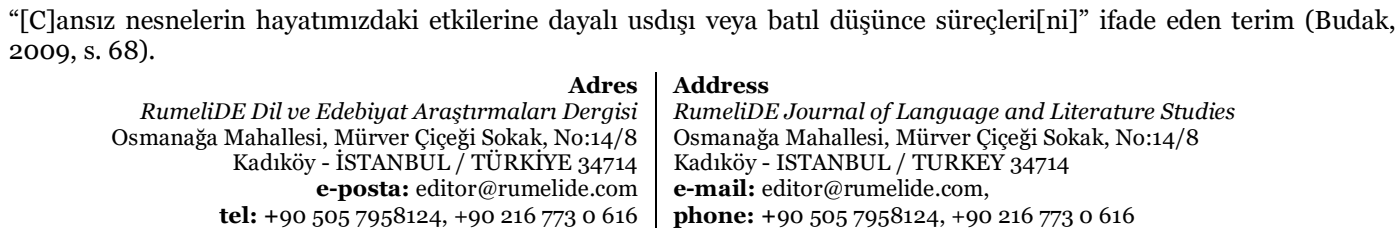


482 / RumeliDE Journal of Language and Literature Studies 2021.25 (December)

"When I was listening by my eyes": literary synaesthesia in Tevfik Fikret's poetry and Tevfik Fikret as a literary synesthete / G. Nakıboğlu (pp. 468-504)

verdiği bilgiye göre 16. yüzyllda Hint-İran bölgesinde ortaya çıkı 17. ve 18. yüzyılda Türk şiirini derinden etkileyen Sebk-i Hindî akımı ile sinestezi şiire bir edebî sanat olarak taşınmaktadır. Mum, Sebk-i Hindî’nin özellikle Bîdil-i Dihlevîce temsil edilip hayal unsurunu öne çlkaran kolunda edebî sinesteziye ayrı bir önem verildiğini belirtmektedir. İranlı Dr. Kedkenî tarafından sinesteziden esinlenilerek "hiss-âmîẑ̂" olarak nitelendirildiği belirtilen sinestezinin Klasik Türk şiirinde de yaygın bir şekilde kullanıldığına dikkat çekilmektedir. Mum’a göre dönem şairlerinin şiirlerinde Fehîm’in "nevâ-yı germ”, Nedîm'in "şu'le-i âvâz", Nâilî-i Kadîm’in "şemîm-i nâz", Nâbî̀nin "sühan-ı telh" ve "türşî̀i rû", Antakyalı Münîf in "sît-i rev-â-rev-i nigeh" gibi daha pek çok örnek bulmak mümkündür (Mum, 2006, s. 134, 137). Ancak o dönemde bu edebî sanatın özel bir isimle nitelendirilmediği anlaşılmaktadır. Babacan'a göre Türk şiirinde sinesteziyle farklı dönemlerde karşlaşılmakta ancak sinesteziye "Sebk-i Hindî döneminde sıklıkla başvurularak seçkin örnekleri ortaya kon[ulmaktadır]" (Babacan, 2008, s. 221). Halk Edebiyatı'nda da dilde yerleşik olarak kullanılan pek çok sinestetik ifadenin yanında özgün sinestetik metaforların ve ifadelerin yer aldığını tahmin etmek güç değildir. Yeni Türk Edebiyatı eserlerinin incelenmesinde edebî sinestezi ele alınırken maatteessüf geleneksel şiirdeki sinesteziden hiç bahsedilmediği görülmekte, edebî sinestezinin Servet-i Fünûn Dönemi’nde tamamıyla Batı'dan alındığına dair yerleşik bir söylemle karşılaşılmaktadır.

Batı Edebiyatı'nın cezbesine tutulan on dokuzuncu yüzyıl Türk edebiyatçllarından özellikle "Servet-i Fünûn" ya da diğer adıyla "Edebiyât-ı Cedîde" sanatçıları sinesteziye ayrı bir önem vermekte ve eserlerinde sinestetik metaforlar kullanmaktadırlar. Konuya ilk dikkat çeken isim Mehmet Kaplan olur. Mehmet Kaplan (2007), Tevfik Fikret: Devir-Şahsiyet-Eser'de Tevfik Fikret'in sıfatları kullanım noktasında sinesteziden faydalandığını belirtmekte, "Maddî sıfatları maneviyata, manevî sıfatları maddiyata nakil usulü[nün], romantiklerin icadı" olduğunu ifade etmektedir. Kaplan romantiklere ve bilhassa Hugo'ya, "bu yolda fevkalâde misaller verme[leri]" dolayısıyla işaret etmekte ayrıca aynı yöntemden faydalanan meşhur sembolistlerden Baudelaire ve Rimbaud'un etkisiyle sinestezinin kısa sürede tüm şairlerce kabullenilip kullanılmaya başlandığını ve bu "tesiri[n] bizim edebiyatımıza kadar gel[diğini]” özellikle vurgulamaktadır (Kaplan, 2007, s. 235). Mehmet Kaplan'ın görüşünü devam ettiren Hasan Akay (2020): "Türk şiirinde o zamana kadar görülmemiş orijinal sıfat ve isim tamlamaları meydana getir[en]" Servet-i Fünûncuların "Baudelaire ve Rimbaud'dan devşirdikleri bu tekniğin, 'ifâde correspondance'ı tarzına da yer ver[diklerini]” belirtmekte, "Muhtevadaki fikirlerin akışına yardım eden bu tarz correspondance'a, son iki mısradaki kafiyeli beyt ile şiirin kesin bir açıklğa kavuşmasına yardımcı olan Shakespearyen sonnet'de rastlandı̆̆ $\breve{g}_{1}[\mathrm{n}$ ] " eklemektedir. Sinesteziyi bir teknik olarak gören Akay’a göre Servet-i Fünûncuların kullandığı sinestezinin "metafizik bir kaynağı veya açılımı söz konusu değildir" (Akay, 2020, s. 279-280). Rimbaud, Baudelaire, Novalis gibi sembolist ve romantik şairlerin şiirlerinde sinestezi üstüne incelemeler yapan isimlere göre ise durum oldukça farklıdır.

Reuven Tsur, çok farklı bilinç durumlarıyla ilişkili olan edebî sinestezinin sıklıkla vecd şiirleriyle alakalı olduğunu söylemektedir (Tsur, 2007, s. 42). Özellikle Romantizm akımına bağlı eserlerde mebhûs vecd hâlinin mistik boyutu öne çıkmakta, Sembolizm akımı çerçevesinde verilen eserlerdeyse mistik yön simgesel olanda eriyerek onunla kaynaşmakta ve sembolist şiirler bu açıdan romantik şiirlerden ayrılmaktadır. Fulya Çelik'e göre romantik şairler için sinestezi "görünen ve bilinenin ötesinde bir yerlerde saklı, yüce ya da mistik olanı ifade etmenin" bir yoludur (Çelik, 2018, s. 43). Yine Medine Sivri ve Fulya Çelik Özkan Rimbaud'un "Sesliler" şiiri hakkındaki makalelerinde, şiirin sonunda "kutsal Sûr"dan, "meleklerden" ve "Omega"dan bahsedilen kısımda sinestezinin "olağanüstü bir duruma, bir anlamda epifaniye işaret et[tiğini]" belirtmektedirler (Sivri \& Çelik Özkan, 2020, s. 113). Edebî sinestezinin sadece bir teknik olarak görülmesi Tsur'un (2007) "retorik açıklama" olarak tanımladığı açılama türünde kalınarak farklı anlamsal göndermelerin göz ardı edilmesine sebep olmakta ve edebî

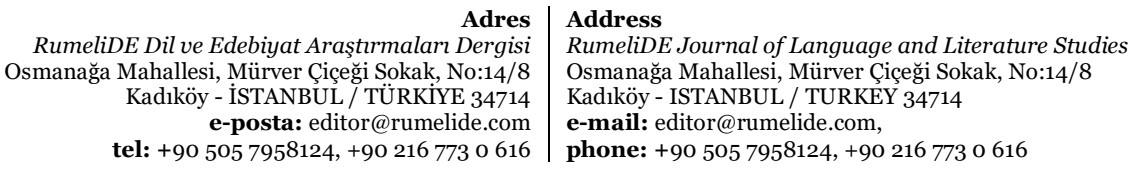


sinestezinin şiirde ortaya çıkışını hazırlayan ruhî ve bilişsel sürecin anlamlandırılmasını engellemektedir. Burrows (2012)'a göre romantik sinestezinin başlıca niteliklerinden biri, doğanın yüce vasıflarının ifadelendirilmesi ve "yükselme" (sublime) fikridir, romantik şairler zorlayıcı sanayi devrimine kısmen de olsa yükselme/yücelme kavramıyla karşı koymaya çalışmaktadırlar. Sembolist şairlerse Burrows’a göre sinesteziyi edebî manifestolarının açlk bir bileşeni kılarak dünyada var olduğunu sezinledikleri bağların ortaya konulması için duyuların birliği tezine tutunmaktadırlar. Onlar duyuların birliğinden hareketle gerçekliğin birliğini simgesel olarak ifade etme gayretindedirler. İşte tam da bu sebeple onlar için kokuların, renklerin ve seslerin uyuşumu yarı dinî bir öneme sahiptir (Burrows, 2012, s. 36, 48-49). Edebî sinesteziyi bir teknik olarak görmek tüm bu etkileşim ve anlam dairesini görmezden gelmeyi ifade etmektedir.

Batı etkisinde gelişmekte olan Türk Edebiyatı'nda şiirde sinestezi söz konusu olduğunda akla gelen ilk isim, Kaplan'ın da tespiti doğrultusunda hep Tevfik Fikret olmaktadır. Klasik tarzda şiirler yazarak sanat hayatına başlayan ve genelde Parnasizm akımının bir temsilcisi olarak tanıtılan Tevfik Fikret'in Sembolist şiirin meftun olduğu edebî sinesteziyi kullanması kafa karıştırıcı görünmektedir. Oysa Hilmi Uçan (2018)'ın yerinde tespitiyle Tevfik Fikret'i sadece Parnasizm akımı ile ilişkilendirmek büyük bir hatadır. Uçan'a göre Tevfik Fikret, Parnasizm ile olduğu kadar Romantizm ve Sembolizm akımlarıyla da ilişkilidir. Zaten Fikret'in esinlendiği şairler listesi oldukça kabarıktır ve farklı akımlardan pek çok ismi (Örneğin F. Coppée, C. Baudelaire, A. de Musset, E. Allan Poe, Leconte de Lisle, S. Prudhomme, V. Hugo) barındırmaktadır (Uçan, 2018, s. 71-72). Çeşitli kitap ve makalelerde Tevfik Fikret'in şiirlerinde sinesteziden, genelde kısaca bahsedilmekte Kaplan'ın işaret ettiği çerçevenin dışına çıkmayan kısa yorumlarla iktifa edilmektedir. Tevfik Fikret'in şiirlerinde sinestezi herhangi bir müstakil çalışma dâhilinde ele alınmamış, incelenmemiş ve değerlendirilmemiş bir konudur.

Yeni Türk Edebiyatı alanında hazırlanan 'Yeni Türk Edebiyatı’nda sinestezi' başlı̆̆ını taşıyan ya da herhangi bir Türk şairinin, romancısının ya da öykücüsünün eserinde sinesteziyi ele alan bir çalışma, inceleme söz konusu değildir. Sadece İlhan Berk’in şiirlerinde sinesteziden bahseden Güzel Sanatlar Anabilim Dalı’nda hazırlanmış "Resim ve Şiir İlişkisi Işığında İlhan Berk Sanatı" adlı bir yüksek lisans tezi bulunmaktadır (Morsunbul, 2006). Fulya Çelik tarafından hazırlanan, edebî sinestezi konusunda Türkçe olarak yazılmış, sinestezi konusunu derinlemesine ele alan doktora tezi oldukça kapsamlıdır. Bu tezde Alman Romantizm ve Fransız Sembolizm akımları bağlamında seçilmişs şiirler, yöntem olarak Ponty'nin beden teorisi, fenomenoloji (Cenevre Ekolü), Tsur'un bilişsel biçembilim yaklaşımı ve John Searle’ün söz edimi teorisi kullanılarak incelenmektedir (Çelik, 2018). Aynı yazarın tezden türetilmiş çeşitli makaleleri de bulunmaktadır. Alper Kumcu'nun hazırladığı derlem tabanlı, Türkçede genel olarak dilsel sinestezi konusunu ele alan makale ise 2021'de yayımlanmıştır. Konunun Türkiye'de dil ve edebiyat temelli akademik inceleme ve araştırmalar için oldukça yeni olduğu açıktır. Yeni Türk Edebiyatı alanında güncel yaklaşımlardan istifadeyle Türk şiirinde edebî sinestezi konusunun ele alındığı ilk müstakil makale budur. Alanda bir ilk olması dolayısıyla edebî sinestezi ile ilk özdeşleştirilen isim olan Tevfik Fikret’in şiirleri makalede ele alınmaktadır.

\section{Amaç ve yöntem}

$\mathrm{Bu}$ makalenin temel amacı daha önce müstakil bir inceleme dahilinde ele alınmayan Tevfik Fikret'in şiirlerinde edebî sinesteziyi ele alarak farklı boyutlarıyla tartışmak ve şairin üslûbunun önemli bir unsurunu teşkil eden edebî sinestezinin, şairin şiirlerindeki geniş ve derin etkisini belirlemek yanında Tevfik Fikret’in edebî sinestet kimliğini ortaya koymak ve Yeni Türk Edebiyatı alanında daha sonra yapılacak çalışmalara bir örnek teşkil etmek, yöntem sunmaktır. Makalenin alanında bir ilk olması

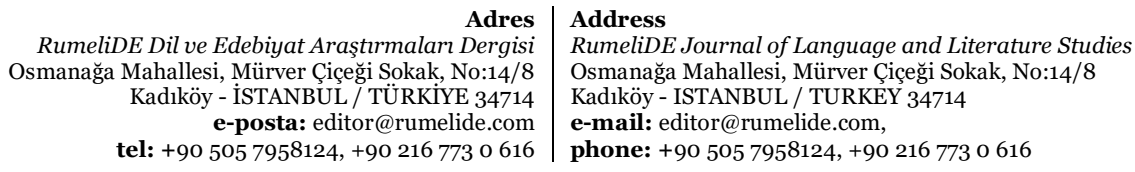


484 / RumeliDE Journal of Language and Literature Studies 2021.25 (December)

"When I was listening by my eyes": literary synaesthesia in Tevfik Fikret's poetry and Tevfik Fikret as a literary synesthete / G. Nakıboğlu (pp. 468-504)

sebebiyle çalışma yöntemini belirlerken öncelikle sinestetik metaforların şiirlerdeki türlerinin belirlenmesi yoluna gidilmektedir. Sinestetik metaforların üç türü temel olarak ele alınmaktadır. Bu türlerin belirlenmesinde iki farklı yaklaşımdan istifade edilmektedir. Bunlardan ilki bir üst ayrım olarak benimsenmektedir. Jürgens ve Nikolic'in semantik bileşenler içeren "yüksek sinestezi" ile sadece duyusal bileşenler içeren "düşük sinestezi" (Jürgens \& Nikolic, 2012) ayrımı, temel ayrım olarak belirlemektedir. Jürgens ve Nikolic’in tanımladıkları, Türkçede daha önce kullanılmayan ve bir karşılığı bulunmayan "ideasthesia"ya bu makalede "düşün-duyum" karşılı̆̆ teklif edilmekte ve yüksek sinestezi bağlamında bu terim "ideasthesia" karşılı̆̆ı olarak makalede kullanılmaktadır. Bu üst ayrım yapıldıktan sonra "düşük sinestezi”, Werning, Fleischhauer ve Beşeoğlu'nun sinestetik metaforun hedef ve kaynak alanlarının her ikisinin de algısal olması durumunda "güçlü sinestetik metafor", sadece kaynak alanın algisal olması durumunda "zayıf sinestetik metafor" olarak tanımlamalarından (Werning, Fleischhauer, \& Beşeoğlu, 2006, s. 2365-2366) hareketle, kendi içinde yeniden ikiye ayrılarak iki alt başlık dahilinde ele alınmaktadır.

Makalede inceleme safhasında öncelikle İsmail Parlatır ve Nurullah Çetin'in hazırladıkları Tevfik Fikret: Bütün Şïrleri (Fikret, 2020) kitabındaki şiirler tek tek incelenerek bahsi geçen üç farklı türdeki sinestetik metaforlar tespit edilmektedir. Tevfik Fikret'in şiirlerinde edebî sinestezinin gelişim seyrini takip etmek ve şairin üslubunun bir parçası hâline gelen edebî sinesteziyi hangi etkiler dâhilinde şiirlerinde kullandığını belirlemek üzere, Tevfik Fikret’in şiirine genel bir yaklaşımla, şiirinin özellikleri ve farklı dönemlerinin kısaca tanıtılmasının ardından, ilk şiirlerini verdiği dönem, Rübâb-ı Şikeste dönemiyle Rübâb-ı Şikeste sonrası dönem olmak üzere üç farklı dönemde şiirlerindeki edebî sinestezi örnekleri ayrı ayrı ele alınarak değerlendirilmekte, Batı şiiri yanında Klasik Türk şiiri ve Sebk-i Hindî etkisi, Türk Halk şiiri etkisine de değinilmektedir. Her üç dönemde de üç farklı türde sinestetik metaforlar ayrı ayrı alt başlıklar içerisinde ele alınırken edebî sinestezinin hangi duyular arasında ya da hangi kaynak ve hedef duyulara yöneldiği tespit edilerek Ullmann (1945)'ın duyular hiyerarşisi doğrultusunda bu tercihin genel hususiyetleri ve onun şiiriyle örtüşen yönleri açıklanmaktadır. Tevfik Fikret'in özellikle Rübâb-ı Şikeste döneminde bu makalede ilk defa tanımlanan "katmerli sinestezi" yöntemini kullanmayı tercih ettiği tespit edilmektedir. Bu birer edebî sinestet olarak Tevfik Fikret'in ve Servet-i Fünûn şairlerinin edebî sinestezi alanına özgün bir katkısı olarak kaydedilmektedir. Katmerli sinestezinin Fikret'in şiirlerinde iki türü belirlenmektedir. Bunlardan ilki makalede "birlikte aktarım" ikincisi ise "dolaylı zincirleme aktarım" olarak ilk defa tanımlanmakta ve özellikleri hakkında bilgiler paylaşılmaktadır. Bu makalede ilk kez tanımlanan katmerli sinestetik metaforların ve türlerinin Tsur'un tanımladığı "kaotik aşırı farklılaşma" temininde kullanılan yöntemlerden biri olarak değerlendirilmesi ve bu başlık altına eklenmesi teklif edilmektedir.

Her üç dönemde de sinestetik metaforların türlerinin tasnifi ardından şairin sinestetik metaforları o dönemde kullanım şekli belirlenmekte ve kullandı̆̆ sinestetik metaforların şiirin geneline olan katkıları ele alınarak tartışılmaktadır. Tsur (2007)'un yukarıda belirtilen edebî sinestezi yaklaşımı doğrultusunda sinestetik metaforlar edebî açıdan ele alınarak inceleme derinleştirilmekte, Tevfik Fikret’in şiirlerindeki yoğun duygusal etkinin sebeplerinden biri olarak "aşırı kaotik farklılaşma" ve "kaotik sinestetik enerji yığılımı" konuları seçilen örnek şiirler ve şiir parçaları çerçevesinde ele alınarak bütüne dair çıkarımlar dâhilinde yorumlanmaktadır. Nihayetinde Tevfik Fikret'in bir edebî sinestet olarak tavrı belirlenerek ortaya konulmaktadır. Alanda yapılacak daha sonraki çalışmalara bu makalenin gerek tasnif gerek inceleme yöntemi açısından gerekse Tevfik Fikret'in şiirlerine olduğu kadar Cenap Şehabettin başta olmak üzere ortak şiir idealini paylaştı̆̆ı Servet-i Fünûn şairleri yanında diğer edebî sinestet şairlerin şiirlerine yeni ve özgün yaklaşımların yolunu açması noktasında katkı sunması beklenmektedir.

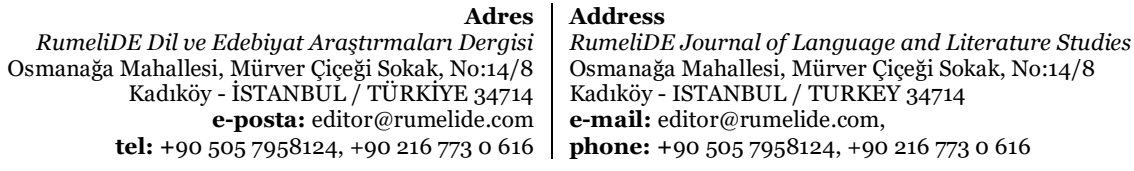




\section{Tevfik Fikret'in şiirlerine genel bir bakış}

Tevfik Fikret 1867 İstanbul doğumludur. Asıl adı Mehmet Tevfik’tir. Farsça hocasının tesiriyle Klasik Türk şiiri nev’inde gazeller yazarak şiire başladığı Galatasaray Sultanîsi’nde okuduğu yıllarda Recaizade Mahmut Ekrem, Muallim Naci, Abdülhak Hamid Tarhan gibi dönemin sevilen şairlerinin şiirlerini takip etmekte ve onlara nazireler yazmaktadır (Parlatır, 2012, s. 11). Klasik şiirin kaidelerini öğrenen, klasik ruhun şiire aksinin temellerini keşfeden Tevfik Fikret’in ilk dönem şiirleri eski ile yeni arasındaki bir gidiş gelişteki kararsızlı̆̆ı sergilemektedir. Bu dönemde yazdığı bazı şiirlerini daha sonra ünlenmesini sağlayacak Rübâb-ı Şikeste’ye de alan Tevfik Fikret'in şiirlerindeki köklü değişim Servet-i Fünûn Dergisi'nin yönetimine geçmesini takip eden dönemde dergi etrafında ortak görüş, kanaat ve hayalde buluşan şair ve yazarların bir edebî topluluk teşekkül ettirmeleriyle kendisini iyice göstermeye başlamaktadır. 1896 ile 1901 yılları arasında faaliyet gösterecek Servet-i Fünûn topluluğu başta Dekadanlık tartışması olmak üzere pek çok tartışmaya girecek, pek çok eleştiriye muhatap olacak ve çok da ilgi görecektir. Bu eleştirilerin genelde, şairlerin Batı şiirine beklenmedik, aşırı derecede teveccüh ve temayüllerinden kaynaklandığı görülmektedir. Tevfik Fikret'in şiirlerini topladığı ve on dokuzuncu yüzyılın son şiir kitaplarından biri olarak hazırlanıp yirminci yüzyılın ilk şiir kitaplarından biri olarak yayımlanma şansı yakalayan7 eseri, Rübâb-ı Şikeste'dir. Kitabın adı, klasik şiirin kelimeleriyle oluşturulmuş olsa da dilin zaptının fikrî meyle engel teşkil etmediğini belgelemektedir. Nitekim dil de değişen bilincin yakın zamanda aksettiği bir ayna olmaktan kurtulamayacak dönem şairlerinin elinde kırılıp yeniden birleştirilerek kolaj bir lügat mahiyetinde düzenlenecektir. Kitabın adından ${ }^{8}$ başlayarak fark edilen yeniliğin söyleyişte olduğu kadar duyuş, seziş, düşünüş, bakış ve algılayışta da köklü bir kayışın etkilerini aşikâr ettiği alenidir bu değişim ideolojik bir kayışı da (bazen rücu edilen bir zelli) peşi sıra getirmektedir. Tevfik Fikret Rübâb-ı Şikeste'den sonra Halûk'un Defterinden, Hemşirem İçin, SisRücû, Bir Lâhza-i Ta'ahhur, Millet Şarkısı, Âveng-i Tesâvir, Âveng-i Şühûr, Halûk'un Defteri, Hayata Karşı Beşer, Hitâbeler ve Şermin'i yayımlatır; "Târîh-i Kadîm", "Doksan Beşe Doğru", "Rübâbın Cevabı", "Hân-ı Yağma”, "Târîh-i Kadîm'e Zeyl -Bir Cevâb-", "Sancak-ı Şerîf Huzurunda" ise son şiirleri arasındadır ayrıca Tevfik Fikret’in az sayıda da olsa çeviri şiirleri de bulunmaktadır (Fikret, 2020). Fikret'in şiir külliyatı oldukça hacimlidir ve onun şiirlerinde pek çok yönelimi, pek çok tesirin izlerini beraberce tespit etmek mümkündür. Dönem koşulları gereği şairlerin külliyatlarını yekpare bir şiir anlayışının numunesi olarak görme çabası beyhudedir. Bu dönem şairlerinin külliyatlarını sürekli değişen, çalkantılı bir denizde daimî öldürücü darbeler indiren dalgalar arasında tufandan kurtulmak idealiyle yol alan gemiler olarak değerlendirmek daha doğrudur. Bu gemilerin kaptanları her nev’i fikri, duyuşu ve sezişi ihtiyaç hâlinde kullanmak üzere gemilerine yedekleme hasletini düstur olarak benimsemişlerdir. Araf ta ruhları taşıyan bu büyük gemiler, bir taraftan yıkılıp bir taraftan yeniden inşa edilen Theseus'un gemilerine benzerler ve yol alırken her daim yıkılıp yeniden inşa edilirler.

Değişimin temelini değişenin kendinde aramaya başlamayıp harici ve müteselsil etkilerde aramanın mahsurlarını, müsebbibin keşfini tespitteki kifayetsizliğin onulmaz neticelerini göz ardı etmek her alanda mükerrer hatalar zincirini başlatır. Bu hatalar zincirinin ilke edinilerek gerçeğin örtülmeye çalışılması ise bir avuntunun ötesine geçmeyip daha büyük ve geri dönülmez neticeleri olan hataların yapılmasının önünü açar. Bu gerçeğin farkında olan Tanpınar, 19 uncu Asır Türk Edebiyat Tarihi (1997)'nde köklü ve yerinde tespitler yapabilmek için, Osmanlı'nın son dönemine bakmadan, doğrudan

Tevfik Fikret, "1896-190o yılları arasında yazdığı ve Servet-i Fünûn dergisinde neşrettiği şiirlerinin büyük bir kısmını 1899 yılının sonunda Rübab-ı Şikeste adı altında topladı. Şubat 1900’de satışa çıkarılan kitap kısa bir zamanda tükendi, bir ay sonra tekrar basıldı. 1910 yılında şair, 1900-1909 ylları arasında yazdığı manzumeleri de ilâve ederek, Rübab-ı Şikeste'nin üçüncü baskısını yaptırdı" (Kaplan, 2007, s. 97).

8 Kaplan'ın Rübâb-ı Şikeste adının Prudhomme’un “Le Vase brisé” (Kırık Vazo)sinden gelmekte olduğu görüşüne katılmayan Özmen'e göre şiir kitabının adı Musset'nin “luth” undan feyz alınarak oluşturulmuştur (Özmen, 2016, s. 69).

Adres Address

RumeliDE Dil ve Edebiyat Araştrmaları Dergisi $\quad$ RumeliDE Journal of Language and Literature Studies Osmanağa Mahallesi, Mürver Ciiçeği Sokak, No:14/8 Osmanağa Mahallesi, Mürver Çiçeği Sokak, No:14/8 Kadıköy - İSTANBUL / TÜRKIYE 34714 Kadıköy - ISTANBUL / TURKEY 34714 e-posta: editor@rumelide.com e-mail: editor@rumelide.com, tel: +90 505 7958124, +90 216773 o 616 phone: +90 505 7958124, +90 216773 o 616 
486 / RumeliDE Journal of Language and Literature Studies 2021.25 (December)

"When I was listening by my eyes": literary synaesthesia in Tevfik Fikret's poetry and Tevfik Fikret as a literary synesthete / G. Nakıboğlu (pp. 468-504)

bir harici tesir arayışına yeltenmemek gerektiğinin yerinde bir örneğini vermektedir. Tanpınar’a göre "eski şiirimiz [...] evvelâ içinde doğduğu ve bağlı bulunduğu içtimaî sistemi ver[mektedir]" ve "eski edebiyat her noktası birbirine cevap veren kapalı, yukarıdan aşağıya doğru düzenlenmiş bir âlemin ifâdesidir”. Nitekim "Şair bu mutlaktan çıkar çıkmaz duyularının adamı ol[maktan]” kaçamayacaktır. Tanpınar’a göre işte Nedim'de artık bariz şekilde görülen bu değişimin başlangıç noktası içtimai mevkiine, farklı meziyetlerine ve devrine nispetle ferdin ta kendisidir (Tanpınar, 1997, s. 10). Tanpınar'ın işaret ettiği Nedim'de görünür hâle gelen değişimin ve duyulara yönelişin neticelerini Batı etkisinde gelişen Türk Edebiyatı'nda farklı tezahürleriyle görmek mümkündür. Söz konusu şiir cephesinde duyular olduğunda, Sebk-i Hindî’nin bariz etkilerini ve değişimi ivmelendiren etkisini göz ardı etmemek ancak bu dış tesirin de kökünde bir iç temayülün ve değişimin ayak izlerini aramak ve nihayetinde değişmekte olan insana varmak tabiidir. Sebk-i Hindî akımı etkisindeki şiirden Servet-i Fünûn Şiiri ile İkinci Yeni Şiiri arasında çizilecek hayali bir birleştirici hat, benzeri etkilerin ve etkilenişlerin gerek dil ve şiir gerek his gerek fikir gerekse duyular noktasında şairleri nasıl yönlendirdiğini anlamayı kolaylaştıracaktır. Bu etki hattının aslında bir tepki hattı olduğunu ve asıl etkenin ise Sebk-i Hindî öncesine ya da o döneme sırlı olduğunu unutmamak gerekir.

Servet-i Fünûn şairlerinden, hemen daima, duyguları ve duyuları öne çıaran tabiatlarıyla edebiyat tarihinde bahsedilmektedir. Kaplan (2007)'a göre yönünü Batı'ya dönen Türk şiirinde "soyut düşünceden duygu ve duyu planına; hayal âleminden gerçekler dünyasına doğru” ilerlemenin üç aşaması söz konusudur; ilk aşama Şinasi ve Namık Kemal'in çizdiği "prensip mahiyetinde düşünceler"den ibarettir. İkinci aşamayı Abdülhak Hamid'in "büyük ihtiras ve felsefîleştirilmiş ıztırapları" oluşturur. Üçüncü aşamaya Recaizade'nin santimantalizmi ve ara nesil şairlerinin "küçük duygu tasvirleri" ile geçilmekte nitekim bu aşamanın devamını getiren, duyguyu "tam mânasıyla" tahlil edebilen Servet-i Fünûncular olmaktadır. Kaplan'a göre bu topluluğun mensuplarının en önemli ve ortak özelliği yakaladıkları "yeni bir duyuş tarzı"dır, "bu duyuş tarzının belirli vasfı hastalık derecesine varan bir nevi aşırı duyarlılıktır” (Kaplan, 2007, s. 41-43). Kaplan’ın ifade ettiği gerçeği kavrama yöntemindeki değişiklik maddî gerçekler olarak nesneyi kavrama noktasında duyuların öne geçmesini bizatihi açıkladığı gibi tabiatı daha önce aksettirilmediği biçimde kimi zaman korkutan ya da görülmek istenmeyen yönleriyle, örneğin bilumum haşeratın membal olarak yeni algılayış şeklini de izaha yardımcı olur. Duyuların yönlendirdiği algının aşırı duygulanımları ve duyarlılığı körüklediği, marazi duyguların duyusal algı üzerinde şekillendirici etkiler gösterdiği Servet-i Fünûn dönemi, şairin sürekli titreyişler, inleyişler, içlenişler ardına saklanarak gerçeğe ancak çekingen biçimde yaklaşabildiği ama duyulardan hareketle kavranabileceği düşünülen gerçekten yine de vazgeçemediği bir dönemdir.

Bireyin kendinde, toplumda ve tabiatta keşfe çıktığı gerçeklik, dönemin gerçek algısındaki yavaş bir değişimin yansıması olarak okunmaya müsaittir. İdealdeki gerçekliğin keşfi yerini ağır ağır maddî gerçekliğin keşfine terk ederken dönem şiirinde bu değişimin çeşitli yansımaları görülmeye başlamaktadır. Ancak nesnel algı ile öznel algı arasındaki yarışıysa öznel algı kazanarak hızlı aşamalar kat edilmek suretiyle öznel algının sınırlarının genişletilmesine yönelik adımlar atılmakta ve bedene dayalı öznel algının zaferi böylelikle ilan edilmektedir. Bedensel algının yönlendirdiği duygu tezi; içsel, ruhî keşfin yönlendirdiği duygu tezinin yerine geçirilmektedir. Bu yeni gelişmekte olan gerçeklik anlayışı elbette ki kavrayıştaki keskin bir dönüşümü haber vermektedir. Duyularla duygular arasındaki bu yeni mutabakat, Servet-i Fünûn poetikasının merkezine usulca yerleşmektedir. Servet-i Fünûncuların eserlerinde ortak olarak "hakikat ve hayal tezadı"nın (Kaplan, 2007, s. 57) görüldüğü kanaati hâkimdir. Bahsi geçen hayal ile klasik şiirin hayali arasında büyük bir farklılık olduğu öncelikle tespit edilmelidir. Klasik şiirin hayali ruhî keşfin etkisiyle idealist gerçekliğin sınırları dahilinde ve onunla bağlantılı duygular hattında şekillendirilirken yenileşmekte olan şiirin hayali, duyularla algılanan gerçeklik ve bu

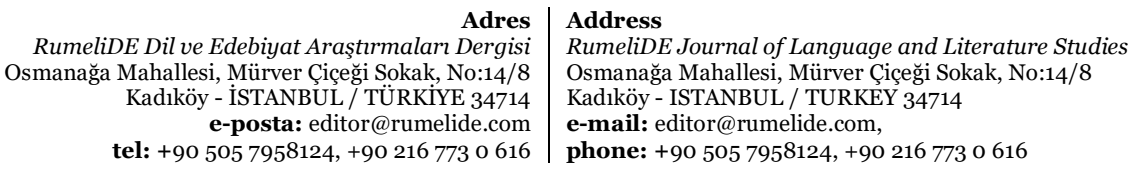


algılanan gerçekliğin yönlendirdiği duygular hattında gelişmektedir. Aslında ortada bir tezat değil birbiriyle uyumlu yeni bir gerçeklik anlayışı ve bu anlayışın yönlendirdiği bir hayal kurma biçimi vardır. Sonuçta Servet-i Fünûncuların yüzleşmeye cesaret ettikleri ya da ondan kaçmaya meylettikleri gerçeklik ve bu gerçeklikten kaçarak sığındıkları ve aynı gerçek tanımı dahilinde oluşturulmuş hayal iklimi ile klasik şiirin gerçek tanımı ve şairlerin onun etkisinde şekillendirilen ve teneffüs ettikleri hayal atmosferi birbirinden tamamen farklıdır. Gerçek tanımı varlık tanımını kapsadığından ve hayal, var olma ihtimali dâhilinde şekillendirilebildiğinden hayal, gerçek tanımının tahakkümü altına girmek zorundadır. Şiirin imge cephesi de dil cephesi de aynı tanımın sınırlarına uyma mecburiyetindedir.

İlhan Berk (2019)'e göre "Divan şiiri ele aldığı konuları işlerken, Batı şiirinin gerçek anlayışından ayrı bir yol tutma[maktadır]”, "Divan ozanı, sözden kaçar, gerçeğin betimsel olmayan, öze dönük yönüne bağlıdı»", tabiatı kendince bir seçime tâbi tutarak ayıklamaktadır, sonuç olarak onun "bakışı" Mallarmé, Valéry, Poe, Rilke, René Char, E. E. Cummings’in "gerçeğe bakışlarından" farklı değildir. Gerçeğe "[s]özcükler, imgeler, çağrışımlar, simgeler üzerine kurulmuş bir yoldan, bir mecazlar dünyasından" yani "bir mecaz evreninden bakar"; bu bakış onu Batılı meslektaşlarından uzaklaştırmayıp aksine onlara yaklaştırmaktadır (Berk, 2019, s. 192-193). İlhan Berk’in bahsettiği gerçek, her iki şiir için de doğrudan maddi olan gerçeğe bağlı bir gerçeklik anlayışı dahilinde tanımlandığından Divan şairinin gerçeğe yaklaşımı ile Batılı şairin gerçeğe yaklaşımı arasındaki fark görülememektedir. Farklı bir açıdan konuya yaklaşan Hasan Akay'ın tespitleri ise şöyledir: Cenap Şehabettin "tabiatı temâşa ederek orada görülen işaret ve sembollerin mânevî ve aşkın kaynaklarını keşfe çıkan eskilerin tam tersine mânevî zeminden yoksun şeyleri sırf estetik bakışla keşfe çıkar, kendi ruhunu, hattâ 'rûh-ı tabiat' dediği şeyi temâşa eder ve ötesine geçemez", şair "din-dışına itilmiş tabiata dînî bir gerçeklik kazandırmak ister" yani "şair, nesnel gerçeklik denen şeyi kendisinin ötesine geçen aşkın bir gerçekliğin sembolü olarak idrak etmediği halde bunu kutsal kılmak zorundadır. Baudelaire de kendisine 'şeytan' der ve bu, şeytanın kendi içinde idrak edilmiş olan hâli ile beliren sembol, mistiklerin aşkın (transandantal) sembolleriyle zıttır; bu sebeple de sembollerin kaynağı şuuraltında aranmaktadır" (Akay, 1998, s. 96-97). Akay, tabiatın maddî gerçekliğinin din-dışına itilmesi ardından şairin ona mistik bir gerçeklik kazandırmaya çalıştığını yani ilk gerçeklik anlayışından sadece dinin mistik yaklaşımının eksiltilip yerine yeni ve dinî olmayan suni mistik bir yönelimin ikame edildiğini ancak gerçek anlayışının korunduğu iddiasıyla bu makalede savunulan görüşten ayrılmaktadır. Oysa asıl fark, maddi gerçeği kavrayıştaki gerçeklik algısını şekillendiren gerçek tanımına bakıldığında bariz şekilde ortaya çıkmaktadır. İşte Servet-i Fünûn şiirinin asıl yeniliği, gerçek tanımında başlayan bu değişim dâhilinde aranmalıdır. Nitekim tabiatı olduğu haliyle aktarmak Servet-i Fünûn şairlerini Parnasizme götürürken "tabiatı ruhlarının aynası olarak görmeleri ise sembolizme götürm[ektedir]” (Şahin, 2006, s. 139). İşte bu türlü bir kavrayışın her iki cephesinde de ister istemez maddî olan yani nesne tüm dolayımlamaların, yansımaların ve anlamın, duyguların üzerinden türetildiği, sağlandığı temel öz, kaynak hâline gelmekte; duyularsa bu kaynakla bağlantının vazgeçilmez unsurları olarak öne çıkmaktadır. Sonuçta artık duygulardan, hayallerden bahsederken bu kaynakla kurulan ilişki zikredilmese de hep devrede kalmaktadır. Tevfik Fikret'in şiirlerinde bu yeni gerçek tanımının ve gerçeği kavrayış biçiminin izleri gerek duyu gerek duygu ve hayal gerekse fikir cephesinde açıkça görülebilmektedir.

\section{Tevfik Fikret'in ilk şiirlerinde edebî sinestezi}

Tevfik Fikret’in Klasik Türk şiiri zevkine bağlı olarak kaleme aldığı ilk şiirlerinde edebî sinestezi örneklerinin bulunup bulunmadığını tespit etmek, edebî sinestezinin onun şiirine doğrudan Batı şiiri etkisiyle mi yoksa başlangıçta Klasik Türk şiiri ve Sebk-i Hindî akımı etkisiyle mi girdiğini anlamaya yardımcı olması dolayısıyla ayıı bir başlık dâhilinde ele alınmaktadır. Ancak bahsi geçen ilk şiirlerini

\footnotetext{
Adres | Address

RumeliDE Dil ve Edebiyat Araştırmaları Dergisi $\quad$ RumeliDE Journal of Language and Literature Studies Osmanağa Mahallesi, Mürver Çiçeği Sokak, No:14/8 $\quad$ Osmanağa Mahallesi, Mürver Çiçeği Sokak, No:14/8 Kadıköy - ÍSTANBUL / TÜRKIYE 34714 Kadıköy - ISTANBUL / TURKEY 34714 e-posta: editor@rumelide.com e-mail: editor@rumelide.com, tel: +90 505 7958124, +90 2167730616 phone: +90 505 7958124, +90 2167730616
} 
488 / RumeliDE Journal of Language and Literature Studies 2021.25 (December) "When I was listening by my eyes": literary synaesthesia in Tevfik Fikret's poetry and Tevfik Fikret as a literary synesthete / G. Nakıboğlu (pp. 468-504)

yazarken Tevfik Fikret’in Batı şiirinden tamamen uzak olduğu gibi bir yanılgıyla bu şiirlere yaklaşılmadığı belirtilmelidir. Zaten onun Rübâb-ı Şikeste'den önce yazdığı şiirlerinin sadece bir kısmı klasik zevke tâbidir, bazıları ise yeni teşekkül eden zevk dairesine yakındır ve klasik zevk dairesindeki şiirlerini yazarken de yeni şiir zevkini yansıtan dönem şiirlerinden haberdardır.

Şairin ilk şiirlerinde tabiatı farklı duyularla aynı anda birlikte algılama eğilimi dikkat çekicidir. Kokular, renkler, sesler öne çlkar ve özellikle bu duyular beraberce algılanır, dokunma duyusu ise genellikle geride kalır çünkü şair hep uzaktan algılamaktadır; nesneyle temastan kaçınır, nesneye dokunmak onun için alışılmadık bir durumdur. Ancak farklı duyulara ait algıların birlikteliği ya da eş zamanlılığı sinestezi ile karıştırılmamalıdır çünkü burada duyuların karşılıklı olarak birbirlerini tetiklemeleri söz konusu değildir. Sosyal yaşamdan bireyin kaçarak sığındığı tabiata dair ilk metaforların Tevfik Fikret’in şiirinde bu dönemde kullanılmaya başlandığını tespit eden Bayrak, ilk tabiat metaforunu tespit ettiği şiir olarak "Sitâyiş-i Hazret-i Şehriyârî"yi zikretmektedir (Bayrak, 2013, s. 230). Tabiat metaforları bilişsel sistemin bedensel deneyime dayalı düşünme eğiliminin bir göstergesi olarak Fikret’in şiirinde gittikçe artarak ve duyu-duygu hattının somutlaştırılması eğilimi dâhilinde yer etmeye başlamaktadır. İlk dönem şiirlerinde metaforlar da dahil olmak üzere farklı duyusal algıları birlikte kullanarak şairin tabiatı kavrayış biçimi önem arz etmektedir.

İlk şiirleri incelendiğinde özellikle düşün-duyumun öne çlktığı görülmektedir. "İlk Sâniha”, "Bahar" şiirleri, şairin yüksek sinesteziyi ilk kullandığı şiirleridir, bu şiirler 1304, 1307 tarihlerinde yazılmıştır. İlk şiirlerde tespit edilen düşün-duyum örnekleri şunlardır: "lezzet-i hulyâ", "şemîm-i rûh", "Acı bir lezzet-i muhabbettir", "ezhâr-ı safâ", "kitle-i ye's", "Dondu kalbimde ağlayan heyecân", "cenâh-1 gayret", "evc-i âmâl", "nevmîd bir sükûnetle/ Sönmek", "Rûhum sehâbelerden alır șemme-i türâb", "bî-tâb enzârım", "nazra-i ülfet", "Söz gölgesidir tahassüsâtın" (Fikret, 2020, s. 30, 51, 105, 126, 171, 174, 188, 206, 209, 226, 227). Hülyanın lezzeti, muhabbetin lezzeti, heyecanın donması, gayretin kanadı, emellerin zirvesi ve bunun gibi düşün-duyum örnekleri arasında sıfat tamlaması, isim tamlaması yanında eylem aktarmaları da bulunmaktadır. Duyuları tetikleyerek harekete geçiren kavramların fikrî olmaktan ziyade duygusal ve manevî olduğu görülmektedir. Tevfik Fikret özellikle yüksek sinestezi (düşün-duyum) söz konusu olduğunda, Sebk-i Hindî akımının ve genel olarak klasik şiir zevkinin açık bir şekilde tesiri altındadır. Bu etkinin Batı şiiri ile ilişkisi ise yalnızca dolaylı olarak bulunmaktadır. Özellikle kaynak olan duyguların hedef olan duyulara aktarımı ve duyuları tetiklemesi, içsel bir etkiyi aşikâr etmekte ve bu içsel gücün ilk dönem şiirlerinde bariz şekilde öne çıktı̆̆ı anlaşılmaktadır.

Şairin ilk şiirlerinde tespit edilen zayıf sinestezi örnekleri şunlardır: "fikr-i leb", "tatlı hayâl-i emelnüvâz!", "derin serâb”, "parlayan hissler" (Fikret, 2020, s. 32, 132, 227). Bilindiği gibi zayıf sinestezide düşün-duyum örneklerinden farklı olarak kaynak duyusaldır. 'Dudağın fikri' ifadesi dışında fikirle ya da düşünceyle ilişkili bir kavramın sinestetik ifadelerde hedef alana yerleştirilmediği görülmektedir. Düşün-duyum örneklerindekine benzer şekilde hedeflenen hep duygulardır. Zayıf sinestetik metaforlar, sonraki dönemde düşün-duyum türündeki metaforlara rakip hâle gelecek ve duyudan hareketle duygulara ve kavramlara gitme şairin şiir ideali doğrultusunda öne çıkacaktır.

İlk şiirlerde güçlü sinestezi ifadelerinin sayısı beklenenden oldukça fazladır. Duyu alanları arasındaki aktarımlara sinestetik ifadeleri en sık kullanılandan en az kullanılana göre şöyle sıralamak mümkündür:

1.Görme->işitme: "Ey nağmelerle besleniyorken hamûş u târ", "güzel lafz", "lisân-ı ezhâr”, "güzel terâne” (Fikret, 2020, s. 94, 100, 147, 218).

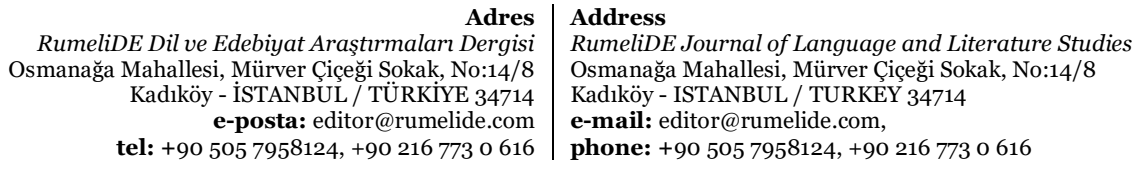



(468-504. s.)

2.Dokunma->görme aktarımı: "bir donuk şafak”, "dondu gözyaşım”, "nazra-i sengîn”, "Donuk ziyâlı” (Fikret, 2020, s. 94, 130, 171, 217).

3.İşitme->görme: "Pür-zemzeme- bir bahâr-1 vuslat/ Eylerdi önümde haşr-i ezhâr" (Fikret, 2020, s. 220).

4.İsitme->koklama: "şemme-i lisân" (Fikret, 2020, s. 126).

5.Görme->koklama: "muanber nücûm” (Fikret, 2020, s. 193).

6.Koklama->görme: "neye baksan lâtîf ü muanberdir"9 (Fikret, t.y., 261).

7.Tatma->görme: "tatlı bakış" (Fikret, 2020, s. 211).

8.Görme->dokunma: "şu’le-i nigâh”, "Erir elvânı sanki eşyânın” (Fikret, 2020, s. 214).

9.Dokunma-> tatma: "zehr-i harâret”, "donuk dîdelerin", (Fikret, 2020, s. 209, 215).

Tevfik Fikret’in ilk dönem şiirlerinde beklenmedik bir şekilde sinestezinin sıfat tamlamalarının yanında eylemlere de kaydırıldı̆̆g görülmektedir. Nağmelerle beslenme, gözün söylemesi, renklerin erimesi, gözyaşının donması, bakışla amber kokusu almak, hoş seslerin (zemzeme) çiçekleri toplaması gibi ifadelerde sinestezinin eyleme kaydırılması dikkat çekicidir. Sinestetik ifadelerde en çok tercih edilen kaynak alan görme, onu takip eden duyu alanı ise dokunmadır; en çok tercih edilen hedef alan görme, onu takip eden ise koklamadır. Görme->işitme aktarımı ile dokunma->görme aktarımı hemen hemen aynı sıklıkta kullanılmaktadır. Görme ile işitme, duyular hiyerarşisinde yakın duyular olmasına nazaran dokunma ve görme uzak duyulardır. Tsur'a göre yakın duyular arasındaki aktarımlar zıt ve uyumsuz nitelikleri uzlaştırarak güçlü bir duygusal etki ortaya çıkmaktadır, aktarımlar uzak duyular arasında gerçekleştiğindeyse uyumsuzluk vurgulanarak nükteli bir etki hedeflenmektedir (Tsur, 2007, s. 49). Tevfik Fikret'in ilk şiirlerinde duygusal etkinin ortaya çıarılmasında yakın duyular arasındaki aktarımlar kadar uzak duyular arasındaki aktarımlardan da faydalanılmakta, uzak duyular arasındaki aktarımların nükteli bir amaç gözetilerek oluşturulmadığı aksine güçlü etkiler tesis etmek üzere zitlıkların ve uyumsuzluğun vurgulanması yoluna gidildiği görülmektedir.

Tevfik Fikret, güçlü sinesteziyi ilk olarak Mirsad'da 1307'de yayımlanan "Girye-i Mâtem" şiirinde "Gözüm, sen söyle." (Fikret, 2020, s. 86) şeklinde kullanmaktadır. Mehmet Kaplan (2007), "Girye-i Matem" şiirinin Tevfik Fikret'in birkaç sene sonra oturmaya başlayacak üslûbunun habercisi olduğunu belirtmektedir, o döneme kadar "silik ve klişe" tabiat tasvirleri kullanan ve "dış âlemi şiirine aksettirmek maharetini kazanama[yan]" şair, bu şiirle birlikte üslûbunun "zenginleşmekte ve açılmakta" olduğunu göstermektedir. Kaplan, 1309-1311 (1893/1894- 1895/1896) arasındaki dönemi "Batı edebiyatı ile yakından temas" dönemi olarak tespit etmekte, bu dönemde Malumat'ta şiirleri yayımlanan Tevfik Fikret'in Recaizade'nin şiirini ancak hakkıyla kavrayabildiğini vurgulamaktadır. Kaplan, aynı zamanda bu dönemin şairin şiirde eksik olan pitoresk unsurun farkına vardığı ve "göz"e verdiği istisnai kıymeti açıkça zikrettiği bir dönem olması dolayısıyla da bilhassa önem arz ettiğine işaret etmektedir (Kaplan, 2007, s. 78-79). Halk şiiri dizelerini hatırlatan "Girye-i Mâtem" şiirindeki güçlü sinestetik ifadede, sinestezinin sıfat tamlamasından eyleme kaydırılması şairin ilk şiirlerinde kullandığı güçlü sinestetik ifadelerin kökeninde geleneksel şiirin bulunabileceğine işaret etmektedir. Kaplan'ın Batı şiiriyle temasın

9 Bu mısra Parlatır ve Çetin tarafından "Latîftir neye baksan, latîf ü muğberdir” şeklinde okunmuştur (Fikret, 2020, s. 193).

Adres Address

RumeliDE Dil ve Edebiyat Araştırmaları Dergisi $\quad$ RumeliDE Journal of Language and Literature Studies

Osmană̆a Mahallesi, Mürver Çiçeği Sokak, No:14/8 Osmanağa Mahallesi, Mürver Çiçeği Sokak, No:14/8

Kadıköy - İSTANBUL / TÜRKIYE 34714 Kadıköy - ISTANBUL / TURKEY 34714

e-posta: editor@rumelide.com $\quad$ e-mail: editor@rumelide.com,

tel: +90 $5057958124,+90216773$ o 616 phone: +90 505 7958124, +90 2167730616 
490 / RumeliDE Journal of Language and Literature Studies 2021.25 (December) "When I was listening by my eyes": literary synaesthesia in Tevfik Fikret's poetry and Tevfik Fikret as a literary synesthete / G. Nakıboğlu (pp. 468-504)

arttığı dönem olarak işaret ettiği tarih olarak 1309 kabul edilecek olursa bu tarihten önce Tevfik Fikret’in ilk şiirlerinde kullandığı gerek güçlü ve zaylf sinestetik metaforlarda gerekse yüksek sinestetik (düşünduyum) metaforlarda açıkça görülen şairin dildeki yerleşik sinestetik ifadelerden ve Türk Halk şiiri ile Klasik Türk şiiri kaynaklarından beslendiğidir. Bu doğrultuda Tevfik Fikret’in şiirinde edebî sinesteziden bahsedilirken sadece Batılı kaynaklara işaret edilmesinin hatalı olduğu ortaya çıkmaktadır. Bu tespitin yanı sıra, kesin olarak söylemek mümkün olmasa da Tevfik Fikret’in ilk şiirlerinde, Rübâb-ı Şikeste ve sonrasında yazdığı şiirlerden çok daha az sinestetik ifadelere müracaat etmesi şairin doğal bir sinestet olmadığına yorumlanabilir ancak makalenin giriș kısmında da belirtildiği üzere nörolojik sinestezi ile dilsel ve edebî sinestezi farklıdır; dolayısıyla bu yorum, sadece bir sezgi olarak kalmak durumundadır. Şairin resimle olan ilişkisinin, resimle şiiri türlü yollarla (kartpostallar altına şiirler yazmak, tablolara şiirler adamak vb.) buluşturma tutkusunun, göz-söz birlikteliğini yakalama azminin onu edebî sinesteziyi sahiplenmekte cesaretlendirdiğini ve zamanla üslubunun ayrılmaz bir parçası hâline gelmesini sağladığını söylemekte ise hiçbir sakınca yoktur.

1311 tarihli "Bir Söz" şiirinden alınan aşağıdaki parçada sinestezinin nasıl duyulardan duygulara ve ruhî boyuta geçiş için kullanıldı ̆̆ı, ifadelerin genel olarak yüksek sinestezi olarak kabul edilen düşün-duyuma bütünlüklü bir şekilde evrilmesinin amaçlandığı rahatça görülebilmektedir:

"Ezhâr-1 safâdan duyulur şemme-i cennet;

Ol şemme-i lisândır ki anınla eder elbet

Her tâze çiçek bir çiçeğe aşkını ilân.

Şâ’ir bu lisânın da duyar zevkini ammâ,

Bulmaz o sözün rûhunu bir nağmede aslâ!” (Fikret, 2020, s. 126)

Safânın çiçeklerinden alınan Cennet kokusu, koku lisanıyla taze çiçeklerin aşkını ilan ederken şair bu lisanın zevkini duysa da o sözün ruhunu hiçbir nağmede bulamaz. Koku duyusunun işitmeye aktarılması yani güçlü sinestetik metafor, sözün ruhuna yükselmek için bir aşama, geçiş kapısı olarak kullanılmaktadır. İlk dönem şiirlerinde duygusal ve ruhî olana yükselme ideali doğrultusunda duyulardan faydalanılmaktadır. Bu Romantizm akımının yücelme (sublimasyon) teziyle örtüşen bir yaklaşımdır. Bu etkinin kaynağını tespit etmek üzere Recaizade Mahmut Ekrem'in ve özellikle Abdülhak Hamid Tarhan'ın şiirlerine ayrıntılı olarak bakılması gerekmektedir ancak klasik şiir zevkinin etkisi de göz ardı edilmemelidir. Ruhî olana yükselmenin/yücelmenin anahtarı şiirde, duyular eşiğinden geçme, duyular eşiğini aşma olarak tanımlanmaktadır. Bu dönemde Tevfik Fikret’in şiirine edebî sinesteziyi taşıyan şiir güzergâhları olarak klasik şiir zevkinin ve halk şiirinin yanına Batı şiirinden dolaylı olarak aktarılan romantik tesiri de eklemek gerekmektedir.

\section{Rübâb-ı Şikeste'de edebî sinestezi}

Rübâb-ı Şikeste'de, sinestezinin tüm türlerinin yaygın bir şekilde kullanılmaya başlandığı ve Tevfik Fikret'in üslubunun bir parçası hâline geldiği görülmektedir. Bu kitapta yer alan şiirlerde en sık rastlanan sinestezi türü duyular arasında gerçekleşen aktarımların esas olduğu güçlü sinestezidir. Dilbilim çalışmalarında genelde sadece sıfat tamlamalarına bakılması tercih edilirken edebî bir kaygıyla sinesteziden hâsıl olan anlamı tam olarak yakalayabilmek için sıfat tamlamalarının bağlı olduğu diğer tamlamalar da dikkate alınmakta; isim tamlamaları, fiiller, isim-fiiller, sıfat-fiiller ve zarflar da incelemeye dahil edilmekte, anlamın tam olarak ortaya konulabilmesi için sinestetik ifadeyi güçlendiren diğer sıfatlar veya zarflar, fiiller de yeri geldiğinde belirtilmekte ve sinestetik metafor birlikte bulunduğu ve sinestetik anlamın ortaya çıkmasını sağlayan çeşitli yapılardan ayrılmamakta, üç ya da dört unsurdan

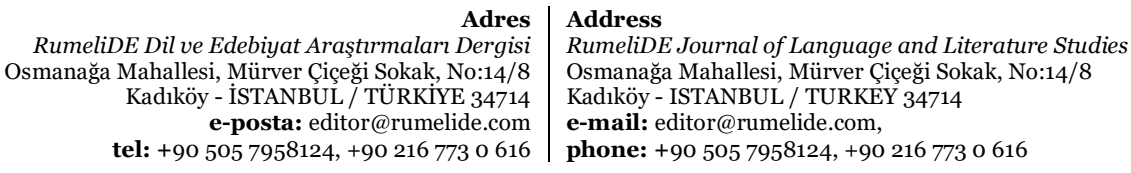



(468-504. s.)

oluşan sıfat tamlamaları parçalanmamaktadır. Güçlü sinestezi örneklerinin hangi duyular arasında aktarımla gerçekleştiği ayrı ayrı gösterilmek suretiyle Ullmann’ın işaret ettiği duyular hiyerarşisinde aktarımların genel yönü tespit edilmektedir. Bu tespitler, daha sonra Kumcu (2021)'nun Türkçede duyular hiyerarşisi üzerine yaptı̆̆ı inceleme ile karşılaştırılmaktadır.

Rübâb-ı Şikeste’de tespit edilen güçlü sinestezi türündeki ifadeler şunlardır:

1.Görme-> işitme aktarımı: "bu kirli, bu yırtık sadâ" (Fikret, 2020, s. 269), "teneffüs-i ezhâr" (s. 279), "bu şi’r-i siyah" (s. 291), "bir küçük nefes" (s. 305), "aksedip hazin, memdûd/ Yattı öksüz bu aksi dinleyerek" (s. 306) [uzun ses], "savt-ı billûr" (s. 329), "sesinde öyle derin bir inilti” (s. 330), "nağme-i rengîn" (s. 334), "mülevven sürûd-ı şûh-ı bahâr" (s. 347), "ben gözlerimle dinlerken" (s. 370), "Hazîn terâne-i billûru bir küçük derenin" (s. 375), "Bir samt-ı siyeh-reng” (Fikret, 2020, s. 386).

2.İşitme->görme aktarımı: "çehre-i eş’ârım" (Fikret, 2020, s. 231), "Yüzünde giryeli, muzlim, boğuk şikâyetler" (s. 244), "likâ-yı hamûşunda" (s. 263), "zılâl-ı hâmuş" (s. 271), "mir’ât-ı sem-âlûde" (s. 296), "Pür-zemzeme bir cevf-i ziyâ-dâr" (s. 315) [Hoş seslerle dopdulu (işitme) bir ışıklı boşluk (görme)], "gırîv-i mûhiş-i emvâc ağır ağır sönerek" (s. 326), "Pervâz-ı hamûşânesi" (s. 332), "Baksan, o dudaklardaki âvâz-ı medâyih/ Hep kendi sesindir” (Fikret, 2020, s. 335).

3.Dokunma->görme aktarımı: "Soğuk bir levha" (Fikret, 2020, s. 284), "lem’a-i pâ-mâl” (s. 293), "soğuk gölge” (s. 300), "bürûdetli manzara” (s. 302), "Soğur, donar, kırılır senden ayrllınca nazar” (s. 317), "muhrik parıltılar" (s. 330), "efsürde bir sehâb-1 kesîf" (s. 350), "sıcak levn" (Fikret, 2020, s. 383).

4.Görme-> dokunma aktarımı: "zîr-i ham u tâbında", "ser-i eşcârı örtüyor zulemât" (Fikret, 2020, s. $334,366)$.

5.Dokunma-> işitme aktarımı: "hararetli nutk", "nağme-i sûzân", "Derin gurrende" (Fikret, 2020, s. 241, $334,387)$.

6.Tatma->görme aktarımı: "tatlı giryelerin”, “Acı bir levha” (Fikret, 2020, s. 314, 342).

7.Tatma-> dokunma aktarımı: "ten-i şirin”, "bir acı lerziş" (Fikret, 2020, s. 279, 283).

8.Tatma->işitme aktarımı: "tatlı bir sadâ" (Fikret, 2020, s. 277).

9.Tatma-> koklama aktarımı: "Acı bir nefha” (Fikret, 2020, s. 321).

10.Koklama->işitme aktarımı: "mu'attar müşâfehât-ı riyâh” (Fikret, 2020, s. 347).

11.Koklama-> dokunma aktarımı: "sîne-ı muattar" (Fikret, 2020, s. 270).

12.Görme ve dokunma->koklama aktarımı: "nefha-i serd ü siyeh-reng” (Fikret, 2020, s. 284).

13.Görme ve koklama->tatma aktarımı: "Bir sâf u mu'anber/ Zehr-âbe-i nûş̂n”" [Saf ve amber kokulu hoşa giden acı/ zehir gibi su] (Fikret, 2020, s. 334).

14.İşitme->dokunma->görme aktarımı: "bir köy bu sükûnetle ezilmiş" [Sessizlikle (işitme) ezilmiş (dokunma) bir köy (görme)] (Fikret, 2020, s. 348).

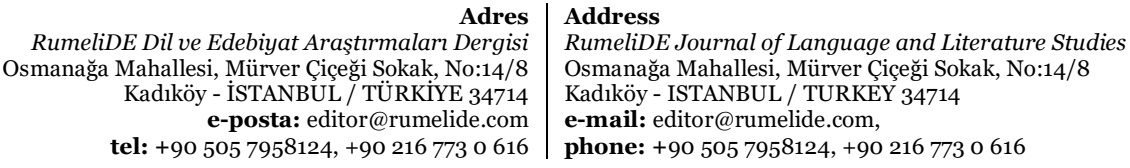


492 / RumeliDE Journal of Language and Literature Studies 2021.25 (December) "When I was listening by my eyes": literary synaesthesia in Tevfik Fikret's poetry and Tevfik Fikret as a literary synesthete / G. Nakıboğlu (pp. 468-504)

15.İşitme->görme->dokunma aktarımı: "Sarıyor leblerinde pür-şu'le/ Bir figân-ı garâm-ı şefkatle" [Büyük bir aşkın feryadını (işitme) alev-ışık dolu (görme) dudaklarında sarıyor (dokunma)] (Fikret, 2020, s. 329).

16.Tatma->dokunma->koklama aktarımı: “Acı bir nefha-i bürûdet” [Acı(tatma) bir soğuğun (dokunma) güzel kokusu (koklama)] (Fikret, 2020, s. 276).

17.İ̧itme->görme->dokunma->tatma aktarımı: “Nutkundan uc,an zehr-i bürûdet” [Sözünden (işitme) uçan (görme) soğuğun (dokunma) zehri (tatma)] (Fikret, 2020, s. 386).

Rübâb-ı Şikeste'de duyular arası aktarım listesi ${ }^{10}$ en sık kullanılan aktarım türünden en az kullanılana doğru yukarıdan aşağı oluşturuldu. Listeye ${ }^{11}$ göre en sık görülen aktarım tipi görmeden işitmeye doğrudur. İşitmeden görmeye aktarımların sıklığının görmeden işitmeye aktarımların kullanım sıklığına oldukça yakın olduğu görüldü. Bu netice, bilişsel haritalamanın en çok yakın duyular arasında gerçekleştirildiğini ortaya koydu. Bu açıdan Rübâb-ı Şikeste'nin ilk şiirlerden farklı bir özellik sergilediği belirlendi. Tsur (2007)'a göre yakın duyular arasındaki aktarım duygusal etkiler ortaya çıarmak için kullanılmaktadır. Tevfik Fikret’in edebî sinesteziden güçlü ve yoğun duygusal etkiler yaratmak amacıyla faydalandığı tespit edilmektedir. Kumcu (2021)'nun günümüz Türkçesi derleminde sinestetik metaforlar üzerine yaptı̆̆ araştırmada en sık kullanılan kaynak alan dokunma, ikinci sırada en sık kullanılan kaynak alan ise görme olarak tespit edilmektedir. Tevfik Fikret'in Rübâb-ı Şikeste'deki şiirlerinde en sık kullanılan kaynak alan görme, onu takip eden kaynak alan ise dokunmadır. Bu açıdan günümüz Türkçesi ile yirminci yüzyılın başındaki Türkçenin yakın ya da uyumlu olduğu anlaşılmaktadır ancak Tevfik Fikret’in genel duyusal aktarımda kaynak alan açısından dilin genel eğilimini görme duyusunu öncelemek kaydıyla devam ettirdiği çıkarımı da yapılmalıdır ${ }^{12}$. Kumcu (2021)'nun tespitine göre Türkçede en sık kullanılan hedef alan işitme ve onu takiben görmedir. Tevfik Fikret'te hedef alan tercihinde ilk sırada görme yer alırken ikinci sırada işitme yer almaktadır ${ }^{13}$. Tevfik Fikret’in burada da dilin genel sinestetik yapısıyla uyumlu addedilebilecek bir üslubu benimsediği görülmektedir ancak şair yine görme duyusunu öncelemektedir. Fikret'in hem hedef hem de kaynak alan olarak en çok tercih ettiği duyu görmedir. Bu bulgu, şairin resme olan ilgisi ile uyumludur ve onun edebî sinestezi vasıtasıyla şiirle resim yapmanın farklı bir yolunu daha keşfettiğini ortaya koymaktadır.

Rübâb-l Şikeste'deki sinestetik metaforların çok çarpıcı bir özelliği iki, üç hatta dört aşamalı aktarımlar ihtiva etmesidir. Bu yöntem Servet-i Fünûncuların ve Tevfik Fikret’in duyuları sırasıyla başka duyulara aktararak nihayetinde bir hedef duyuda toplamak için kullandığı enteresan bir yöntem olarak dünyada nadir görülen bir sinestetik metafor türü, edebî sinestezide benzerine az rastlanır mühim bir keşif olarak kayda geçirilmelidir. Şairin bu yöntemin farklı türlerini kullandığı görülmektedir. Şairin bu yöntemi sessiz sedasız hayata geçirmesini ve edebî sinesteziye yepyeni bir yaklaşım getirerek kullanmasını sağlayan Servet-i Fünûn şiirinin benimsediği çoklu sıfat kullanım yöntemidir. Servet-i Fünûncuların

10 Liste hazırlanırken “ağır” kelimesi sözlükte iki anlamıyla iki farklı duyuya hitap etmekte kullanılmakta olup ölü sinestetik metaforların en yerleşik olanlarından biri olduğu için listeye dahil edilmemistir ancak Servet-i Fünûn Edebiyatı döneminde yapılan tartışmalardan hareketle "tatlı" kelimesinin genel olarak ölü bir sinestetik metafor bileşeni olarak görülmesinin karara bağlanmamış olduğu anlaşılmakta olup bu sebeple "tatlı" sıfatının kullanıldığı sinestetik metaforlar listeye dahil edilmiştir. Cenap Şehabettin'in "nûşîn” kelimesi hakkındaki görüşleri ve yorumu için bakını: (Kaplan, 2007, S. 234; Akay, 2020, s. 277-278).

Duyular arası aktarımlarda kullanım sıklığı belirlenirken 11-16. maddeler arasında gösterilen aktarım tipleri sırasıyla tek tek duyular arasında dağıtılarak kullanım sıklıkları belirlenmektedir.

12 Kaynak alan en sik kullanılandan en az kullanılana doğru: Görme (16) > Dokunma (14) >İşitme (12) > Tatma (5) > Koklama (1).

Hedef alan en sık kullanılandan en az kullanılana doğru: Görme (21) > İşitme (15) > Dokunma (5) > Koklama (4) > Tatma (1).

Adres

RumeliDE Dil ve Edebiyat Araştırmaları Dergisi Osmanağa Mahallesi, Mürver Çiçeği Sokak, No:14/8 Kadıköy - İSTANBUL / TÜRKIYE 34714 e-posta: editor@rumelide.com tel: +90 $5057958124,+90216773$ o 616
Address

RumeliDE Journal of Language and Literature Studies

Osmanağa Mahallesi, Mürver Çiçeği Sokak, No:14/8

Kadıköy - ISTANBUL / TURKEY 34714

e-mail: editor@rumelide.com,

phone: +90 $5057958124,+902167730616$ 

(468-504. s.)

"Farsça birleşik sıfat yapma kuralı”nı Türkçeye taşıyarak “Servet-i Fünûn’a özgü birleşik sıfatlar ('vasf-1 terkibîler)” ürettikleri bilinmektedir (Akay, 2020, s. 271). Tevfik Fikret’in musikî gibi bir şiir yazma, şiirde görülmedik tamlamalar üretme heyecanının altında biraz da şiirini farklı türde zenginleştirme ve özgünleştirme yöntemi olarak, daha önce görülmemiş edebî sinestetik metaforlar üretme ve bu metaforlarla şiirindeki yoğun duygusal atmosferi besleme gayretinin yattığı böylece ortaya çımaktadır. Bu yöntemi "katmerli sinestezi" olarak bu makalede adlandırmayı uygun gördük. Tespit edilen katmerli sinestezi türleri şunlardır:

1.Birlikte aktarım: Aynı anda iki farklı duyuya ait sıfatın ortak bir hedef alan üzerine haritalanmasıdır. Örneğin "nefha-i serd ü siyeh-reng" (Fikret, 2020, s. 284) terkibinde görme ve dokunma duyuları beraberce koklama alanı üzerine haritalanmaktadır. "Bir sâf u mu'anber/ Zehr-âbe-i nûşîn" (Fikret, 2020, s. 334) terkibindeyse görme ve koklama kaynak alanlarından duyular beraberce tatma duyu alanı üzerine haritalanmaktadır. Bu örneklerde (yukarıda 12. ve 13. sırada yer alan) birlikte algılamanın birlikte aktarımı da sağladığı görülmektedir. Birlikte aktarım yöntemi edebî sinestezi açısından bakıldığında güçlü sinestetik metaforun farklı duyu alanlarını kapsayacak şekilde genişletilerek daha da güçlenmesine ve etki alanının yayılmasına, duygusal ve kaotik etkinin arttırılmasına yardımcı olmaktadır. Zayıf sinestezi (örneğin “yeşil, tâze bir emel”) ve yüksek sinestezi (örneğin "Elvân ü revâyih/ Kût-ı hevesindir”) dâhilinde de birlikte aktarım örnekleriyle karşılaşılmaktadır.

2.Dolaylı zincirleme aktarım: Seçilen üç veya dört farklı duyu alanının zincirleme bir şekilde birbirine aktarılmasıyla oluşturulan katmerli sinestezi türüdür. Örneğin; "bir köy bu sükûnetle ezilmiş" (Fikret, 2020, s. 348) [bu, sükûnetle ezilmiş bir köy] sinestetik ifadesinde "sessizlikle" ifade edilen kaynak alan işitme duyusu "ezilmek" fiilinden türetilmiş bir sıfat-fiil olan "ezilmiş" sıfatıyla dokunma duyu alanına aktarılmakta ardından dokunma kaynak alanından görülen nesne olarak köye yani hedef duyu alanı olan görmeye yönlendirilmektedir. Yukarıdaki listede 14, 15 ve 16. sırada yer alan dolaylı zincirleme aktarımlar üç unsurdan oluşurken 17. sırada tespit edilen sinestetik metafor dört ayrı unsurdan oluşmaktadır. Ayrıca Tevfik Fikret’in bu dönem şiirlerinde yüksek sinestezi (düşün-duyum), zayıf sinestezi ve güçlü sinestezi türündeki metaforları farklı kombinasyonlarla iç içe geçirerek oluşturduğu farklı dolaylı zincirleme aktarımlar kullandığı da görülmektedir: "Şikeste reng-i sefâlet" ve "garîb gönlü yanık âteş-i zaruret” bu tür dolaylı zincirleme aktarımlarla oluşturulmuş katmerli sinestetik metaforlardır. Bu metaforlar terkipler halinde ilgili başlıklar altında, parçalanmadan, şiirlerdeki hâli korunarak gösterilmektedir.

Tsur, "kaotik aşırı farklılaşma” yı Baudelaire’in "Uyuşumlar” şiiri bağlamında şöyle açıklamaktadır: "[N]esneden ve gestalttan bağımsız görüş ve duyuların kaynaşması sayesinde" "aşağı yönlü aktarımlar tarafından rahatsız edilmeyen, yalnızca doğrulanan, aşırı farklılaşmış kaotik evren[de] mistik-esrik etki [.] kesintiye uğramak yerine pekiştirilir" ve "kaotik aşırı farklılaşma, aşağı doğru aktarımın nükteli etkisini geçersiz kılabilir", bazı durumlarda "aşırı yüklenme” ye sebep olarak bilişsel sistemde aşağıya doğru bir boşaltımı tetikleyebilir (Tsur, 2007, s. 44, 49). Tevfik Fikret’in kullandığı katmerli sinestezinin özellikle zincirleme dolaylı aktarım türündeki örneklerinde uzak duyu alanları arasında hızlı geçişler sağlandığı ve hiyerarşi tablosunda yukarıdan hızla aşağıya doğru inilip sonra tekrar yukarıya doğru çok hızlı bir çıkışla hedef alana ulaşıldığı görülmektedir. Bu türlü bir zincirleme aktarımın bünyesine depoladığı kaotik aşırı farklılaşma nükteli etkiyi ters yüz etmekte aksine beklenenden çok daha yoğun bir duygusal etkinin ortaya çıkmasına hatta bir duygusal kaos ortamının oluşmasına neden olmaktadır. Sinestetik metaforların şiir genelindeki yapıyla özellikle sürekli tekrarlanan inleyişler ve titreyişlerle etkisinin arttırıldığı ve edebî sinestezinin bu vasıtayla tüm şiire yayıldığı görülmektedir. Akpınar’a göre şairin şiirlerinde "titreme imgesi"ni bu kadar sık kullanmasının altında bilinçli bir tercihten ziyade

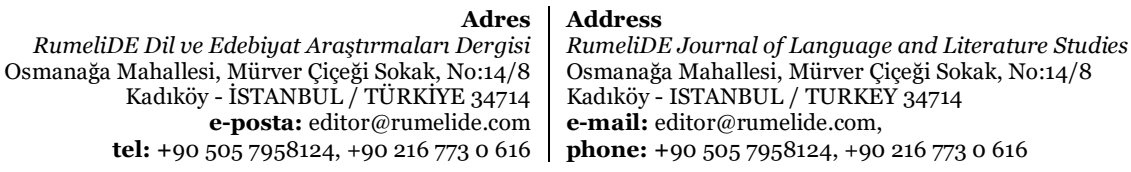


494 / RumeliDE Journal of Language and Literature Studies 2021.25 (December) "When I was listening by my eyes": literary synaesthesia in Tevfik Fikret's poetry and Tevfik Fikret as a literary synesthete / G. Nakıboğlu (pp. 468-504)

psikolojik tabiatın sevki yatmaktadır; şair titreme imgesini kullanarak "bir anlam yoğunluğu sağlamak iste[mektedir]” (Akpınar, 2013, s. 85). Edebî sinestezi söz konusu olduğunda Tevfik Fikret’in şiirlerinde sürekli kullandığı 'titrek', ‘titreşme', 'titreşim' gibi ifadelerin, şiirdeki algılayan özne açısından algının mahiyeti üzerinde gestaltı devre dışı bırakan, nesnesizleşmeye gidişi kolaylaştıran etkin bir faktör olarak ele alınması gerekmekte ve bilinçli bir tercihi yansıtmaktadır.

Tevfik Fikret'in şiirlerindeki titremeyle ilgili ifadeler gerçekçi bir tabloyu adeta izlenimci bir tabloya dönüştürmekte nesnenin keskin ve net hatlarıyla görünmesini engellemekte hatta şiirleri puantalist birer tabloymuşşasına aynı anda beraberce titreşen zerreler ardına saklamaktadır. Böylelikle bütüne dair algııı hafifletmekte ve hatta Dali’nin kürelerine benzer küreler içinde dağıtmakta ve gestalta dayalı algıyı değiştirerek deformasyona uğratmaktadır. Tsur'un işaret ettiği nesnelerin kaynaşmaya engel olan keskin sınırlarını (2007, s. 34) bu titreşimler, şiir genelinde ortadan kaldırmaya yardımcı olmaktadır. Duyuların güçlü sinestezi bağlamındaki her bir çaprazlanmasının etkisi bu titreyişlerle şiir geneline dağıtılıp yayılarak iki olan duyu çaprazlanması sayısını fark ettirmeden üçe yükseltmekte ve her sinestetik metaforun dokunma temelli titremeden hareketle bir basamak yüksekten başlayarak aktarılmasını sağlamaktadır. Sonuç olarak Tevfik Fikret’in şiirdeki bilinçli tercihi, tüm sinestetik metaforların birer dolaylı zincirleme aktarım mahsulü olmasını sağlayarak onların katmerli sinestetik metaforlara dönüşmesini temin etmektedir. Her bir sinestetik metafor böylece onun şiirlerinde bir katmerli sinestezi örneğine evrilmektedir. Tevfik Fikret'in kullandığı katmerli sinestetik metaforlar, şiirlerde "kaotik aşırı farklılaşmayı" doğurmaktadır. Bu tespitlere istinaden bu makalede ilk kez tanımlanan katmerli sinestetik metaforların ve türlerinin Tsur (2007)'un tanımladığı "kaotik aşırı farklılaşma" temininde kullanılan yöntemlerden biri olarak değerlendirilmesi ve bu başlık altına eklenmesi teklif edilmektedir.

Rübâb-ı Şikeste'de sinestetik ifadeler üzerine yapılan incelemenin bir diğer sonucu Tevfik Fikret'in en az sıfatlar kadar sıfat-fiillerden ve fiillerden de sinestetik metaforlarda faydalandığının tespit edilmesidir. Tevfik Fikret'in şiirlerinde sinestezi konu edildiğinde sadece sifatlardan bahsedilmektedir (Kaplan, 2007, s. 234-238) oysa onun enteresan bir biçimde ilk şiirlerinde kullandığı fiillere dayalı sinestetik ifadeler oluşturma eğilimi bu dönemde de sürmektedir. Tevfik Fikret’in şiirlerinde sinesteziden bahsedilirken bu veriler ışığında, bundan sonra, mutlaka fiillerden ve zarflardan hatta bir sonraki dönemde ünlemlerden de bahsedilmesi gerekmektedir.

İlk şiirleri arasında yer alan göz-söz ilişkisinin formülü olarak nitelendirilebilecek gözün kişileştirildiği "Gözüm, sen söyle" (Fikret, 2020, s. 86) ifadesinin bir benzerini şair, Rübâb-ı Şikeste'de "Köyün Mezarlığı" şïrinde "ben gözlerimle dinlerken" (Fikret, 2020, s. 370) şeklinde kullanmaktadır. Görmenin kaynak alan olarak seçimi genel duyusal kaynak alan seçimiyle uyumlu olduğu gibi şairin gözüyle gördüklerini söze dökme çabasının da dile gelmiş ve formülleştirilmiş hâlidir. Bu tespit, Tevfik Fikret’in şiirlerini göstergebilimsel açıdan inceleyen Selçuk Atay'ın görmenin onun şiirlerindeki başat konumuna dair tespitleriyle de uyumludur (Atay, 2019, s. 108). İlk şiirlerdeki söyleme, söze dökme isteğinin daha sonra dinlemeye tevili ise çarpıcıdır. Bu iki ifade aynı duyu alanları arasında aktarımlar ihtiva etmeleriyle benzeşseler de görme duyusunun iki farklı döneme ait iki farklı ifadede, işitme duyusunun iki zıt kutbuna haritalandığını nazarı dikkatten kaçırmamak gerekir. "[B]en gözlerimle dinlerken" ifadesi onun daha sonra yazacağı şiirlerde hem üslubunun bir parçası olan sinesteziyi nasıl kullanacă̆ına hem de örneğin "Sis”te olduğu gibi tabiata, topluma, insana, kendine nasıl yaklaşacağına dair bir temel formül özelliği taşımaktadır ve mutlaka bu doğrultuda da değerlendirilmelidir. Bu temel formüldeki ‘ben’in “gözleri”, şairin ilgilendiği konuya, hep öznel bir şekilde yaklaştığının ve onun maddi gerçeği kavrama biçiminin de anahtarıdır.

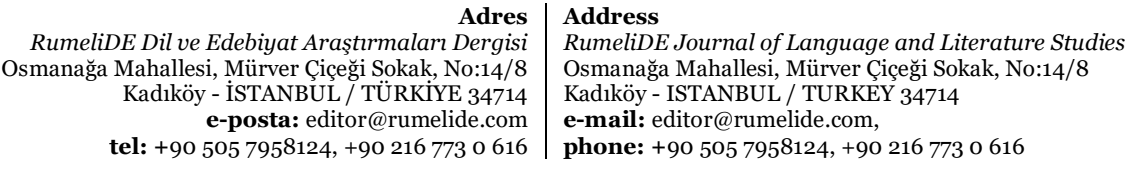


Rübâb-ı Şikeste'de tespit edilen zayıf sinestezi türündeki ifadeler şunlardır: “[B]ir acı vahşet” (Fikret, 2020, s. 247), "hayâl-i sefîd" (s. 243), "acı bir zevk" (s. 245), "en acı, en rûh-gezâ/ Bir ma’îşet” (s. 246), "soğuk terbiye" (s. 246), "bir acı vahşet” (s. 247), "rûh-ı esmer-i şâm” (s. 259), “Gülümsüyordu soğuk bir sükûn-ı vahşetle" (s. 262), "Acı bir nevha-yı teşekkî” (s. 269), "mülevven dem-i şebâb” (s. 271), "acı bir nefha-i bürudet" (s. 276), "Hazîn bir telhî-i nekbet” (s. 284), "acı bir haşyet” (s. 296), "1ztırâb-ı serd" (302), "sâ’ât-ı jeng-âlûd-ı şeb" (s. 303), "Bir siyeh-neş'e" (s. 308), "ümîd-i mücennah" (s. 310), "bu mu'attar harîm-i ilhamın" (s. 316), "hüznü samimî, derin, hafî, ince" (s. 326), "rûz-1 siyahı" (s. 328), "Tâze bir aşk-ı muhtazır" (s. 329), "rûh-ı uryânı" (s. 329), "tatlı zamanlar" (s. 330), "soğuk bir yabancı tavrıyla" (s. 338), "Karanlık bir sabâvet” (s. 340), "ömr-i zehr-âlûd” (s. 340), "mînâ-yı leb-rîz-i sa'âdet", "bir tatlı rü’yâ" (s. 344), "hayâlât-ı siyeh-per" (s. 345), "mülevven sürûd-ı şûh-ı bahâr" (s. 347), "yeşil, tâze bir emel" (s. 352), "mâtem-i sukût" (s. 371), "pek tatlı bir edâ-yı vakûr" (s.376), "En müşâ’şa, tezâd1 ibretsin" (s. 381), "havf-ı siyâh" (Fikret, 2020, s. 386). Tespit edilen zayıf sinestetik ifadelerin genel olarak duygularla ilişkili olduğu ancak mevsim adlarına da yer verildiği görülmektedir, fikirle ilgili kavramlar hedef alan olarak seçilmemektedir. Kaynak alan olarak güçlü sinestetik ifadelere benzer şekilde görme duyusunun öne çıtığı, onu dokunma ve tatma duyularının takip ettiği tespit edilmektedir. Dolaylı zincirleme aktarımın farklı bir türüyle zayıf sinestezi örnekleri arasında da karşılaşılmaktadır. "[S]oğuk bir sükûn-ı vahşet" (Fikret, 2020, s. 262) ifadesinde önce bir yüksek sinestetik metafor kurularak vahşetin sessizliği terkibi oluşturulmakta sonra bu terkip soğuk sifatıyla nitelendirilerek bir zayıf sinestezi örneğine yönlendirilmekte ve dolaylı zincirleme aktarımın hedef ve kaynak alanları arasındaki ilişki bu suretle kurulmaktadır. Bu dönemde, önceki şiirlerine nazaran zayıf sinesteziyi, şairin yüksek sinesteziye rakip olacak şekilde ve çoğu yerde yüksek sinestezi yerine kullanmaya başladığı görülmektedir. Böylece gittikçe artan bir oranda kavramlardan duyuya gidiş yerini düşük sinestezi kapsamında duyulardan kavramlara gidişe bırakmaktadır.

Yüksek sinestezi kapsamında yer alan düşün-duyum ifadelerinin bazıları şunlardır:, "Şikeste reng-i sefâlet" (Fikret, 2020, s. 266), "garîb gönlü yanık âteş-i zaruret" (s. 266), "en mülevven dem-i şebâb" (s. 271), "pür-lehîb-i mihnet” (s. 276), "lerze-bahş-i derûn” (s. 279), "serdî-i muhabbet” (s. 276), "ezhâr-1 hâtırâtile, pür-şemme-i visâl" (s. 277), "gûş̧-1 ruhumda" (s. 300), "Şeb-i nîlî-i nisân" (s. 289), "şemîm-i istihkâr" (s. 291), "şule-i bekâ" (s. 294), , "zıll-i ihtişâm" (s. 316), şemîm-i hazân" (s. 321), "bir leyl-i sefîdi mâtemîye" (s. 328), "Meşâm-1 rûh (s. 333)", "Elvân ü revâyih/ Kût-ı hevesindir" (s. 335), "leb-rîz-i sa'âdet" (s. 340), "süûd-ı şûh-ı bahâr" (s. 347), "Mahfûf-1 sükûnet" (s. 348), "kand-i ibtisâm" (s. 365), "sımâh-ı dikkât" (s. 375), "hem-reng-i teneffür" (Fikret, 2020, s. 386). Bu örneklerin sayısını arttırmak mümkündür. Burada sayllan örneklere benzer şekilde oluşturulmuş kaynak alanın duyu olmayıp kavramlar olduğu pek çok yüksek sinestezi örneğiyle şiirlerde karşılaşllmaktadır. "Şikeste reng-i sefâlet" (Fikret, 2020, s. 266) metaforunda dolaylı zincirleme aktarımın farklı bir türüyle karşılaşılmaktadır. Sefalet kavramı dokunma duyusunun görme duyusu üzerine haritalandığı sifatlar üzerine dolaylı olarak haritalanmaktadır. Düşün-duyum ifadelerini Tevfik Fikret'in ilk şiirleri arasında da yoğun bir şekilde kullandığı ancak Rübâb-ı Şikeste'de özellikle üç ya da dört unsurlu sıfat terkipleri içinde geliştirdiği tespit edilmektedir. Bu türlü zincirleme aktarımlar kavram->duyu->duyu aktarımı yapısında geliştirildiğinden esasında duyulardan duyulara aktarımın düşün-duyumun önüne geçmesine böylece dolaylı olarak güçlü sinestezinin yerini yüksek sinestezinin almasına yol açmaktadır. Bu tercih şairin duyulardan hareketle gerçeği kavrama eğiliminin en aşikâr delilidir. İlk şiirlerde sinestezi türleri arasında en çok yüksek sinestezi örnekleriyle karşılaşılırken Batı şiiriyle etkileşim, hatta bu etki sinestezinin en çok da Sembolizm etkisiyle hemen her tür sinestezi türünün şiirlerdeki kullanımı artmakta hatta sinestezinin görülmedik türlerinin keşfedilerek şiirlerde kullanılmaya başlanmasını tetiklemektedir.

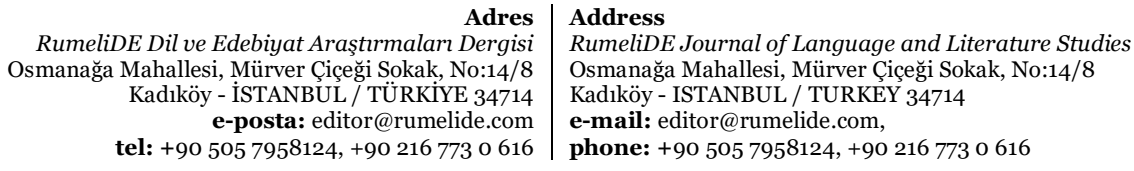


496 / RumeliDE Journal of Language and Literature Studies 2021.25 (December) "When I was listening by my eyes": literary synaesthesia in Tevfik Fikret's poetry and Tevfik Fikret as a literary synesthete / G. Nakıboğlu (pp. 468-504)

Gerek yüksek (düşün-duyum) gerekse düşük sinestezi (güçlü ve zayıf sinestezi) türündeki sinestetik ifadeler birlikte ele alındığı takdirde Rübâb-ı Şikeste’de bu tür ifadelerin diğer metaforlar arasında ne kadar öncelikli bir konuma sahip olduğu rahatça görülebilmektedir. Sinestetik metaforların, Tevfik Fikret'in şiirlerinde en sık müracaat ettiği metafor türlerinden biri olması çok önemlidir. Sinestetik metaforların duyu-duyu, duyu-duygu, duyu-kavram, kavram-duyu, duygu-duyu alanlarında genel olarak duyusal olarak kavranan gerçekliği öncelemekle kalmayıp güçlü duygusal etkilerin duyu-duyu hattı başta olmak üzere çeşitli hatlarda açı̆̆a çıkmasına yardımcı olmaktadır. Şair her hâl ve şartta, hayal ve hakikatte, duyuya ve duyusal algıya tutunmayı öncelemektedir. Şairin asıl sığınağı bu açıdan duyular ve duyusal algı evrenidir.

Duyu hattındaki aşırı yığılımın sebep olduğu kaotik ortam, ben’in duygularının şiirin geneline kaotik yayılımını sağlamaktadır. Bunun edebî göstergelerinden biri hayal ile hakikat arasındaymış gibi görünen salınımların uç noktalara taşınmasına yardımcı olan ortamın duyularla inşa edilmiş olmasıdır. Fikret’in şiirlerinde sürekli hissedilen gerginlik hâlinin her an başka bir hâle geçmeye hazırlanışın ifadesi olan titreyişlerle birleştirilmesi, şiirde söz, resim ve musikinin bir araya getirilmesiyle duyusal etkinin sinestetik metaforlara ek olarak katlanmasıyla zıt kutuplar arasındaki gerilim hatlarında çok güçlü bir kaotik enerji açığa çıkmaktadır. Bu kaotik enerji alanı bir burgaç gibi hareket ederek şiir külliyatında kimi zaman kara deliklere dönüşebilmektedir. İşte "Gayya-yı Vücûd" şiiri Rübâb-ı Şikeste'deki bu nevi kara deliklerden biridir. Tsur'un şiirde aşırı yığılımın kimi zaman aşağı seviyeye doğru bir boşaltıma sebep olabileceğine dair uyarısı (Tsur, 2007, s. 49) tüm bir şiir kitabına uygulanacak olursa sinestezinin bu kadar yoğun kullanılarak şiirlerde aşırı yüklemeye sebep olduğu durumlarda külliyattaki bazı şiirlerin bir tür boşaltım göreviyle, aşırı yı̆̆ılımın aşağı yönde bir hareketle kaotik enerjinin boşaltılması için kullanıldığını söylemek mümkündür. Bahsi geçen şiirde hep aşağıda bulunmanın veya aşă̆ıya hatta yerin altına doğru bir çekilişin söz konusu olduğu görülmektedir. "Bir çukur yerde birikmiş su"daki daimî hareket solucan, sülük ve yılanlarla sağlanmakta, bu karanlık alan gözleri bir "câzibe" merkezi gibi kendine çekmektedir, bu merkezin enerjisine şiirin öznesinin karşı gelmeye gücü yetmez, "o zulmet, o batak" "kıvranarak" "girdâb" oluşturmakta ve özneyi içine doğru çekerek batırmaya çalışmaktadır (Fikret, 2020, s. 296). Bu şiirde sinestetik metaforların sınırlı sayıda kullanılması bu boşaltım işlevi ile ilişkilidir. Benzeri boşaltım merkezlerine mukabil şiirin genelinde yükselen ve zirveyi hedefleyerek kaotik sinestetik enerjiyi her alanda biriktiren ve aşırı kaotik farklılaşmayı besleyen şiirlerin sayısı oldukça fazladır. "Berf-i Zerrîn”, “Köyün Mezarlı̆̆ında”, "Sen Olmasan”, “Belki, Hayır!..”, "Bahar-ı Mağmûm", "Süs", "Dinle, Rûhum...”, "Bir An-ı Huzûr", "Timsâl-i Cehâlet" adlı şiirler, katmerli sinesteziden çokça faydalanıldı $\breve{g}$, kaotik sinestetik enerjinin yoğun olarak biriktirildiği şiirler arasında öne çıkmaktadır. Yükselen ve alçalan imgelerin kaotik enerji yığılımına ve boşaltımına paralel bir seyir takip edip etmemesi önemli bir konudur. Genel bir bakışla yükselen ve alçalan imgelerin çoğunlukla kaotik enerji birikimine işaret edecek şekilde yükselen, kaotik enerji boşaltımına paralel olarak alçalan evsafta olduğu görülmektedir.

Nesneyi farklı duyularla birlikte algılama Tevfik Fikret'in şiirlerinde hep öne çıkmaktadır. "Sahâyif-i Hayâtımdan" şiirinde:

"Âsüman füshat-i kebûduyla,

Deniz emvâc-ı pür-sürûduyla,

Gece esrâr-ı bî-hudûduyla

Beni terhîb eder; o füshattan

Sıkılır sanki rûh-ı pür-hazerim” (Fikret, 2020, s. 271)

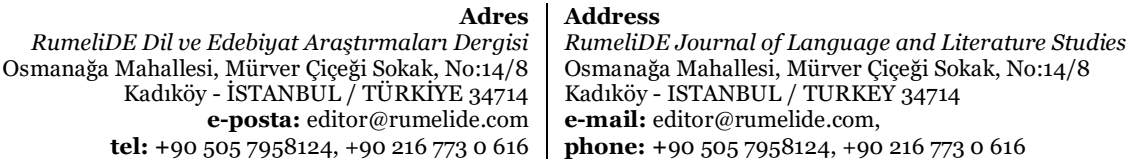

RumeliDE Dil ve Edebiyat Araştırmaları Dergis tel: +90 $5057958124,+902167730616$ 

(468-504. s.)

Gökyüzünün mavi açıklı̆̆ılla, denizin dalgalarının şarkılarıyla, gecenin sınırsız esrarıyla şaire merhaba dediği görülür. Bütün duyular bir aradadır, algı sonuna kadar açıktır ama duyuların karışması söz konusu değildir. Birlikte algılama eğilimi Fikret’in şiirlerinde genelde hep vardır ancak bu birlikte algılama bazı zamanlarda duyular arasında birbirini davete dönüştüğünde sinestetik enerji gittikçe yükselmektedir. "Köyün Mezarlığında" şiirinde olduğu gibi duygusal değerin duyuların teşvikiyle yükseltildiği şiirlerde bir anda sinestetik ifadeler olanca doğallığlyla dökülmeye başlamaktadır:

"Bütün mezarlığa sinmişti bir tarâvet-i lâl;
İşittim inledi, -ben gözlerimle dinlerken
Sükûn-ı mevki'i, âzâde fikr-i hikmetten; -
İçimde şübheli bir sesle nâgehân şu su'âl:
'Nedir hakîkati, ey sırr-ı ekber-i mescûd,
'O yanda koskoca bir kâ’inât-ı hiss ü şühûd
[...]
Cevâbı alır gibi oldum, içimde aynı sadâ” (Fikret, 2020, s. 370)

Şiirdeki öznenin arayışı 'gerçek'ten yola çıarak hakikati bulma amacına yöneliktir. Mezarlık ona bu arayışın müsebbibi soruyu sordurur. Aldığı cevap ise "esîr"dir. Ferit Devellioğlu kelimeyi "Kâinatı dolduran ve bütün cisimlere nüfûz eden, fizikçilerce, ışık, hararet ve elektrik gibi şeylere nakil vâsıtası hizmeti gördüğü farz olunan, tartısız, elâstiki ve akıcı hafif bir cisim” olarak tanımlanmaktadır (Devellioğlu, 1992, s. 279). Kaya (1995)'nın verdiği bilgiye göre Antik Yunan'dan beri kullanılan "esîr" kavramı, Grekçe "ether" kelimesinden gelmekte olup Aristo'nun ifade ettiği şekliyle "ay altı" ve "ay üstü" olarak ikiye ayrılan âlemde "ay üstü"ndeki yıldızların ebedî kaybolmayan maddesi olarak nitelendirilmektedir. Antik Yunan'dan İslâm dünyasına aktarılan esîr'in İbni Sina, "dairesel hareketin ilkesi sayılan" ve "başka herhangi bir cisimden oluşturulmayan" beşinci unsur olarak yaratma türlerinden biri olan "ibda" ile Allah tarafından yaratıldığını belirtmekte, fizikteki gelişmelerle on dokuzuncu yüzyılda tekrar ancak yeni bir şekilde gündeme gelen "esîr"in "havanın ses dalgalarını iletmesi”ne benzer şekilde "elektromanyetik dalgaları" iletmeye yaradığı düşünülmektedir (Kaya, 1995, s. 390). Fikret’in bu şiirde tüm duyularıyla aradığı gerçeğin özünü, hakikati yükselerek "esîr"de bulması önemlidir. Esîr'e duyulardan hareket eden bir yükseliş neticesinde ulaşılmaktadır. Gerçeğin onun şiirinde türlü yüzleri vardır: Sevgili olur, tabiat olur, şiir olur. O gerçeğe, şiirin öznesi sinestetik bir ifadeyle: "Soğur, donar, kırılır senden ayrılınca nazar" (Fikret, 2020, s. 317) diye seslenir. Yüksek ve zayıf sinestezi bağlamında sürekli duyulardan hareket edilmesi ya da duyulara varılması, güçlü sinestezi kapsamında duyuların çaprazlanmasıyla yükselen duyu temelli algısal yaklaşımın yücelerek gerçeği, hakikati bulma tutkusuyla esîr’i nazardan hareketle yükselerek yakalaması, duyulardan hareket ederek gerçeği ve hakikati arayışın onun şiirlerindeki somut numunesidir.

Tevfik Fikret'in Rübâb-ı Şikeste'deki şiirlerinde kaotik sinestetik enerjinin yığılımına ve aşırı kaotik farklılaşmaya en iyi örneklerden biri "Dinle, Rûhum...” (Fikret, 2020, 329) şiiridir. Şiirin başlığı işitme duyusuna bağlı fiilin ruha tahsis edilmesiyle bir yüksek sinestezi ifadesiyle başlamaktadır. "İnce, nâzik, nahîf, belki de şûh” olarak tanımlanan "Bir güzellik" terennüm edilerek görülen, işitilir kılınarak şiire başlanmakta, bu işitilir kılınan yani söze dökülen güzellikten bir "şemme-i sitem" yani sitem kokusu alınarak görme duyusundan işitme duyusuna geçilmesi ardından işitme duyusu bu kez koklama duyusuna aktarılmaktadır. Ancak sitemin nişanesi, insana yakışır bir ağlayıştan bahsedilerek güzelliğin insan olmadığına işaret edilirken bu ağlayışın mahiyeti "sada-yı şağaf" yani aşırı bir sevginin sesi ve "nefha-i rûh" yani ruhun güzel kokusu ile nitelendirilerek iki yüksek sinestetik metafor ile duyulardan

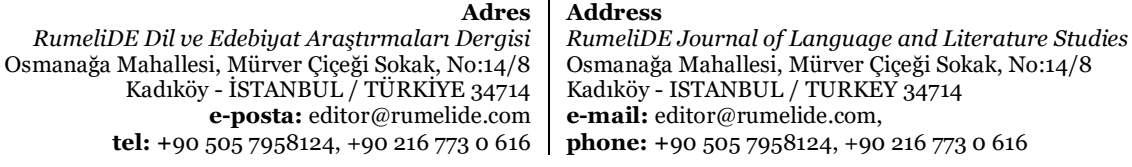


498 / RumeliDE Journal of Language and Literature Studies 2021.25 (December) "When I was listening by my eyes": literary synaesthesia in Tevfik Fikret's poetry and Tevfik Fikret as a literary synesthete / G. Nakıboğlu (pp. 468-504)

tekrar duygulara ve ruha yükselmekte böylece başlıktaki duygu ve ruhun güzelliğin duyularla ilişkilendirilmesi arasında kurulan ilişkinin tekrar duyulardan ruha ve duyguya döndürülmesiyle bir duygu-duyu-duygu döngüsü tesis edilmektedir. Bahsi geçen görme, işitme ve koklama duyuları bu alan içine yerleştirilerek alanın duyusal algı evrenini oluşturmaktadır. Şiirde sürekli tekrarlanan "Dinle, rûhum, bu rûh-ı giryânı!” mısraı bu döngüyü tamamlayarak pekiştirmektedir. Bir sonraki bölümde nağmeli öpüşün dalgasından (“mevc-i bûsiş-i nağamat”) bahsedilerek işitme duyusundaki nağme dokunma duyusundaki öpüşlere aktarılmakta ardından bu güçlü tesir dalgalar olarak görünür kılınmaktadır. Bu dalgalanma, döngüsel sinestetik şiirsel kaotik yığılım alanındaki birikimin tesirinin arttığına işaret etmektedir. Buradaki öpüşün dalgası, katmerli bir sinestetik metaforu doğurmaktadır:

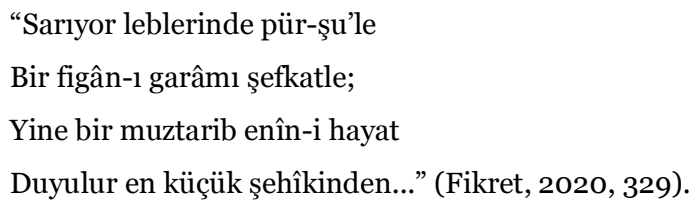

Büyük bir aşkın feryadını (işitme) alev-ışık dolu (görme) dudaklarında şefkatle saran (dokunma) "güzellik" işitme-görme-dokunma duyuları arasındaki aktarımlarla önce yakın iki duyu arasında aktarılarak güçlü bir duygusal etki yaratılmakta arkasından beklenmedik bir şekilde duyular hiyerarşisinde en alt basamağa iletilerek aşırı kaotik farklılaşmaya sebep olmaktadır. Ortaya çıkan aşırı kaotik etki yüksek sinestetik katmerli metaforun etkisini nükteli olmak bir yana duygusal olarak zirveye taşımaya yardımcı olmaktadır. Enteresan bir biçimde duyusal olarak alt bir kademeye düşüşü takip eden mısrada hayatın iniltisi işitilerek dokunma duyusu tekrar işitme duyusuna yani duyuların zirvesine sıçramakta ve "küçük şehîk" metaforuyla işitme duyusuna bağlı hıçkırık "küçük" sıfatıyla görme duyusuna aktarılmaktadır. Duyuların bu döngüsel, münavebeli ve dalgalı aktarımı ruha yönlendirilerek "Dinle, rûhum" ile başlayan mısra tekrarlanarak bir daha duyuların ruhu dalgalandırması sağlanmakta ve güçlü sinestezi yüksek sinesteziye iletilerek şiirin son bölümüne bağlanmaktadır. 'Taze ölmek üzere bir aşk' ifadesiyle aşk dokunma duyusuna düşük sinestezi ile aktarılırken dalgalar sırrını keşfe koyulup dokunma duyusu bir daha sırrı "savt-ı billûr"a bağlamak suretiyle görme duyusunun işitme duyusuna yönlendirildiği bir güçlü sinestezi ifadesiyle dolaylı bir duyusal aktarım gerçekleştirilirken güzelliğe koşan şiirin öznesi bir daha katmerli sinesteziyle yükselmektedir. Dikkat edilirse takip edilen duyu sırası en alttan en üste doğrudur. Bu kaotik sinestetik enerji birikimi öyle bir boyuta ulaşmıştır ki artık "setr" edilememektedir ve tüm bu yı̆̆ılım bir "ihtizâz” peşi sıra getirmektedir. İşte bu titreyiş şiirin öznesinin bir tür duyulardan hareketle ulaştığı güzellik karşısındaki sun’î vecd hâli özelliği arz etmektedir. Bu vecd hâli, Sembolistlerin sinesteziden hareketle tabiatta yükselerek mistik arayışlarının neticesinde ulaştıkları kendinden geçme hâlini çağrıştırmaktadır. Nitekim şiirin sonunda titreyiş yine ruha aktarılarak döngü tamamlanmakta ve şiir, şairin külliyatında daimî bir sinestetik kaotik enerji yı̆̆ılım alanı olarak yerini almaktadır.

\section{Rübâb-ı Şikeste'den sonraki şiirlerde edebî sinestezi}

Tevfik Fikret'in Rübâb-ı Şikeste'den sonraki şiirlerinde tespit edilen güçlü sinestezi türündeki ifadelerin duyular arası aktarım türlerine göre daha sık görülenden daha nadir görülene doğru oluşturulan listesi şu şekildedir:

1.Görme->işitme aktarımı: “[K]adîd bir sürü ‘Âh!”, "hande-i kebûd”, “âteşîn cerbeze”, "sadâ-yı ahen”, "Hasta bir nağme, bî-mecâl-i su'ûd, "Al sözler”, "Bir geniş 'Ooh!”, "Pür-jeng, uğulduyor yine her târ-1 âhenin” (Fikret, 2020, s. 390, 423, 428, 437, 448, 539, 549).

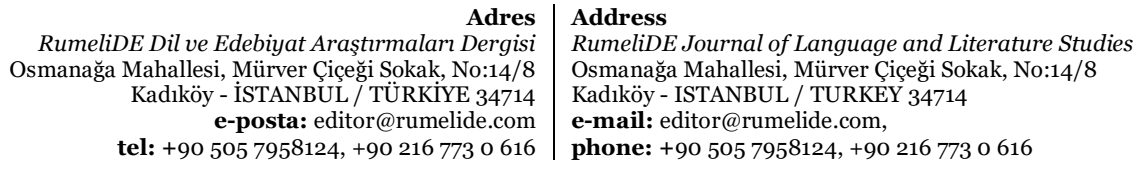



(468-504. s.)

2.İşitme->görme aktarımı: "[R]eng-i sükûnu”, "Gecenin sayha-i vedâ'iydi/ O sadâlar ki dağlar berfîn/ Tepesinden inip derin, mahfi”, "Sâmit taş", "likâ-yı samût”, "sağır duvarlar”, "bağırdın derin derin", "sesim zerd", "hutût-ı hamûş" (Fikret, 2020, s. 441, 468, 481, 539, 548, 550).

3.Dokunma->görme aktarımı: “[D]onuk bir parıltı”, "Islak nazarlarımla”, "Câmid nazar”, "soğuk çehre”, "donuk perde", "şikeste-fer" (Fikret, 2020, s. 393, 402, 432, 442, 538).

4.Görme->dokunma aktarımı: "[D]erin derin/Başlarsın ihtizazına” [titremenin dokunma duyusuna tâbi olduğu kabulüyle bu aktarım belirlenmiştir], "Nâsiye-i pür-gubârını/ Okşar bir incilâ", "göreceği /Bürûdet" (Fikret, 2020, s. 393, 435, 525).

5.Tatma->görme aktarımı: "[A]cı bir yüz ki mürtesim”, "Tatlı bir yüz”, "zehir girye” (Fikret, 2020, s. 432, $498,546)$.

6.Tatma->işitme aktarımı: “[A]cı söz”, "Acı acı hışırdarmış.” (Fikret, 2020, s. 470, 511).

7.İşitme->tatma aktarımı: "Yiyin, efendiler yiyin; bu hân-ı pür-nevâ sizin" (Fikret, 2020, s. 557) [Duyular hiyerarşisinde ters yönlü aktarım sonucu ortaya çıkan nükteli ifade].

8.Dokunma->işitme aktarımı: “[K]uru ses” (Fikret, 2020, s. 539).

9.Dokunma->görme-> işitme aktarımı (Katmerli sinestezi, dolaylı zincirleme aktarım): "Sen bak: Nasıl donup düşüyor nağmeler yere;” [donup-> düşen-> nağme] (Fikret, 2020, s. 548).

10.Görme->dokunma->tatma aktarımı (Katmerli sinestezi, dolaylı zincirleme aktarım): "Büyüklüğün biraz ağır da olsa hazmı yok zarar" (Fikret, 2020, s. 556).

Güçlü sinestezi türündeki ifadelerde en çok tercih edilen aktarım türleri görme ve işitme arasında olanlardır. Bu dönemdeki şiirlerinde şairin duyular arası aktarımda tercih ettiği türler Rübâb-ı Şikeste'dekilerle benzerdir. Servet-i Fünûn sonrasındaki dönemde sinestetik metaforların sayısının şiirlerde azalmakla birlikte kullanılmaya devam edildiği görülmektedir. Görme ve işitme gibi yakın duyular arasındaki aktarımlardan beklenen yoğun duygusal etki yine merkezdedir ancak önceki dönemdeki kadar güçlü değildir. Bu eksilen gücün telafisi “Kadîd bir sürü Âh!”, "bir geniş Oh!” gibi Servet-i Fünûn şairlerince sıkça kullanılan ünlemlerle kurulan sinestetik ifadelerle telafi edilmeye çalışılmaktadır. Duyular hiyerarşisinde geriye doğru aktarımın önceki dönemin aksine, bu dönemde nükteli ifadeler üretmek için kullanılabildiği görülmektedir. "Yiyin, efendiler yiyin; bu hân-ı pür-nevâ sizin” (Fikret, 2020, s. 557) mısraında bu tür bir ters yönlü aktarım görülmektedir. Özellikle ideolojik hicivlerde fikrî kesifleşme ardından sinestetik metaforlardan doğan nükteli mana, şiirde bir fikrî rahatlama ortamı tesis etmektedir. Duygusal olan ifadeler, şiirlerde gittikçe azalarak yerini fikre bırakmaktadır. Bu dönemde "Ey pembe Halûk'un/ Al sözleri..." (Fikret, 2020, s. 448) gibi ünlemlerle kurulu ikizleşen sinestetik ifadelerde renklerin duygusal olana geçişi hazırlamanın yanında ve gittikçe artarak ideolojik, fikrî plana hizmet etmek üzere şiire dâhil edilmeye başlandığı görülmektedir. Katmerli sinestetik metaforların dolaylı zincirleme aktarım türündekilerin birkaç örneğiyle bu dönem şiirleri arasında da karşılaşılmaktadır. Bu tür ifadelerin kaotik aşırı yığılımı besleme kapasitelerinin ise düştüğü gözlemlenmektedir.

Bu dönem şiirlerinde tespit edilen zayıf sinestezi türündeki metaforlar şunlardır: "[i்]htiyâc-ı siyâh" (Fikret, 2020, s. 390), "kalb-i şîrin" (s. 429), "ervâh-ı zî-âhenk" (s. 434), zerd ü muhtazır Eylûl” (s. 438),

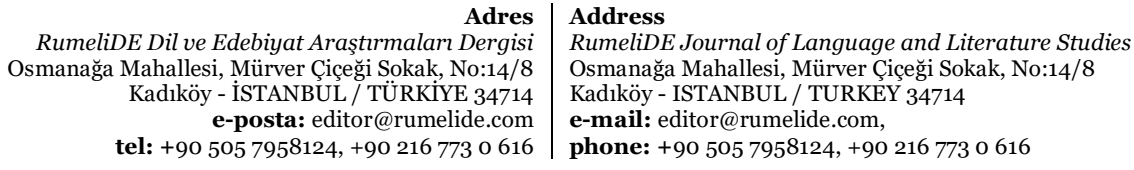


500 / RumeliDE Journal of Language and Literature Studies 2021.25 (December) "When I was listening by my eyes": literary synaesthesia in Tevfik Fikret's poetry and Tevfik Fikret as a literary synesthete / G. Nakıboğlu (pp. 468-504)

"ân-ı semen-fâm" (s. 442), "âmâl-i müzehher" (s. 447), "Ey pembe Halûk" (s. 448), "hakk-ı dırahşân" (s. 456), "müşa'şa hakîkat” (s. 462), "ümîd- bî-rengin” (s. 468), "hevl-i anîf” (s. 468), "yükselir hayat” (s. 476), "kızıl kütle-i hüsrân” (s. 481), "Pembe bir neş'e” (s. 508), "Acı hengâme-i nüşûr!” (s. 549), "yanık ser-nüvişt” (s. 550), "nâdi-i niam” (s. 556), "vicdân-ı siyâh” (Fikret, 2020, s. 562). Bu tür sinestetik metaforların sayısında bariz bir değişiklik olmamakta, duygusal olan ifadelerin yanında fikrî kavramların kullanılmaya başlaması bu dönemde önemli bir değişiklik olarak kaydedilmektedir.

Bu dönem şiirlerindeki bazı yüksek sinestezi (düşün-duyum) örnekleri şunlardır: "[B]ir sadme-i meş'ûm" (Fikret, 2020, s. 391), "cilâ-yı gurûr" (s. 398), "şü'ûn-ı reng-reng-i inşirâh u infiâliyle" (s. 430), "Uçar bâl-i hayâl açmış hakîkatlar semâsında" (s. 430), "reng-i tereddüd" (s. 432), "kanatlı bir hulyâ" (s. 433), "Acı bir hiss" (s. 437), "şûre-i nasîb" (s. 449), "zamân tünd ü mutma’in" (s. 475), "zîr-i kahrında" (s. 538), "ikbâl-i dehri tekmeleyen" (s. 543), "mahşer-i pehnâ-yı müdrikâtı" (s. 543), "muhteriz yürüyen bir fikirle seyretmiş" (s. 543) [önce zayıf sinestezi -> düşün-duyum], "ihmirâr-ı ketûm” (s. 550), "bir ebedî vasl-ı semen-fâm" (Fikret, 2020, s. 567). Tıpkı zayıf sinestezi türündeki ifadelerde olduğu gibi düşün-duyum örneklerinde de duygusal olan ifadelerin yanına fikrî kavramların eklenmeye başladığı görülmektedir. Ancak bu artışın, şairin şiirde ideolojik kayışına oranla beklenenden çok daha az olduğunu belirtmek gerekir.

"Âveng-i Şühûr"da ağustos ayına hasredilen şiirde geçen:

“Hasta bir nağme, bî-mecâl-i su'ûd,

Dökülür katre katre, eşk-âlûd

$\mathrm{Bu}$ sönen

Nefes-i vâpesîn-i mevsimdir...” (Fikret, 2020, s. 437).

Yükseğe çlkmaya gücü yetmeyen, güçsüz düşmüş, gözyaşı bulaşmış hasta bir nağme damla damla dökülmekte ve son nefesini vermekte olan mevsime ağlamaktadır. Yüksekte olmak gözle idrak edilir. Nağmenin yükselemeyip gözyaşı bulaşan katreler dökmesi, sesler çıkarmasını ifade etmektedir. Burada işitme duyusu, görme duyusu üzerine haritalanmaktadır ayrıca soyut bir kavram olan mevsim, sönen bir nesne gibi tanıtılarak zayıf bir sinestezi örneği de sergilenmektedir.

Şiirin öznesinin bu dönemde de duyular vasıtasıyla gerçeği arama hasleti sürmektedir, "Hüsn ü Ân Nedir" şiirinde bu arayış şu şekilde nitelendirilmektedir:

"Nühüfte nükte-i hilkat mi? Kim bilir?... Bu sağır

Ya kör bir âdeme bir ses, ya renk aratmaktır,

Benim o kör ve sağır şahs; o ses, o renk, o hayâl;” (Fikret, 2020, s. 543).

Bu şiirde önceki dönemde olduğu gibi duyulardan duygulara hareket etmekten ziyade duyuların gerçeği kavramaktaki faydasızlığından şikâyetle ancak yine duyulara müracaatla fikre gidilmektedir. Tevfik Fikret'in son şiiri “Kıt'a”da şiirin öznesi hâlini şu şekilde arz etmektedir:

“Artık tehî-vücûd, tehî-dil, tehî-hayâl,

Dünyâda şimdi ben dahi bir fazla sıkletim” (Fikret, 2020, s. 572).

Gerçeği dışarıda arayışın simgesi olan duyular yani beden, gerçeği içeride yani duygularda arayışın simgesi kalp, şiirdeki gerçeği arayışın simgesi hayal; hepsi boşa düşmektedir. Bu boşlukta geriye kalan sadece boşluğu ağırlığıyla işgal ettiğine inanan şiirin öznesidir. Duyuların-duyguların-hayallerin-

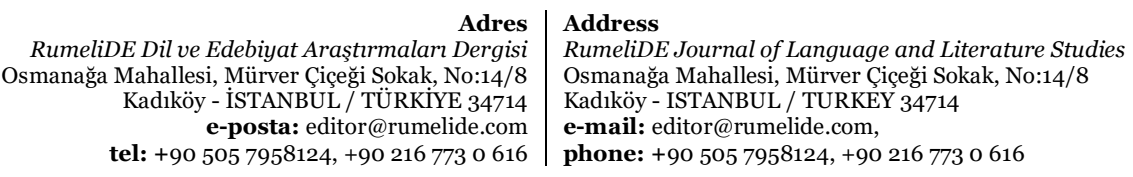


fikirlerin birlikteliği olmadan insan anlamını yitirmektedir. 'Arayış boşlukta anlamsızdır çünkü insan anlamını varlıkta bulacaktır' fikrî tezi, şairin son şiirinde manzum olarak dile getirilmektedir. Tevfik Fikret'in şiirlerinde sinesteziden hiçbir zaman sadece bir söz sanatı olarak faydalanılmaz. Her şiirde sinestezi, farklı şekillerde ve farklı işlevlerle gerçek arayışıyla ilişkilendirilmektedir. Sinestezi, gerçek arayışının farklı cephelerini kuşatacak şekilde şiirlerde geliştirilip tüm külliyata yayılmaktadır. Bu açıdan edebî sinestezinin Tevfik Fikret'in tüm şiirlerini bir arada tutan ve onları birbirine bağlayan bir edebî harç olduğu muhakkaktır.

\section{Sonuç}

Tevfik Fikret, ilk şiirlerinden başlayarak, külliyatının omurgasına bir kilit taşı misali edebî sinesteziyi yerleştirmektedir. Dönem dönem değişmekle birlikte şair, sinestezinin farklı türlerinden şiirlerini zenginleştirmekte, gerçeği arayışında, fikre ve duyguya gidişinde duyulardan hareket ettiğini belgeler mahiyette sürekli faydalanmaktadır. Bu açıdan edebî sinestezi onun şiirlerinde basit bir söz sanatı olarak kalmayıp şiiri bütünleştiren, manayı kuşatan bir çatı özelliği taşımaktadır. Özellikle görme ve işitme arasındaki duyusal aktarımların yoğunluğu, sadece söz ile musiki ve resim arasında kurmak istediği bağ perçinlemekle hatta kimi zaman tesis etmekle kalmamakta; bu duyular arasındaki aktarımlardan istifadeyle şiirde yakalamak istediği yoğun duygusal atmosferi yakalamasına da hizmet etmektedir. Servet-i Fünûn şiirinin bir imkân olarak sunduğu çoklu sıfat tamlamalarından istifadeyle şair görülmemiş, özgün sinestetik metaforlar ve imgeler üreterek edebî sinestezi alanına da önemli katkılarda bulunmaktadır. Bu minvalde katmerli sinestezinin birlikte aktarım ve dolaylı zincirleme aktarım türlerinde ürettiği sinestetik metaforların sadece bir sanat gösterisi olarak algılanması, onun şiirinde edebî sinestezinin kuşatıcı yönünün ve anlama dayalı boyutunun kaçırılmasına sebep olmaktadır. Şiirlerinde gerek yoğun şekilde farklı türde güçlü sinestetik metaforların gerek farklı türdeki sinestetik metaforların beraberce kullanılması gerekse bu metaforlara katmerli sinestetik metaforların eklenmesi, sürekli, çok yoğun bir şekilde kaotik sinestetik yığılıma sebep olmakta özellikle aşırı kaotik farklılaşma kimi zaman kendisine boşaltım alanları oluşturmaktadır. Tevfik Fikret’in şiirlerinde bilinçli şekilde kullanılan titreme ya da titreyişler, kaotik aşırı farklılaşmada oldukça önemli bir role sahiptir. $\mathrm{Bu}$ titreyişler şiirin genelinde gestaltın bozulmasını sağlamakta ve nesnelerin keskin sınırlarından kurtarılmasında görevlendirilmekte ayrıca iki unsurdan oluşan sinestetik metafora dolaylı olarak bir üçüncü duyusal bileşen eklenerek sinestetik metaforların bir üst dereceden duyular arası aktarımını temin etmektedir.

Şairin ilk şiirlerinde kullandığı sinestetik metaforlarda özellikle Klasik Türk şiirinin ve Türk Halk şiirinin yanında dolaylı olarak Batı şiirinin etkileri de görülmektedir. Rübâb-ı Şikeste döneminde baskın olan etki Batı şiiri etkisidir. Bu etki, Rübâb-ı Şikeste'den sonraki dönemde de sürmektedir. Şair her iki dönemde de Batı şiirinden sinestetik metaforlar uyarlama peşinde değildir. Tevfik Fikret, kendi üslûbunun ve devrinin imzasını taşıyan, özgün sinestetik metaforlar üretme çabasındadır. Kullandığı özgün sinestetik metaforlar, edebî sinesteziye katkıları ve şiir hayatı boyunca üslûbunun önemli bir unsuru olarak edebî sinesteziyi yoğun bir şekilde kullanması sebebiyle Tevfik Fikret’ten bir edebî sinestet olarak bahsetmek bir gereklilik hâline gelmektedir. Bir edebî sinestet olarak Tevfik Fikret, duyularla kurduğu istisnai ilişkinin belgesi mahiyetindeki şiirlerinde sinesteziyi gerçeği arayış yolculuğunda bir yükselme, keşfetme, anlamlandırma, fikre ve özellikle duyguya sıçrama aşaması olarak görmekte ve şiirinin kurucu unsurlarından biri hâline getirmektedir.

$\mathrm{Bu}$ makalede, Yeni Türk Edebiyatı alanında sinestezi üzerine yapılacak diğer çalışmalara örnek olabilecek bir yöntem sunulmaktadır. "İdeasthesia” kavramının Türkçe karşıllğı olarak "düşün-duyum”

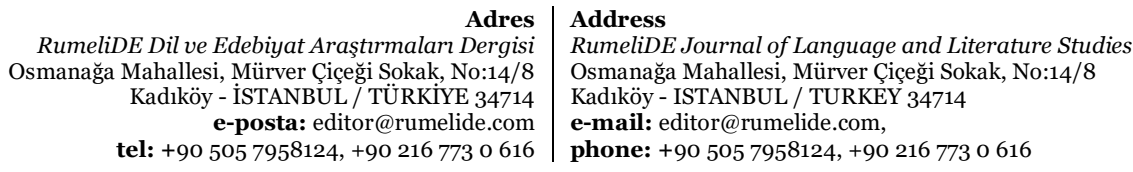


502 / RumeliDE Journal of Language and Literature Studies 2021.25 (December)

"When I was listening by my eyes": literary synaesthesia in Tevfik Fikret's poetry and Tevfik Fikret as a literary synesthete / G.

Nakıboğlu (pp. 468-504)

ifadesi önerilerek kullanılmaktadır. Ayrıca "katmerli sinestezi” yöntemi ilk kez tanımlanmakta, katmerli sinestezinin türleri "birlikte aktarım” ve "dolayl zincirleme aktarım" olarak belirlenmektedir. Katmerli sinestetik metaforların yapılan metne dayalı inceleme neticesinde Tsur'un tanımladığı "kaotik aşırı farklılaşma" temininde kullanılan yöntemlerden biri olarak değerlendirilmesi ve bu başlık altına eklenmesi teklif edilmektedir. Sinesteziye geniş ve derinlemesine bakış, Fikret’in şiirindeki çeşitli gizli kalmış bağların ve ayrıntıların ortaya çıkarılmasını ve çözümlenmesini sağlamaktadır.

\section{Kaynakça}

Abath, A. (2019, January). Merlau-Ponty and the Problem of Synaesthesia. 07.07.2021, https://www.researchgate.net/publication/333677355.

Akay, H. (1998). Cenab Şahabeddin'in Şiirleri Üzerine Stilistik Bir Araştırma (Şiir Tahlilleri). İstanbul: Kitabevi.

Akay, H. (2006). Şiir Alâmetleri. İstanbul: 3F.

Akay, H. (2020). Servet-i Fünûn Şiir Estetiği (Cenab Şahabeddin'in Gözüyle). İstanbul: Şule.

Akpınar, S. (2013, 01 01). Tevfik Fikret'in Şiirlerinde 'Titreme İmgesi'. Türkbilig(25), 75-86.

Aksan, D. (2009). Anlambilim: Anlambilim Konuları ve Türkçenin Anlambilimi (5 b.). Ankara: Engin.

Aksan, D. (2013). Şiir Dili ve Türk Şiir Dili (Dilbilim Açısından Bakış), 7. Bs. Ankara: Bilgi.

Atay, S. (2019). Tevfik Fikret: Göstergebilimsel Bir Okuma Denemesi (2 b.). Ankara: Akçağ.

Babacan, İ. (2008). Klasik Türk Şiiri'nde Sebk-i Hindî (Hint Üslûbu) (yayımlanmamış doktora tezi). Ankara: Gazi Üniversitesi Sosyal Bilimler Enstitüsü Türk Dili ve Edebiyatı Anabilim Dalı Eski Türk Edebiyatı Bilim Dalı .

Bachelard, G. (2012). Düşlemenin Poetikası. (A. Tümertekin, Çev.) İstanbul: İthaki.

Baudelaire. (2016). Kötülük Çiçekleri. (A. Necdet, Çev.) İstanbul: Ayrıntı.

Bayrak, Ö. (2013). Tevfik Fikret'in Şiirlerinde Mekân ve Algı. İstanbul: Kesit.

Berk, İ. (2019). Şiirin Çizdiği: Edebiyat ve Şiir Üzerine Yazılar. (Y. Armağan, Dü.) İstanbul: YKY.

Budak, S. (2009). Psikoloji Sözlüğü. Ankara: Bilim ve Sanat.

Burrows, F. E. (2012). Words of Shape and Shade: Synaesthesia in the Poetry and Poetics of the Early Twentieth Century (Doctor of Philosophy Thesis). Australia: The University of Western Australia.

Cazeaux, C. (2002). Metaphor and the Categorization of the Senses. Metaphor and Symbol, 17(1), 3-26.

Cebeci, O. (2019). Metafor ve Şiir Dilinin Yapısal Özellikleri (2 b.). İstanbul: İthaki.

Cevizci, A. (2011). Felsefe Sözlüğü. İstanbul: Say.

Cytowic, R. E. (1995, 07). Synesthesia: Phenomenology and Neuropsychology A Review of Current Knowledge. Psyche, 2(10).

Çelik, F. (2018). Romantik ve Sembolist Şiirde Sinestezi: Edebi Metinleri Duyulardan Hareketle Bir Okuma Denemesi (yayımlanmamış doktora tezi). Eskişehir: Eskişehir Osmangazi Üniversitesi Sosyal Bilimler Enstitüsü Karşılaştırmalı Edebiyat Anabilim Dalı .

Day, S. (1996, 7). Synaesthesia and Synaesthetic Metaphors. Psyche, 2(32).

Demir, G. Y. (2015). Çevirenin Önsözü: Metafora Dönüş. G. Lakoff, \& M. Johnson içinde, Metaforlar: Hayat, Anlam ve Dil (G. Y. Demir, Çev., 2 b., s. 9-18). İstanbul: İthaki Yayınları.

Demir, M. (2009). Batı 'Metafor'u ve Doğu 'İstiare'sinin Mukayeseli Olarak İncelenmesi. Türkbilig(18), 64-90.

Deroy, O., \& Spence, C. (2013, 10 14). Training, hypnosis, and drugs: artificial synaesthesia, or artificial paradises? Frontiers in Psychology, 4(660), 1-15.

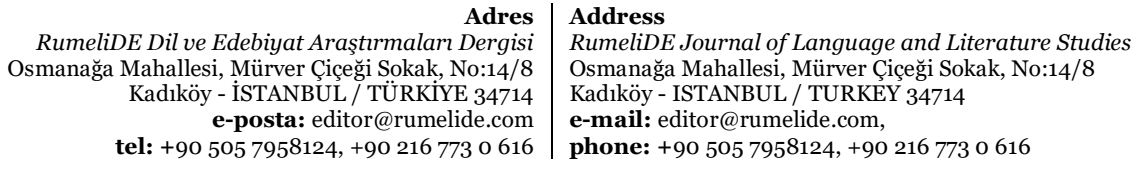


Devellioğlu, F. (1992). Osmanlıca-Türkçe Ansiklopedik Lûgat (10 b.). Ankara: Aydın.

Dilçin, C. (2009). Örneklerle Türk Şiir Bilgisi, 9. Bs. Ankara: Türk Dil Kurumu.

Downey, J. E. (1912, o8 25). Literary Synesthesia. The Journal of Philosophy, Psychology and Scientific Methods, 9(18), 490-498. 10.08.2020, http://www.jstor.com/stable/2012445.

Elmas, M. Ş. (2010). İkinci Yeni Şiiri Üzeinde Anlambilimsel Bir İnceleme (yayımlanmamış yüksek lisans tezi). İstanbul: İstanbul Üniversitesi Sosyal Bilimler Enstitüsü Türk Dili ve Edebiyatı Anabilim Dalı Yeni Türk Dili Bilim Dalı.

Fikret, T. (t.y.). Rübâb-1 Şikeste. İstanbul: Karbon Kitaplar.

Fikret, T. (2020). Tevfik Fikret: Bütün Şiirleri (3 b.). (İ. Parlatır, \& N. Çetin, Dü) Ankara: Türk Dil Kurumu.

Gülseren, Ş. (2001). Eşduyum (Empati): Tanımı ve Kullanımı Üzerine Bir Gözden Geçirme. Türk Psikiyatri Dergisi, 12(2), 133-145.

Harris, S. J. (2019). Sinestezi. (G. Acar, Çev.) Ankara: Panama.

Huyugüzel, Ö. F. (2018). Eleştiri Terimleri Sözlüğü. İstanbul: Dergâh.

Jürgens, U., \& Nikolic, D. (2012). İdeasthesia: Conceptual Processes Assign Similar Colurs to Similar Shapes. Translational Neuroscience, 3(1), 22-27.

Kaplan, M. (2007). Tevfik Fikret: Devir-Şahsiyet-Eser, 10. Bs. İstanbul: Dergâh.

Karaca, A. (2005). İkinci Yeni Poetikası. Ankara: Hece.

Karataş, T. (2011). Ansiklopedik Edebiyat Terimleri Sözlüğü. İstanbul: Sütun.

Kaya, M. (1995). Esîr. Türkiye Diyanet Vakfı İslâm Ansiklopedisi (Cilt 11, s. 390). içinde İstanbul: TDV.

Kefeli, E. (2009). Metinlerle Batı Edebiyatı Akımları (2 b.). İstanbul: Akademik Kitaplar.

Kumcu, A. (2021, October 3). Linguistic Synesthesia in Turkish: A Corpus-based Study of Crossmodal Directionality. Metaphor and Symbol, 36(4), 241-255.

https://doi.org/10.1080/10926488.2021.1921557

Lakoff, G., \& Johnson, M. (2015). Metaforlar: Hayat, Anlam ve Dil (2 b.). (G. Y. Demir, Çev.) İstanbul.

Martino, G., \& Marks, E. (2001, April). Synesthesia: Strong and Weak. Current Directions in Psychological Science, 10(2), 61-65. https://doi.org/10.1111.1467-8721.0016.

Merleau-Ponty. (2015). Algının Fenomenolojisi, Göz ve Tin, Görünür ve Görünmez. (E. Şan, Çev.) İstanbul: Say.

Merleau-Ponty, M. (2014). Algılanan Dünya: Sohbetler (4 b.). (Ö. Aygün, Çev.) İstanbul: Metis.

Moore, J. (2017). Sinestezya (11. Baskı b.). (E. Kaptan, Çev.) İstanbul: Aprıl.

Morsunbul, H. (2006). Resim ve Şiir İlişkisi Işığında İlhan Berk Sanatı (yayımlanmamış yüksek lisans tezi). Eskişehir: Anadolu Üniversitesi Sosyal Bilimler Enstitüsü Güzel Sanatlar Anabilim Dalı.

Mum, C. (2006). Sebk-i Hindî'de Beyit Yapısı, Paradoksal İmajlar ve Çoklu Duyulama. H. Aynur, M. Çakır, \& H. Koncu içinde, Sözde ve Anlamda Farklılaşma: Sebk-i Hindî (s. 108-141). İstanbul: Turkuvaz.

Özmen, K. (2016). Modern Türk Şiirinde Fransız Etkileri. İstanbul: Sel.

Parlatır, İ. (2012). Tevfik Fikret (2 b.). Ankara: Akçağ.

Ramachandran, V., \& Hubbard, E. (2001). Synaesthesia- A Window into Perception, Thought and Language. Journal of Consciousness Studies, 8(12), 3-34.

Rimbaud, A. (1968). Sesliler. İ. Berk içinde, Dünya Edebiyatında Aşk Şiirleri: Evvel Zaman Aşkları, Yakın Zaman Aşkları, Şimdiki Zaman Aşkları (İ. Berk, Çev., s. 28). İstanbul: Varlık.

Rimbaud, A. (2001). Illuminations: Cehennemde Bir Mevsim. Çağdaş Matbaacılık.

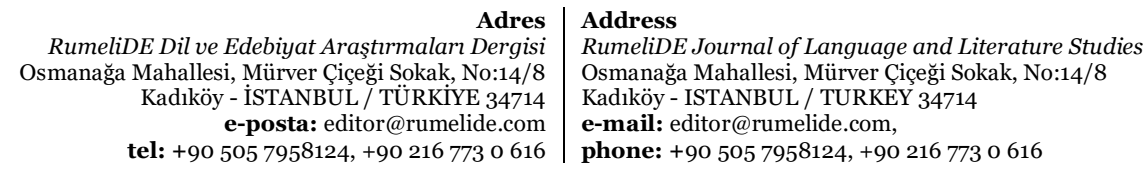


504 / RumeliDE Journal of Language and Literature Studies 2021.25 (December)

"When I was listening by my eyes": literary synaesthesia in Tevfik Fikret's poetry and Tevfik Fikret as a literary synesthete / G.

Nakıboğlu (pp. 468-504)

Sacks, O. (2014). Müzikofili: Müzik ve Beyin Öyküleri, 2. Baskı. (B. Kovulmaz, Çev.) İstanbul: YKY.

Shen, Y. (1997). Cognitive constraints on poetic figures. Cognitive Linguistics, 8(1), 33-71. https://doi.org/10.1515/cogl.1997.8.1.33.

Sivri, M., \& Çelik Özkan, F. (2020). Arthur Rimbaud'un "Sesliler" Şiirinde Duyular ve Yaratıcı Bilinç. Yeni Türk Edebiyatı Araştırmaları, 12(23), 95-116. https://doi.org/10.26517/ytea.421

Şahan, K. (2020). Şiirde Derin Yapı Metafor: Modern Türk Şiiri Üzerine Bir İnceleme. Ankara: Ebabil.

Şahin, S. (2006). Tevfik Fikret, Parnasizm, Servet-i Fünûn ve Resim ile Şiir İlişkisi . Biyografya 7 Tevfik Fikret (s. 137-156). içinde İstanbul: Bağlam Yayıncılık.

Türk Dil Kurumu. (1988). Türkçe Sözlük 1-2 (8 b.). Ankara: Türk Dil Kurumu.

Tanalp, R. (tarih yok). 10.06. 2020, http://cdn.istanbul.edu.tr/FileHandler2.ashx?f=duyufizyolojisi.pdf.

Tanpınar, A. H. (1997). 19 uncu Asır Türk Edebiyatı Tarihi (8 b.). İstanbul: Çağlayan.

Tsur, R. (2007, Spring). Issues in Literary Synaesthesia. Style, 41(1), 30-51. 22.09.2021, https://www.jstor.org/stable/10.5325/style.41.1.30.

Uçan, H. (2018). Batı Şiiri ve Tevfik Fİkret: Tevfik Fikret ve Metinlerarası İlişkiler. İstanbul: İz.

Ullmann, S. D. (1945, September). Romanticism and Synesthesia: A Comparative Study of Sense Transfer in Keats and Byron. PMLA, 6o(3), 811-827.

Wellek, R., \& Warren, A. (2011). Edebiyat Teorisi. (Ö. F. Huyugüzel, Çev.) İstanbul: Dergâh.

Werning, M., Fleischhauer, J., \& Beşeoğlu, H. (2006). The Cognitive Accessibility of Synaesthetic Metaphors. R. Sun, \& N. Miyake içinde, Proceedings of The Twenty Eight Annual Conference of The Cognitive Science Society (s. 2365-2370). London: Lawrence Erlbaum Associates.

Wheeler, K. L. (2013). Understanding Synesthesia and Impact for Learning. California, USA: School of Education and Counseling Psychology Dominican University of California (master of science in special education).

Winter, B. (2019). Synaesthetic Metaphors are neither synesthetic nor metaphorical. L. Speed, C. O'Meara, L. S. Roque, \& A. Majid içinde, Perceptin Metaphors (s. 105-126). USA: John Benjaminns Publishing Company. https://doi.org/10.1075/celcr.19.o6win

Ylkmış, S. (2020, Ekim). Empati Dili. Türk Dili, 69(826), 92-101.

$\mathrm{Yu}, \mathrm{N}$. (2003). Synesthetic Metaphor: A Cognitive Perspective. Journal of Literary Semantics, 32(1), 1934. https://doi.org/10.1515/jlse.2003.001

$\mathrm{Yu}, \mathrm{X}$. (2012, November). On The Study Of Synesthesia and Synesthetic Metaphor. Journal of Language Teaching and Research, 3(6), 1284-1289. https://doi.org/10.4304/jltr.3.6.1284-1289

Zawislawska, M. A. (2016). Synamet- A microcorpus of Synesthetic Metaphors. Preliminary Premises of the Description of Metaphor in Discourse. Cognitive Studies(16), 107-118. https://doi.org/10.11649/cs.2016.010

RumeliDE Dil ve Edebiyat Arastirmalar Deres

RumeliDE Dil ve Edebiyat Araşttrmaları Dergisi Osmanağa Mahallesi, Mürver Çiçeği Sokak, No:14/8 Kadıköy - ÍSTANBUL / TÜRKIYE 34714 e-posta: editor@rumelide.com tel: +90 $5057958124,+902167730616$
Address

RumeliDE Journal of Language and Literature Studies

Osmanağa Mahallesi, Mürver Çiçeği Sokak, No:14/8

Kadıköy - ISTANBUL / TURKEY 34714

e-mail: editor@rumelide.com,

phone: +90 5057958124, +90 2167730616 